\title{
Perceptions of Corruption in Ukraine: Are They Correct?
}

\author{
Inna Č́ábelková \\ CERGE-EI
}

\begin{abstract}
This paper discusses the issue of perceptions and their influence on economic processes focusing on corruption perception. The higher the perceived corruption in an organization is, the more probable it is that a person dealing with that organization would offer a bribe, thus supporting corruption. Since corruption perceptions are rarely based on actual experience, they might describe reality inadequately. In this case the sources of corruption perceptions might facilitate or diminish the actual corruption level. This paper provides an empirical analysis of the association between corruption perception and the willingness to give bribes as well as the influence of different sources of corruption on corruption perception in Ukraine.

\section{Abstrakt}

Článek se zabývá problematikou vnímání korupce a jeho vlivu na ekonomické procesy. Vnímání korupce je zřídkakdy založeno na osobních zkušenostech a proto nemusí odpovídat realitě. Čím více si však lidé myslí o určité organizaci, že je zkorumpovaná, tím pravděpodobnější je, že nabídnou úplatek a naopak. Zdroje informací o korupci, které formují vnímání korupce, tak mohou k rozvoji korupce jak přispívat, tak ho brzdit. Článek analyzuje průzkum veřejného mínění na Ukrajině za účelem zjištění vlivu různých zdrojů informací o korupci na vnímání korupce a souvislosti mezi vnímáním korupce a ochotou dát úplatek.
\end{abstract}

JEL: Z13, C31, C35, D73

Keywords: corruption perceptions, corruption, simultaneous system estimation.

I would like to thank Prof. Hanousek for providing me with the basis version of the TSP program and for help and encouragement in the process of writing this paper. I would like to thank Prof. Filer and Prof. Kmenta for useful comments and suggestions. I thank the director of the Kiev International Institute of Sociology for the access to the data I use in this paper. 


\section{Introduction}

Many factors that facilitate corruption are discussed in economic literature. Scholars often mention the lack of adequate legislation, poor law enforcement, cultural prerequisites, the lack of incentive for the government to fight corruption, low wages for state officials, etc. (see Mauro, 1996, Tanzi, 1998, Rose-Ackerman 1997, Hofstede, 1991, Andvig, 1991). One thing is often forgotten, or, at least, not articulated clearly enough: corruption might be influenced by the perception of corruption. Perception itself is the product of the sources of information about corruption, and may describe the level of corruption inadequately. This paper provides an empirical analysis of the influence of the sources of information about corruption on corruption perceptions and the association between perceptions and the willingness of people to give bribes in Ukraine.

Corruption perceptions may substantially influence the level of corruption. In some cases corruption perceptions can reinforce corruption. High corruption perceptions make people believe that they have to pay bribes, and the officials to think that there is nothing wrong with accepting them. Perceiving that many people pay bribes, customers are much more sure that a bribe will be accepted and much less sure that a matter may be solved without a bribe. Believing that everybody takes bribes, officials lose the fear of being punished for receiving bribes. If each person believes everybody else to be corrupt, corruption becomes a part of the culture: customers think that they will offend officials by not offering a bribe, and officials who do not accept bribes are seen as cultural outliers. On the other hand, corruption perceptions can also diminish corruption. In countries with strong law enforcement, corruption perceptions work as a signal that switches on the law enforcing machine, which eventually limits corruption. Such a path of events is, however, contingent on several factors. The first is the availability of resources to fight corruption. If corruption is widespread, the police are more likely to encounter a lack of resources to investigate every act of corruption. The second is the actual, as opposed to the pretended, willingness to fight corruption. If 
corruption becomes a part of the culture, it is very difficult to eliminate it even if the best legislation is in place and there is sufficient perception that people are corrupt.

Corruption perceptions might substantially influence the level of corruption, but where do the perceptions come from? Obviously, once having paid a bribe, a customer will be surer that the officials are corrupt. Similarly, once having accepted a bribe, the officials are more certain that the organization is corrupt. Corruption perceptions, thus, are a product of corruption itself. The problem is that corruption is not the only factor that determines the perceptions.

People learn about corruption from different sources. One of the most reliable is the actual experience of corruption. However, actual contacts between officials and the public are quite rare. Thus, few people can rely on personal experience. People speak about corruption with other people or they hear about corruption through mass media (for the proportion of respondents who use different sources of information about corruption, see Table 1). The information gained in these ways might be incomplete, politically colored or subjectively described. Looking for a big story or being paid by politicians, journalists may tend to exaggerate stories about corruption. For the same reasons, publishers may choose to publish proportionally more articles on corruption than the phenomenon deserves. However, in fear of being punished for uncovering the acts or actual level of corruption, the mass media may also avoid publishing materials on corruption. So, opinions on corruption formed by the mass media may be far from reality. Similarly, information about corruption learned from friends or strangers is also subjective. It is invariably affected by the temperament of the teller and, possibly, his/her imagination.

Corruption perceptions are a very complex phenomenon, which may substantially influence the level of corruption. This paper provides an econometric study of corruption perceptions, how they are formed, and their influence on the willingness of the population to give bribes in Ukraine.

The rest of the paper is organized as follows. The first section provides a brief literature 
review of the theoretical studies about the role of perceptions in different sectors of an economy, and, in particular, on the influence of the perception on the spread of corruption. The second section describes the data. I use the data collected in a survey performed by the Kiev International Institute of Sociology in 1998. The third section describes the methodology for the empirical analysis. The fourth section presents the results. The fifth section concludes.

\section{Do perceptions matter? A short literature survey}

The role of beliefs and perceptions influencing economic processes is recognized in many fields of economics. Krugman (1991) discusses the role of expectations in determining the equilibrium in a simple model of international trade. Matsuyama (1991) shows that selffulfilling prophecies are an important determinant of the equilibrium in a model of industrialization. Farrell and Saloner (1986) demonstrate that self-fulfilling prophecies can influence the equilibrium in a model of technology adoption. In the field of macroeconomics, expectations are important especially in search models, where the profitability of participating in economic activities depends on how many other agents participate (see Diamond and Fudenberg, 1978, and Howitt and McAfee, 1988).

In all the above studies several eqiuilibria are possible. The choice of equilibrium depends substantially on the agents' expectations and history. The main idea can be most easily described by a model proposed by Krugman (1991). In his setting there are two countries opening up trade and two goods produced: a constant returns to scale (CRS) good and an increasing returns to scale (IRS) good. The assumptions are such that if many people work in the CRS sector, the advantages of the IRS sector are not realized and it is more profitable to work in the CRS sector. If more than a certain number of people switch to the IRS sector, it starts to be more profitable to work there because of increasing returns to scale. 
Before trade is opened both goods are produced in both countries. When the countries start to trade, natural specialization occurs. Which good will be produced in which country depends on the comparative advantage in its production, which in its turn, depends on how many people work there. In this situation if one expects that the rest of the population will choose to work in the IRS sector, it is profitable for him/her to switch to this sector (contingent on the prevalent production of the other country). If, on the other hand, everybody expects that others will stay working in the CRS sector, it would be more profitable for them to stay in that sector as well. The dynamics of the transition from one sector to another depends on both expectations and the history of employment before trade was open ${ }^{1}$.

A similar line of argument is employed in multiple equilibria models of corruption. To my knowledge, the most general model in this field was proposed by Schelling (1973). In his paper a population of state officials decides whether to accept bribes or to stay honest, depending on the utility they gain. Schelling plots the utilities of corrupt and honest officials as a function of how many of other officials are corrupt. He argues that the utility of an honest official decreases with an increase in the number of corrupt officials. The decline is attributed to the dangerous effect of corruption on the economy as a whole. The utility of a corrupt official is bell-shaped: it increases with the number of corrupt officials when relatively few officials are corrupt, reaches its maximum and starts decreasing when the number of corrupt officials exceeds a certain point. When only a few officials are corrupt, as the number of people accepting bribes increases, the feeling of guilt from corruption, fear of loss of reputation, and fear of actual punishment decrease (for similar argumentation see also Akerlof, 1980) and the actual utility is larger. When the number of corrupt officials reaches a

\footnotetext{
${ }^{1}$ All the articles mentioned above do not explicitly model the sources of beliefs and the paths of their changes. More detailed analyses of these issues are proposed in game theory which utilizes a Bayesian updating mechanism or in more modern fields of economics such as case-based decision making (Gilboa and Schmeidler, 1995) or evolutionary game theory.
} 
certain point the utility of one corrupt official starts decreasing, because corruption becomes a less scarce good and bribers are willing to pay them less.

Another important assumption of Schelling's model is that the utility of an honest official is greater than the utility of a corrupt official if few officials are corrupt, and less if almost all the officials are corrupt. Under these assumptions three equilibria are possible: there is no corruption (if all officials are honest it does not pay to become corrupt), all of the officials are corrupt (if all the officials are corrupt it does not pay to become honest), or — the equilibrium in between — some of the officials are corrupt, the others are not and the utility of both corrupt and non-corrupt officials are equal. The last equilibrium is unstable: a small external shock to perceptions of corruption may put the economy into a basin of attraction to one of the other two equilibria. In this model, which equilibrium is chosen depends substantially on the beliefs of officials about the corruptness of others. Schelling did not provide explicit dynamic computations of the transitory paths.

A more specific dynamic model of corruption was developed by Lui (1986) who used the overlapping generations framework and under certain assumptions calculated the expected profitability of corruption for both the old and the young generation. The mathematics and arguments of the paper are too complicated to be discussed here in detail. It is enough to say that in this model at least two stationary states are possible: a more or a less corrupt one. For the given preferences of the agents, the regulatory environment, and law enforcement, two very different levels of corruption are possible.

Lui (1986) did not work explicitly with one's beliefs about the corruptness of others and did not provide an explanation why one equilibrium is chosen rather than the other. Beliefs were incorporated into the overlapping generations framework by Sah (1987). Sah assumed that bureaucrats and citizens start with a subjective probability distribution about how likely it is that the agent they will meet in a transaction is corrupt. Depending on the distribution they calculate how profitable it is to engage in corrupt and non-corrupt 
transactions. After each period the beliefs are updated according to the Bayesian rule. Similarly to Lui, Sah showed that several steady state levels of corruption are possible, depending on the initial subjective probability of meeting a corrupt official, i.e. corruption perception. The important feature of Sah's model is that it allows one to discuss discrepancies between corruption perceptions and actual corruption occurrence, their impact on the dynamics of the model and the equilibrium chosen.

This paper can be viewed as an empirical parallel to Sah's paper. Here I also analyze the discrepancy between beliefs about the corruption of the state officials and the actual level of corruption. Further, similar to Sah, I look at the influence of beliefs on the willingness of the citizens to initiate corrupt acts.

\section{The data}

Data were collected by the Kiev International Institute of Sociology in a survey named "Questions on National Integrity" in 1998. In this survey 2600 respondents from most of the regions of Ukraine were asked to assess the level of corruptness of state and non-state institutions, to reveal their opinions on the effectiveness of some methods and means to fight corruption, the sources of the information about corruption and the reliability of the sources. The respondents were chosen in a purely random fashion so that all adult citizens had an equal chance to be interviewed ${ }^{2} .475$ respondents, i.e. $19 \%$ of intended sample, refused to be

\footnotetext{
${ }^{2}$ The selection of respondents was done in several stages. First, towns and villages were chosen at random so that the probability of inclusion of a village or town into the survey is proportional to the number of residents in the village or town. Then according to the same principle post offices, streets, buildings and, finally, the respondents were chosen. The interviewers then informed the potential respondents about the survey and visited them at their homes. It was not permitted to replace the respondent who denied to be interviewed with somebody else.
} 
interviewed. The most frequent problem was that the respondents did not open the doors of their homes to the interviewers. Other potential respondents opened their doors but refused to answer the questions. The resulting size of the sample is 2104 respondents. The resulting sample is $20 \%$ smaller than intended.

In order to find out whether the sample is still representative under these conditions, the Kiev International Institute of Sociology compared the gender, age and education of the resulting sample to the results of a demographic survey of the Ukrainian population done in 1989 (more contemporary data are not reliable since they are based on estimates). In none of these categories did the error exceed 5\% (Questions of National Integrity, 1998). The sample can thus be considered representative.

The data I use in this paper are a part of the whole survey dataset. In particular I use the following:

- respondents' corruption perceptions in seventeen different institutions (for the list of institutions see Table 2),

- the number of respondents' visits to these institutions during the twelve months before the survey,

- the source of respondents' information about corruption (press, TV, radio, friends, strangers, and personal experience),

- the degree of the respondents' trust of the mass media,

- respondents' opinion on how well the government fights corruption,

- respondents' willingness to give bribes,

- occupation, age and gender of the respondents, and

- the size of respondents' town of residence. 
Respondents' corruption perception and the number of visits to the institutions are the only institution-specific variables present in the analysis. For a brief description of all the data variables see Table 3. For the wordings of the questions see Appendix 3.

\section{Specification}

This section is organised as follows. The first two subsections provide theoretical argumentation for the choice of explanatory variables for the two equations I estimate: the corruption perception equation and willingness-to-give-bribe equation. The third subsection discusses data problems and data transformations. The forth subsection is devoted to the method of estimation.

\subsection{Willingness-to-give-bribe-equation}

The decision on whether to give bribes depends on the expected benefits from the bribery net of possible losses ${ }^{3}$. Mathematically speaking,

$W G B=F(p \times B e n-q \times P u n)$

where

$W G B$ is the willingness to give bribe,

$F \quad$ is an increasing function,

$p \quad$ is the perceived probability that the bribe is accepted,

Ben is the expected benefits if the bribe is accepted (including the probability that the benefits are indeed realized),

Pun is the degree of punishment for corruption, and

\footnotetext{
${ }^{3}$ I abstract here from the losses of effort employed when offering bribes.
} 
$q \quad$ is the probability that the punishment is implemented ${ }^{4}$.

The perceived probability that a bribe is accepted in a certain institution may be well represented by the perception of corruption in the institution ${ }^{5}$. If one perceives an institution to be very corrupt, one is much more prepared to give a bribe even if one does not require any illegal operations, and that the bribe will be accepted for the unofficial procedure in return. I use corruption perception as a proxy for the perceived probability that the bribe would be accepted or required.

The benefits from corruption are different in nature as well as extent in different institutions. The benefits from corruption in, for example, tax inspection, are completely different than those at schools or medical establishments. Sometimes, it is impossible to find the monetary approximation of some benefits such as additional doctor care, which may save the patient's life. In order to address this non-homogeneity of benefits, I conduct an analysis for different institutions separately rather than aggregating the data across institutions.

The perceived possible punishment if the bribe is not accepted may be of two kinds: legislative and social. The legislative type of punishment, together with the probability that it is implemented, is proxied by the perceived inaction of the government in fighting corruption $^{6}$. Social punishment represents the possible resentment of neighbors toward corrupt

\footnotetext{
${ }^{4}$ Theoretically one should distinguish between two possible probabilities of punishment depending on whether the official accepts or rejects the bribe. However, in the case of Ukraine both of these probabilities are very low, thus, one can assume them to be equal and the formula above makes sense.

${ }^{5}$ Here I leave out the problem of facing one official many times and deriving the relevant corruption perception from the interactions with a certain official rather than the whole institution. The data allow me to do so since the number of visits to the institutions in question is often rather small, and thus the probability that the respondents would rely on their experience with one particular official is small as well.

${ }^{6}$ Note that the question in the questionnaire about the willingness of the government to fight corruption is formulated in a way that addresses the actual deeds of the government rather than legislative acts that are never
} 
behavior. It substantially depends on whether corruption is perceived to be an evil in the population, and on the particular sub-culture present in the population group (see peasant example below). In any case, a major prerequisite for social punishment is the extent to which people in a community know each other. In the big city, where people do not know each other very much, social punishment is virtually impossible: one does not care about antipathy of the person one does not know well. Thus, expected punishment is proxied by both the perceived willingness of the government to fight corruption and, partially, the size of the town the respondent lives in.

When estimating the relationship above I also control for the individual characteristics of respondents, namely occupation, size of the respondent's town of residence, age and gender $^{7}$. Below I briefly explain why I consider these characteristics important.

Occupation influences cultural environment of the respondent and his/her attitude to corruption. While the influence of the attitude to corruption on the willingness to give bribes is quite obvious, I will focus more on culture issues. Take for example peasants. It is well established in the anthropological literature that peasants usually have their own culture, which distinguishes them from people of other occupations. According to Harrison (1985), peasants are usually people who believe that everything in this world is of the limited quantities: the land they work on cannot be increased, and they are not able to collect more than a certain amount of harvest per year. The only way they can make themselves better off is to try to take a bigger part from the constant social cake. One can argue that having such a psychological background they perceive the corruption of the state officials as an opportunity to get more from the cake.

\footnotetext{
enforced.

${ }^{7}$ One can argue that education of the respondents should be included too. On the other hand the impact of education is already partially included through age and occupations of the respondents so I decided to leave education out so that it can be used in correction equations (see correction equations section).
} 
Occupation may be also interconnected with the profitability of corruption, and the frequency of facing it, which in turn affects the willingness to give bribes. Businessmen, for example, are much more likely to give bribes. They have to communicate with state officials much more often than the rest of the population and usually have limited time to solve problems. Businessmen are also the people for whom bribery is the most profitable.

Another factor I control for is the size of the respondents' towns of residence. For example for businessmen it makes a great difference if a bribe is given in a small town for the monopolistic position on the small local market than to bribe the state official in a big city for a substantial share of national market.

Restating the above verbal arguments algebraically, one arrives at the following relationship:

$B=f_{1}\left(C_{i}, I, T, O, A, G\right)+e_{1}$

Where

Dependent variable: perceived necessity to pay bribe $(B)$

Independent variables:

corruption perception in institution $i\left(C_{i}\right)$

perceived inactiveness of the government in fighting corruption $(I)$

size of the respondent's town of residence $(T)$

occupational dummies $(O)$

respondent's age $(A)$ and gender $(G)$

\subsection{Corruption perception equation}


Perception of corruption, as any other kind of perception, is very much influenced by two factors. The first is the information one receives about the phenomenon. The second is the way the individual processes the information and makes conclusions. The information received may be intentionally or unintentionally biased by the source of information. The way the individual processes the information substantially depends on his/her individual characteristics. Below I discuss both of the factors in relation to corruption perception and form corruption perception equations.

The most reliable source of information that influences one's perception of corruption in a certain institution is the actual experience when dealing with the officials from the relevant institution. Here a person may face blatant demand of bribe, intentional slowing down bureaucratic procedures in a hope for a bribe, or, to the contrary, smooth and easy administering of his/her request. Thus, one could argue that the more a person visits certain institution, the more accurate his/her perception of corruption in this institution becomes.

While frequency of visits is very important determinant of corruption perception, in some cases it may be misleading. The respondent might have to go to the institution many times just because he/she had a misfortune to meet a corrupt official (who slowed down the bureaucratic procedures in order to be able to ask for a bribe) the first time he/she went there. Yet, there are very few people in the sample who have visited the institutions more than one time during a year before a survey, so I can exclude the last possibility from the analysis.

Unfortunately, few people go to state institutions often enough to be able to form their perception of corruption solely on their personal experience. People learn about corruption in many ways. They read stories about it in press, listen to the stories on radio, watch TV programs. They share the information with their friends, relatives, or strangers on the streets (for the proportions of the respondents that use the different sources of information about corruption see table 1). All of these sources are likely to provide colored information about corruption. 
The most controversial source of information about corruption are the mass media. It may want to suppress the issue of corruption in a fear of being punished by the relevant state officials. It may publish politically colored articles on corruption. Or, it may publish more articles on corruption than the phenomenon deserves just in order to publish big stories and, thus, increase its audience. Sometimes, the audience can distinguish between these kinds of articles, but often not. In any case, the influence of the mass media on a person's corruption perception depends on the extent of his/her trust in the mass media.

The other sources of information are friends, relatives and strangers. While the extent of trust might be also important here, the contacts between the giver and the receiver of information are closer than in the case of the mass media and, except strangers, one can better estimate trustfulness of the information.

Besides sources of information the individual characteristics of the respondents such as age, gender and occupation might be important determinants of one's perception of corruption. People of very old or young age might not be much interested corruption since they have more important things to care about. In addition, they are likely not to face corruption as often as the population of working age. Thus, their perception of corruption is likely to be much more vague and unclear.

Men and women might perceive corruption differently since they have different roles in the society. Women, who care for children and, thus, have to visit schools and universities often might have a different perception of corruption than men, who know about it only from TV program (usually he has much more time to watch them), and press.

People who hold intellectually demanding positions are more likely to exercise critical thinking and develop their own opinion on corruption, rather than absorbing the opinion of the people with whom they frequently communicate with, or of the producers of TV and radio programs. In addition, an occupation, which imposes the need for more frequent contacts with 
officials grant him/her a more realistic corruption perception than that of his/her fellows whose contacts with red tape are scarce.

Another important factor that influences corruption perception is education. I intentionally leave it out from this equation since the effect of education is already absorbed by age and occupation.

Further on, one's corruption perception is influenced by the size of one's town of residence. There are many factors, which facilitate the spread of corruption, which is likely to be reflected in corruption perceptions, in large cities. Some of these are listed below:

- In large cities there are more bureaucratic positions since the cities serve as administrative centers for the regions. There is also more police and more hospitals.

- Bureaucrats of large towns usually decide about larger sums of money.

- In large cities there are more opportunities to spend money, and there are more advertisements. Thus, the pressure for impulse buying is stronger, and more money is necessary.

- People living is large cities are less likely to have private gardens. In the extreme case when the officials are not paid salary for longer time, which has happened in Ukraine, they are much more dependent on bribes in the large cities.

- In Ukraine officials of the big cities are much more likely to meet rich customers since big cities are usually the centres of business activity.

- Large cities are also the centres of political life.

- In the large cities information is spread more easily. People read more newspapers, since there are more newspapers available. There are usually more TV and radio channels, better access to the internet. 
On the other hand, as it was already discussed in the previous section, in large towns people do not know each other that well. Thus it is almost impossible in the large cities to exercise effectively the mechanisms of social punishment. The impact of lack of information about fellow neighbors on corruption and corruption perceptions depends on the set of values of town communities. If corruption is perceived negatively, the ability of the small towns to socially punish wrongdoers might lead to less corruption, which is then reflected in lower corruption perceived. If, on the other hand corruption is seen as a norm, those who are not corrupt may be seen as social outliers, and the mechanisms of social punishment may lead to more corruption.

In the light of the above arguments, one arrives at the following relationship

$$
C_{i}=f_{2}\left(F_{i}, S, T, O, A, G\right)+e_{2}
$$

Where

Dependent variable: corruption perception in institution $i\left(C_{i}\right)$

\section{Independent variables:}

Frequency of contacts to institution $i\left(F_{i}\right)$

Source of information about corruption $(S)$

The size of the respondent's town of residence $(T)$

Occupational dummies $(O)$

Respondent's age $(A)$ and gender $(G)$

\section{Data problems and data transformations}


As it is explained in the data section corruption perception and number of contacts to the institutions are institution specific, whereas willingness to give a bribe is not. The question arises whether to construct one general corruption perception out of the seventeen institution specific corruption perceptions or run the model above for each institution separately, or to combine these two approaches and pool together some of the institutions' corruption perceptions. None of the proposed approaches is perfect. If one constructs a single corruption perception variable one most certainly runs the risk of imperfectly choosing the procedure of aggregation (the institutions are very different and it is difficult to choose weights each institution should have in the aggregate outcome) and looses information. In addition, one cannot address the different types of the benefits from corruption in different institutions. On the other hand, if one runs seventeen different analyses, one is in the danger to misinterpret the coefficients, since willingness to give bribe, which might be determined by experiences in one institution, might be attributed to another. The best seems to be the middle path: pool together the institutions that belong to one category and leave separate the others.

There is one more reason for pooling some of the institutions together: that is missing values and sampling zeroes in the institutions specific variables. There are only two variables that capture institution specificities: corruption perception and number of contacts to the institution. These variables are the most important to distinguish one institution from the other. Unfortunately, there are very few respondents who actually visited some of institutions. There are even fewer respondents who both visited the institutions and reveal their corruption perception (see table 2). The contingency tables look still worse: in many cases there is no observations in the cells of frequent visitors with lower corruption perceptions, or the few respondents who visited the institutions the most often distributed their corruption perception in very chaotic manner. The lack of observations and lots of zeroes in contingency tables make the potential results very unreliable. The solution is to pool together some institutions. For example ministries, presidential administration and parliament I pooled to the central 
government group. There are eleven resulting institutions. For the description which original institutions are included to which resulting institution see the table 4 .

For all the resulting institutions it is necessary co calculate resulting corruption perception and frequency of visits. Three cases are to be distinguished depending on whether the respondent provided his corruption perception (frequency of visits) for al the included institutions, some of them, or none.

I. If the respondent provided his/her corruption perception (or frequency of visits) in all the organizations included, the rounded average was computed and used as his/her corruption perception (or frequency of visits) for the resulting institution

II. If the respondent did not provide his perception of corruption (frequency of visits) in some of the institutions, average of the rest was computed and I assigned this number to his/her perception of corruption (frequency of visits) in the resulting institution.

III. If the respondent did not provide his perception of corruption (frequency of visits) in any of the institutions, N/A was assigned to the resulting institution.

Unfortunately, even after the data transformation, contingency tables contained a lot of zeros (for the number of responses in each of the contingency table column and the average perceptions of corruption see table 5). The only other possibility to reduce the number of zeroes was to diminish the number of the categories of frequency of visits variable. The cut point I used was the requirement that contingency tables have in each cell not less than five observations as it is the usual rule in the contingency table analysis (Agresti 1996). For the resulting categories, means of corruption perception, and numbers of observations see Table 5.

Even after the data transformations suggested above were performed, the response rates for corruption perception and number of visits to the relevant institutions in some cases 
were very low (around $50 \%$ of the sample for the state TV, see table 2.), and, thus, the question arose whether those people who answered all the questions constitute a representative sample. In order to avoid possible self-selection bias I use Heckman's correction approach (Heckman, 1979): first I run correction equations, save Heckman's lambda (inverse Mill's ratio) and include it in the right hand side of the main equations. For the specification of correction equations and the discussion on the outcome of their estimation see appendix 1.

\section{The method of estimation}

The resulting equations are the following

Main equations

$$
\begin{aligned}
& B=\operatorname{Pr}\left(\beta_{b 1} \text { Const }+\beta_{b 2} C_{i}+\beta_{b 3} I+\beta_{b 4} T+\beta_{b 5} O+\beta_{b 6} A+\beta_{b 7} X+\beta_{b 8} \lambda_{b}\right)+e_{1} \\
& C_{i}=\operatorname{Pr}\left(\beta_{c 1} \text { Const }+\beta_{c 2} F_{i}+\beta_{c 3} S+\beta_{c 4} T+\beta_{c 5} O+\beta_{c 6} A+\beta_{c 7} X+\beta_{c 8} \lambda_{c}\right)+e_{2}
\end{aligned}
$$

Correction equations:

$$
\begin{aligned}
& D_{W G B}=\operatorname{Pr}\left(\alpha_{10} \text { Const }+\alpha_{11} A+\alpha_{12} A^{2}+\alpha_{13} E+\alpha_{14} X\right)+e_{3} \\
& D_{C P}=\operatorname{Pr}\left(\alpha_{20} \text { Const }+\alpha_{21} A+\alpha_{22} A^{2}+\alpha_{23} E+\alpha_{24} X\right)+e_{4}
\end{aligned}
$$

Where

$\operatorname{Pr}-$ normal probability distribution

$B$ - perceived necessity to pay bribe

$C_{i}$ - corruption perception in institution $i$

$F_{i}$ - frequency of contacts to institution $i$ 
$S$ - source of information about corruption

$T$ - the size of the town where the respondent lives

$O$ - occupational dummies

$I$ - perceived inactiveness of the government in fighting corruption

$D_{W G B}$ - dummy equal to 0 if no value is missing in all the variables present in the Willingness to Give Bribe equation, and 1 if at least one value is missing

$D_{C P}$ - dummy equal to 0 if no value is missing in all the variables present in the Willingness to Give Bribe equation, and 1 if at least one value is missing

$A$ - age

$E$ - education

$X$ - gender

$\lambda_{b}$ and $\lambda_{c}$ are inverse Mill's ratios coming from the correction equations

Where

Perceived necessity to give bribe is a categorical ordered variable that varies from one (it is not necessary to give a bribe) to five (bribe is unavoidable). It is not institution specific.

Corruption perception in a certain institution was originally categorical ordered variable that varied from one (very clean institution) into five (very corrupt institution). It is institution specific. In the analysis the variable is split to five dummies. One of them is omitted in order to avoid the dummy trap.

Town size was originally ordered categorical variable that varied from one (village) to five (city with more than 500000 of inhabitants). It is also split to a set of five dummies. The dummy for the smallest village is omitted.

The frequency of contacts with institutions was originally a categorical ordered variable that varied from one (never visited) to four (visited more than ten times during the 
last twelve months). It is institution specific. I split it into four dummies. The "never visited" dummy is omitted.

Sources of information about corruption include press, radio, television, friends, relatives, and strangers. They are not institution specific. There are six dummies with one if the respondent used this source and zero otherwise. In order to correct for the possible disbelief to the mass media I multiplied the dummies for the mass media by categorical variable representing "perceived trust to the media". The latter ranges from one (the respondent totally trusts the mass media) to five (the respondent completely distrusts the mass media). The resulting categorical variables for the means of mass media vary from zero (the respondent does not learn about corruption from the mass media at all) through one (the respondent learns about corruption, among other sources, from the mass media and completely trusts the mass media) to five (the respondent learns about corruption, among other sources, from the mass media but thinks that the information there is completely untruthful). Each of the resulting categorical variables is then split into six dummies. I omit the zero dummy (a person does not learn about corruption from this particular source of information).

Age is a continuous variable.

Education was originally a categorical variable that varied from one to nine. I split education variable into the set of nine dummies and left one of them out in order to avoid the dummy trap.

Sex is represented by a dummy equal to one if the respondent is male and two if the respondent is female.

The system of main equations is of triangular form $(C$ is included to the first equation but $B$ is not included to the second), and, thus, the second equation might be consistently estimated independently of the first but not vice versa. However, I might gain efficiency if I 
estimate both of the equations simultaneously. There are two types of correlations, which make me to vote for simultaneous estimation. Firstly, similarly to the seemingly unrelated regressions, the error terms of the equations are likely to be influenced by the same factors, and, thus, might be correlated (in fact I did find a strong correlation of errors when I did the estimates). The possible factors that may influence both of the errors are the specificity of Ukrainian population, individual characteristics of the respondents, their definition of corruption and attitude to it, possible fear to respond negatively to the questions about corruption, etc. The second correlation is caused by the presence of the Corruption Perception variable in the first equation.

Thus, technically, the estimation of the system above means estimation of twoequation joint ordered probits (I use probits because it is much easier to model simultaneous equations for this case than for logits). For the technical details of programming and estimation see appendix 1 .

\section{Results}

For the outcomes of the equation-by-equation analysis see tables 6 . and 7. Note that the willingness to give bribe equation is not estimated consistently (the consistent estimates are obtained by simultaneous approach), therefore the results are different from those in tables 8 and 9 (simultaneous estimates). The outcomes of correction equations are presented in appendix 1in the tables A1-1 and A1-2. For brief description of all the variables see table 3.

Surprisingly, the coefficient of the "town size four" dummy (town more than 200000 of inhabitants and less than 500000 of inhabitants) behaved differently than the rest of the town size dummies: it is in most cases positive and significant, while the other coefficients are negative. It seems to be quite difficult to explain this phenomenon (I will discuss the possible explanations in the relevant section of the results interpretation). The results might be just 
spurious due to possible collinearity. In order to investigate this issue I regressed the town size four dummy onto all other the variables present in the equations. The $\mathrm{R}^{2}$, which came out of these regressions, was around 0.3 . It is somewhat small to blame multicollinearity, however too large to claim independence. So, I excluded the dummy from the equations and run simultaneous system once more. The results appeared somewhat different in some particular institutions, but the overall pattern was consistent with the original estimates. The results of the estimation without town size four dummy are available upon the request.

The rest of this section is organized as follows. I start with presenting the main results, proceed with supplementary results and finish with the outcomes of correction equations.

\subsection{Main results}

Main results include answers to four questions. The first is whether willingness of the population to give bribes is associated with corruption perception. The second is whether the government is an important player in anti corruption game, i.e. whether its perceived willingness to fight corruption is associated with the willingness of the population to give bribes. The third is whether corruption perception of the general public is close to reality, i.e. whether one's perception of corruption depends on the frequency of visits to the relevant institution. The fourth is whether mass media has the power to influence corruption perceptions of the population.

\subsubsection{Is willingness to give bribes associated with corruption perception?}

In both of the outcomes with and without town size four dummy corruption perception is positively and significantly associated with the willingness to give bribe. Moreover, in both 
the outcomes (with and without town size four dummy) and in all the eleven cases the relevant coefficients increase in value and significance with corruption perception: the more corrupt the person perceives the institutions to be the more willing he/she is to give bribes.

\subsubsection{Is perceived willingness of the government to fight corruption associated with the} willingness to give bribes?

As one can see from the outcome table there is almost no relationship. Obviously, the government is not an important player in the anti-corruption struggle in Ukraine. $63 \%$ of the respondents state that they agree or rather agree that the government does not do anything to fight corruption. Only $8 \%$ of the respondents disagreed or rather disagreed with the statement above.

\subsubsection{Is frequency of visits to a particular institution significantly associated with corruption perception?}

In five cases out of eleven the relevant coefficients are significant at conventional levels. In the cases of local government, juridical institutions and police the more one goes to these institutions the more corrupt he/she perceives them to be. The same is true for the most frequent visitors of medical establishments (more than ten times per year), while people who visit them less often perceive them to be less corrupt. Inspections are also close to the point when frequent visitors perceive them to be more corrupt: the relevant coefficient is at the edge of significance in the analysis with town size four and is not significant without town size four. Privatization authorities are perceived less corrupt if one goes there one or two times, but more corrupt if he/she goes there more than two times per year. 


\subsubsection{Are mass media influential in creating corruption perception?}

To some extent yes. People who get information about corruption from press or television tend to perceive state institutions to be less corrupt than the rest of the population believes. On the other hand people who listen to the radio perceive some of the state institutions to be more corrupt.

\subsection{Supplementary results}

This section describes the results, which do not fall to the core part of this paper, but are also interesting. The first sub-section discusses how the information about corruption obtained from friends, strangers and personal experience influences the perception of corruption. The second subsection describes the effect of the respondent's town of residence. The third one proceeds with the effect of occupation, age and gender. The forth subsection comments on correction equations.

\subsubsection{Friends, strangers and personal experience}

People who learn about corruption from friends tend to perceive most of the state institutions to be less corrupt. The effect of strangers is not that uniform. People who learn about corruption from strangers perceive juridical institutions and educational establishments to be more corrupt, while they think that privatization authorities are less corrupt comparing to the opinion of the rest of population.

Again, as it was expected, people who have the information about corruption from personal experience perceive the institutions to be more corrupt. 


\subsubsection{Town size}

The respondents from towns sized two, three and five (small towns, bigger towns up to 200000 of inhabitants and cities more than 500000 of inhabitants) perceive state institutions to be more corrupt, but they are less willing to give bribes. On the other hand the respondents living in towns sized four (towns from 200000 to 500000 of inhabitants) tend to perceive state institutions to be less corrupt, but they are more willing to give bribes.

Several arguments that support the idea that the bigger the town is the more corrupt the state institutions are perceived were discussed in methodology section. The outcome from the econometric analysis generally supports this suggestion: many town size dummies are positive and significant. However, there is no trend similar to corruption perception willingness to give bribe relation, where the relevant coefficients increased with the corruption dummies. Another surprising thing is that while many town size two, three and five coefficients are positive in corruption perception equation, town size four coefficient is negative and often significant. This outcome seems spurious. The only difference between the towns sized four and the rest, besides the size, is that the towns sized four are usually small administrative centres, while town sized five are very big administrative centres, and all the other towns are not administrative centres at all. There are around fifteen of towns sized four, which are situated all over Ukraine. So, it is very improbable that the difference in the results was caused by some kind of regional pattern. It might be that towns sized four have a unique culture, as for example peasants do. However, it is difficult to say now what is the difference in the cultures and why it causes such a difference in the results. This seems to be the question for sociologists.

In the case of willingness to give bribe equation the story is opposite to that of corruption perception equation: people in towns sized two, three and five are less willing to 
give bribes given their corruption perception. In the towns sized four, residents are more willing to give bribes, given their corruption perception.

The lower willingness to give bribes in the large towns may be explained by the fact that the future benefits of the bribe in large towns are smaller. In big towns there are much more state officials and the probability that one meets the same official the next time he/she visits the institution is smaller than in small towns. Thus, when a person gives a bribe in the small town, he might expect that when he/she sees the official for the next time, he/she will be treated better since the official would expect to get bribe again. On the other hand, in bigger towns, where people do not meet each other that often, the person can not expect better treatment in the future for the bribe in present.

The remaining puzzle is the towns sized four problem: why they behave differently from the other towns. I do not have a sufficient explanation for this puzzle. It may be caused by small regional centres' culture, or it might be just spurious.

\subsubsection{Occupation, age and gender}

Few occupational dummies are significant. It is worth to mention only some. Businessmen and peasants are more willing to give bribes. This finding is not surprising since businessmen are those who can benefit from corruption much more than people of other occupations. Peasants are more willing to give bribes to the special peasants' culture, as it was described in the methodology section. Unemployed perceive some state institutions to be more corrupt, which may be contribute to their resentment to state in general.

Older people perceive state institutions to be more corrupt, but they are less willing to give bribe as compared to younger part of population. The effect of gender is unclear. Women tend to perceive central and local governments and juridical institutions to be more 
corrupt, while privatization authorities to be less corrupt as compared to men' perception. In the willingness to give bribe there is almost no difference. 


\section{Conclusion}

This paper presents empirical evidence that corruption perceptions are significantly associated with the willingness of the population to give bribes in Ukraine. If one perceives an institution to be very corrupt, he/she is more willing to pay a bribe there. This way corruption perception may actually facilitate corruption.

Corruption perceptions, being partially a product of corruption itself, do not always reflect reality properly. If one assumes that those people who visit the state institutions most often have the most adequate perception of corruption, then from the econometric analysis follows that the Ukrainian population tend to underestimate corruption in the local government, juridical institutions, and police. On the other hand, Ukrainians tend to overestimate corruption in banks. The last effect should, however, be taken with caution because those people who visit these institutions most often use very limited set of services, and, thus, may have clear perception of corruption only in the departments of these institutions they visit.

Special attention should be paid to the mass media as the source of corruption perceptions. In the countries such as Ukraine, where corruption scandals very rarely lead to legal accusations, the mass media might actually support corruption. If the media provides people with corruption perceptions that are darker than the reality, it may make people to believe that they have to give bribes. In the case of five institutions out of eleven (juridical institutions, army, medical establishments, privatization authorities and banks) people who learn about corruption from press perceive the institutions to be less corrupt. The same holds in the case of two institutions for state TV (central government and privatization authorities). While people who learn about corruption from radio perceive central government, medical establishments and privatization authorities to be more corrupt. 
The other sources of information about corruption such as friends and personal experience are much more influential. Friends are significant in seven to nine cases of different institutions out of eleven depending on whether town sized four is included or not. Personal experience is important in all the institutions. People who learn about corruption from friends tend to perceive the institutions to be less corrupt, while people who learn about corruption from personal experience perceive the institutions to be more corrupt. The last finding is somewhat biased since personal experience with corruption provider worse corruption perception from definition.

An interesting and extremely informative and important finding is that perceived willingness of the government to fight corruption is never significantly associated with the willingness of the population to give bribes. This might be a symptom of the population totally ignoring its government lacking hope that it will ever help. This is a sign of the lack of democracy in the country and prerequisite to the authoritarian regime in the future. Actually, only a minor percentage of the respondents believe that the government is really doing something to fight corruption.

The message of the whole paper is that corruption perceptions, as any kinds of perceptions that are spread all over the population should be paid much more attention than it was done before, as suggested in the literature review section. The perceptions might actually facilitate the negative or positive processes that take place in society. 


\section{References}

Abramovitz, M. and Stegun, I. A. 1964. "Handbook of mathematical functions: with formulas, graphs, and mathematical tables" Washington, D.C : National Bureau of Standards, $1046 \mathrm{p}$.

Agresti, A. 1996. An Introduction to Categorical Data Analysis. A Wiley-Interscience Publication. John Wiley \& sons, Inc. New York. 290 p.

Akerlof, G. 1980. “A Theory of Social Custom, of Which Unemployment May be One Consequence" Quarterly Journal of Economics, 94, pp.749-775

Antoch, J. and Hanousek, J. 1999. “A specification Test for Discrete Choice Models" CERGE-EI discussion paper series No. 32/99, 26 p.

Andvig, C. 1991. "The Economics of Corruption: a Survey” Studi Economici, 43 (1), pp. 5794

Diamond, P. and D. Fudenberg. 1987. "Rational-Expectations Business Cycles in Search Equilibrium” Journal of Political Economy, 97(3), June, p. 606-19

Farrell, J, and Saloner G. 1986. "Installed Base and Compatibility: Innovation, Product Preannouncements, and Predation," American Economic Review, LXXVI p. 940-955

Gilboa, I. and Schmeidler, D. 1995. "Case-Based Decision Theory" Quarterly Journal of Economics, 110(3), August, p. 605-39

Harrison, L. E. 1985. Underdevelopment is the State of Mind. Lanham MD: Madison Books

Heckman, J. 1979. "Sample Selection Bias as a Specification Error" Econometrica, 47, pp. 153-161

Hofstede, G. 1991. Cultures and Organizations. McGraw-Hill International Ltd, UK 
Howitt, P. and R. McAfee. 1988. "Stability of Equilibria with Externalities" Quarterly Journal of Economics, CIII p. 261-278

Krugman P. 1991. "History Versus Expectations" The Quarterly Journal of Economics, May, p. $651-667$

Little, R. and Rubin, D. 1987. "Statistical Analysis with Missing Data” John Wiley \& Sons, New York

Lui, F. 1986. "A Dynamic Model of Corruption Deterrence”, Journal of Public Economics, pp. $215-236$

Matsuyama K. 1991. "Increasing Returns, Industrialisation, and Indeterminacy of Equilibrium" The Quarterly Journal of Economics, May, p. 617-650

Mauro, P. 1996. "The Effects of Corruption on Growth, Investment, and Government Expenditure" IMF Working Paper, WP/96/98

Questions of National Integrity. 1998. Pravo. Kyiv.

Mofatt, P. and Peters, S. 2000. "Grouped zero-inflated count data models of coital frequency" Journal of Population Economics, vol. 13, p. 205-220

Puhani, P. 2000. “The Heckman Correction for Sample Selection and Its Critique” Journal of Economic Surveys vol. 14 (1), February, p. 53-68

Rose-Ackerman S. 1997. "Corruption and Development" Annual Bank Conference on Development Economics, April 30 and May 1, 1997, Washington D.C.

Sah, R. 1987. "Persistence and Pervasiveness of Corruption" The World Bank Conference on Political Economy: Theory and Policy Implications, 17-19 June, 1987

Saha, A. Capps, O. and P. Byrne. 1997. "Calculating marginal effects in models for zero expenditures in household budgets using a Heckman-type correction" Applied 
Economics, vol. 29, p. 1311-1316

Schelling, T. 1973. "Hockey Helmets, Concealed Weapons, and Daylight Saving: a Study of Binary Choices with Externalities", Journal of Conflict Resolution, pp. 381-428

Tanzi, V. 1998. "Corruption Around the World: Causes, Consequences, Scope, and Cures" IMF Working Paper, WP/98/63 
Table 1.

Sources of information about corruption the respondents use

\begin{tabular}{|l|c|}
\hline \multicolumn{1}{|c|}{ Source of information } & $\begin{array}{c}\text { \% of the respondents who } \\
\text { used the source }\end{array}$ \\
\hline Press & 49,43 \\
\hline Television & 66,16 \\
\hline Radio & 27,52 \\
\hline Acquaintances and Friends & 41,68 \\
\hline Strangers on Streets and in the Means of Transportation & 15,73 \\
\hline Personal Experience & 25,19 \\
\hline Difficult to Say/Do Not Know & 3,71 \\
\hline
\end{tabular}

Table 2.

List of institutions with the response rates for both corruption perception and the frequency of visits

\begin{tabular}{|l|l|c|}
\hline No & \multicolumn{1}{|c|}{ Organizations } & $\begin{array}{c}\text { Response rates for both } \\
\text { corruption perceptions } \\
\text { and frequency of visits, \% }\end{array}$ \\
\hline 1 & $\begin{array}{l}\text { Ministries and Other Central Executive } \\
\text { Bodies }\end{array}$ & 73 \\
\hline 2 & Presidential Administration & 65 \\
\hline 3 & Parliament (Verkhovna Rada) & 73 \\
\hline 4 & Local Government & 78 \\
\hline 5 & Public Prosecutor & 70 \\
\hline 6 & Juridical System & 72 \\
\hline 7 & Customs & 69 \\
\hline 8 & Tax Inspection & 71 \\
\hline 9 & State Auto Inspection & 77 \\
\hline 10 & Local militia (police) & 78 \\
\hline 11 & Army & 65 \\
\hline 12 & Privatization Authorities & 63 \\
\hline 13 & Banks & 58 \\
\hline 14 & Secondary Education Institutions & 76 \\
\hline 15 & Higher Education Institutions & 78 \\
\hline 16 & State Medical Establishments & 84 \\
\hline 17 & State Television & 49 \\
\hline
\end{tabular}


Table 3

A brief description of the variables present in the correction and main equations

\begin{tabular}{|c|c|c|}
\hline Variable & \begin{tabular}{|c|} 
Description \\
\end{tabular} & Comments \\
\hline Corruption Perception 1 & The institution is not corrupt at all & Omitted in order to avoid dummy trap \\
\hline Corruption Perception 2 & The institution is rather not corrupt & \\
\hline Corruption Perception 3 & $\begin{array}{l}\text { One can face corruptness of officials } \\
\text { in approximately as many cases as } \\
\text { non-corruptness there }\end{array}$ & \\
\hline Corruption Perception 4 & The institution is rather corrupt & \\
\hline Corruption Perception 5 & The institution is heavily corrupt & \\
\hline No fight 1 & $\begin{array}{l}\text { The respondent completely agrees that } \\
\text { the government does not do anything } \\
\text { to fight corruption }\end{array}$ & Omitted \\
\hline No fight 2 & $\begin{array}{l}\text { The respondent rather agrees that the } \\
\text { government does not do anything to } \\
\text { fight corruption }\end{array}$ & \\
\hline No fight 3 & $\begin{array}{l}\text { The government fight corruption in as } \\
\text { may cases as does not fight it }\end{array}$ & \\
\hline No fight 4 & $\begin{array}{l}\text { The respondent rather disagrees that } \\
\text { the government does not do anything } \\
\text { to fight corruption }\end{array}$ & \\
\hline No fight 5 & $\begin{array}{l}\text { The respondent completely disagrees } \\
\text { that the government does not do } \\
\text { anything to fight corruption }\end{array}$ & \\
\hline Town size 1 & Village & Omitted \\
\hline Town size 2 & $\begin{array}{l}\text { Something in between village and the } \\
\text { small town }\end{array}$ & \\
\hline Town size 3 & Town up to 200000 of inhabitants & \\
\hline Town size 4 & $\begin{array}{l}\text { Town more than } 200000 \text { but less than } \\
500000 \text { of inhabitants }\end{array}$ & \\
\hline Town size 5 & City more than 500000 of inhabitants & \\
\hline Peasant & Agriculture laborer & \\
\hline Worker & worker outside of the agriculture & \\
\hline Clerk & Clerical without higher education & \\
\hline Specialist & Specialist (higher education required) & \\
\hline Businessman & Businessman or self employed & \\
\hline Retired & Retired & \\
\hline Student & Student or pupil & \\
\hline Homemaker & Homemaker & \\
\hline Unemployed & Unemployed looking for a job & \\
\hline Other & Other occupation & Omitted \\
\hline Correction variable & $\begin{array}{l}\text { Inverse Mill's ration from the } \\
\text { corresponding correction equation }\end{array}$ & \\
\hline Frequency of Visits $=0$ & $\begin{array}{l}\text { The respondent never visited the } \\
\text { institution in question during the } 12 \\
\text { month before the survey }\end{array}$ & Omitted \\
\hline Frequency of Visits $=1$ & Visited one or two times & \\
\hline Frequency of Visits $=2$ & $\begin{array}{l}\text { Visited more than two but less then } \\
\text { ten times }\end{array}$ & \\
\hline Frequency of Visits $=3$ & Visited more than ten times & \\
\hline Press $=0$ & $\begin{array}{l}\text { The respondent does not learn about } \\
\text { corruption from the press }\end{array}$ & Omitted \\
\hline
\end{tabular}




\begin{tabular}{|c|c|c|}
\hline Press $=1$ & $\begin{array}{l}\text { Learns about corruption from the } \\
\text { press and trusts the mass media } \\
\text { entirely }\end{array}$ & \\
\hline Press $=2$ & $\begin{array}{l}\text { Learns about corruption from the } \\
\text { press and thinks that the information } \\
\text { about corruption in the mass media is } \\
\text { in most cases truthful }\end{array}$ & \\
\hline Press $=3$ & $\begin{array}{l}\text { Learns about corruption from the } \\
\text { press and thinks that it is difficult to } \\
\text { say whether the information about } \\
\text { corruption published in the mass } \\
\text { media is truthful }\end{array}$ & \\
\hline Press $=4$ & $\begin{array}{l}\text { Learns about corruption from the } \\
\text { press and believes that the information } \\
\text { about corruption in the mass media is } \\
\text { often untruthful }\end{array}$ & \\
\hline Press $=5$ & $\begin{array}{l}\text { Learns about corruption from the } \\
\text { press and believes that the information } \\
\text { about corruption in the mass media is } \\
\text { always untruthful }\end{array}$ & \\
\hline $\mathrm{TV}=0$ & $\begin{array}{l}\text { The respondent does not learn about } \\
\text { corruption from television }\end{array}$ & Omitted \\
\hline $\mathrm{TV}=1$ & $\begin{array}{l}\text { Learns about corruption from } \\
\text { television and trusts the mass media } \\
\text { entirely }\end{array}$ & \\
\hline $\mathrm{TV}=2$ & $\begin{array}{l}\text { Learns about corruption from } \\
\text { television and thinks that the } \\
\text { information about corruption in the } \\
\text { mass media is in most cases truthful }\end{array}$ & \\
\hline $\mathrm{TV}=3$ & $\begin{array}{l}\text { Learns about corruption from } \\
\text { television and thinks that it is difficult } \\
\text { to say whether the information about } \\
\text { corruption published in the mass } \\
\text { media is truthful }\end{array}$ & \\
\hline $\mathrm{TV}=4$ & $\begin{array}{l}\text { Learns about corruption from } \\
\text { television and believes that the } \\
\text { information about corruption in the } \\
\text { mass media is often untruthful }\end{array}$ & \\
\hline $\mathrm{TV}=5$ & $\begin{array}{l}\text { Learns about corruption from } \\
\text { television and believes that the } \\
\text { information about corruption in the } \\
\text { mass media is always untruthful }\end{array}$ & \\
\hline Radio $=0$ & $\begin{array}{l}\text { The respondent does not learn about } \\
\text { corruption from radio }\end{array}$ & Omitted \\
\hline Radio $=1$ & $\begin{array}{l}\text { Learns about corruption from radio } \\
\text { and trusts the mass media entirely }\end{array}$ & \\
\hline Radio $=2$ & $\begin{array}{l}\text { Learns about corruption from radio } \\
\text { and thinks that the information about } \\
\text { corruption in the mass media is in } \\
\text { most cases truthful }\end{array}$ & \\
\hline Radio $=3$ & $\begin{array}{l}\text { Learns about corruption from radio } \\
\text { and thinks that it is difficult to say } \\
\text { whether the information about } \\
\text { corruption published in the mass } \\
\text { media is truthful }\end{array}$ & \\
\hline Radio $=4$ & $\begin{array}{l}\text { Learns about corruption from radio } \\
\text { and believes that the information } \\
\text { about corruption in the mass media is } \\
\text { often untruthful }\end{array}$ & \\
\hline Radio $=5$ & $\begin{array}{l}\text { Learns about corruption from radio } \\
\text { and believes that the information }\end{array}$ & \\
\hline
\end{tabular}




\begin{tabular}{|c|c|c|}
\hline & $\begin{array}{l}\text { about corruption in the mass media is } \\
\text { always untruthful }\end{array}$ & \\
\hline Friends & $\begin{array}{l}\text { Learns about corruption from friends } \\
\text { and relatives }\end{array}$ & \\
\hline Strangers & $\begin{array}{|lll|}\begin{array}{l}\text { Learns about corruption from } \\
\text { strangers }\end{array} & & \\
\end{array}$ & \\
\hline Experience & $\begin{array}{l}\text { Learns about corruption from personal } \\
\text { experience }\end{array}$ & \\
\hline Age & Age of the respondent & \\
\hline Age square & Squared age of the respondent & \\
\hline Education 1 & Less than 4 years of school & Omitted \\
\hline Education 2 & More than 4 years and less than 7 & \\
\hline Education 3 & More than 7 years and less than 10 & \\
\hline Education 4 & Specialized school after 7-8 years & \\
\hline Education 5 & \begin{tabular}{|l}
$\begin{array}{l}\text { Full secondary education }(10-11 \\
\text { years })\end{array}$ \\
\end{tabular} & \\
\hline Education 6 & Specialized after $10-11$ years & \\
\hline Education 7 & Full secondary specialized education & \\
\hline Education 8 & $\begin{array}{l}\text { More than } 3 \text { years of higher education, } \\
\text { but not full higher ed. }\end{array}$ & \\
\hline Education 9 & Full higher education & \\
\hline Gender & 1 - male, 2 - female & \\
\hline
\end{tabular}

Table 4.

Resulting institutions and the response rates

\begin{tabular}{|l|l|l|c|}
\hline No & Name & Institutions included & Response rate, \% \\
\hline 1 & Central Government & $\begin{array}{l}\text { Ministries, Presidential Administration, } \\
\text { Parliament }\end{array}$ & 73 \\
\hline 2 & Local Government & Local Government & 78 \\
\hline 3 & Juridical System & Courts and Prosecutors & 75 \\
\hline 4 & Inspections & Customs and Tax Police & 76 \\
\hline 5 & Police & Auto Inspection and Police (militia) & 82 \\
\hline 6 & Army & Army & 65 \\
\hline 7 & Educational Establishments & Schools and Universities & 82 \\
\hline 8 & Medical Establishments & Medical Establishments & 84 \\
\hline 9 & State Television & State Television & 49 \\
\hline 10 & Privatization Authorities & Privatization Authorities & 63 \\
\hline 11 & Banks & Banks & 58 \\
\hline
\end{tabular}


Table 5.

Mean perception of the level of corruption in the institutions depending on the number of contacts to the institutions during the last 12 months before the survey

Corrected categories

\begin{tabular}{|c|c|c|c|c|c|}
\hline Institution & $\begin{array}{c}\text { Mean } \\
\text { and No } \\
\text { of } \\
\text { observ }^{8} \text {. }\end{array}$ & $\begin{array}{l}\text { Never visited } \\
\text { during the last } \\
12 \text { months }\end{array}$ & $\begin{array}{l}\text { Visited once or } \\
\text { twice }\end{array}$ & $\begin{array}{l}\text { Visited more than } \\
2 \text { but less then } 10 \\
\text { times }\end{array}$ & $\begin{array}{l}\text { Visited more than } \\
10 \text { times }\end{array}$ \\
\hline $\begin{array}{l}\text { Central } \\
\text { Government }\end{array}$ & $\begin{array}{l}\text { Mean } \\
\mathrm{N}\end{array}$ & $\begin{array}{l}4.15 \\
1502\end{array}$ & $\begin{array}{c}4.32 \\
28\end{array}$ & $\begin{array}{l}\text { N/A } \\
\text { N/A }\end{array}$ & $\begin{array}{l}\text { N/A } \\
\text { N/A }\end{array}$ \\
\hline $\begin{array}{l}\text { Local } \\
\text { Government }\end{array}$ & $\begin{array}{l}\text { Mean } \\
\mathrm{N}\end{array}$ & $\begin{array}{l}4.12 \\
1220\end{array}$ & $\begin{array}{l}4.06 \\
310 \\
\end{array}$ & $\begin{array}{l}4.18 \\
130 \\
\end{array}$ & $\begin{array}{l}\text { N/A } \\
\text { N/A }\end{array}$ \\
\hline $\begin{array}{l}\text { Juridical } \\
\text { Institutions }\end{array}$ & $\begin{array}{l}\text { Mean } \\
\mathrm{N}\end{array}$ & $\begin{array}{l}4.09 \\
1440\end{array}$ & $\begin{array}{l}4.25 \\
141 \\
\end{array}$ & $\begin{array}{l}\text { N/A } \\
\text { N/A }\end{array}$ & $\begin{array}{l}\text { N/A } \\
\text { N/A }\end{array}$ \\
\hline Inspections & $\begin{array}{l}\text { Mean } \\
\mathrm{N}\end{array}$ & $\begin{array}{l}4.28 \\
1267\end{array}$ & $\begin{array}{l}4.36 \\
335\end{array}$ & $\begin{array}{l}\text { N/A } \\
\text { N/A }\end{array}$ & $\begin{array}{l}\text { N/A } \\
\text { N/A }\end{array}$ \\
\hline Police & $\begin{array}{l}\text { Mean } \\
\mathrm{N}\end{array}$ & $\begin{array}{l}4.39 \\
1300\end{array}$ & $\begin{array}{l}4.57 \\
420 \\
\end{array}$ & $\begin{array}{l}\text { N/A } \\
\text { N/A }\end{array}$ & $\begin{array}{l}\text { N/A } \\
\text { N/A }\end{array}$ \\
\hline Army & $\begin{array}{l}\text { Mean } \\
\mathrm{N}\end{array}$ & $\begin{array}{l}3.54 \\
1311\end{array}$ & $\begin{array}{c}3.67 \\
57\end{array}$ & $\begin{array}{l}\text { N/A } \\
\text { N/A }\end{array}$ & $\begin{array}{l}\text { N/A } \\
\text { N/A }\end{array}$ \\
\hline $\begin{array}{l}\text { Educational } \\
\text { Establishments }\end{array}$ & $\begin{array}{l}\text { Mean } \\
\mathrm{N}\end{array}$ & $\begin{array}{l}3.90 \\
1275\end{array}$ & $\begin{array}{l}3.84 \\
276\end{array}$ & $\begin{array}{l}3.91 \\
182\end{array}$ & $\begin{array}{l}\text { N/A } \\
\text { N/A }\end{array}$ \\
\hline $\begin{array}{l}\text { Medical } \\
\text { Establishments }\end{array}$ & $\begin{array}{l}\text { Mean } \\
\mathrm{N}\end{array}$ & $\begin{array}{c}4.25 \\
737\end{array}$ & $\begin{array}{l}4.15 \\
450 \\
\end{array}$ & $\begin{array}{l}4.17 \\
364 \\
\end{array}$ & $\begin{array}{l}4.41 \\
222\end{array}$ \\
\hline State TV & $\begin{array}{l}\text { Mean } \\
\mathrm{N}\end{array}$ & $\begin{array}{l}3.31 \\
1032 \\
\end{array}$ & $\begin{array}{c}3.60 \\
15 \\
\end{array}$ & $\begin{array}{l}\text { N/A } \\
\text { N/A }\end{array}$ & $\begin{array}{l}\text { N/A } \\
\text { N/A }\end{array}$ \\
\hline $\begin{array}{l}\text { Privatization } \\
\text { authorities }\end{array}$ & $\begin{array}{l}\text { Mean } \\
\mathrm{N}\end{array}$ & $\begin{array}{l}3.85 \\
1114\end{array}$ & $\begin{array}{l}3.47 \\
196\end{array}$ & $\begin{array}{c}3.82 \\
22\end{array}$ & $\begin{array}{l}\text { N/A } \\
\text { N/A }\end{array}$ \\
\hline Banks & $\begin{array}{l}\text { Mean } \\
\mathrm{N}\end{array}$ & $\begin{array}{l}3.65 \\
1090 \\
\end{array}$ & $\begin{array}{c}3.22 \\
72 \\
\end{array}$ & $\begin{array}{c}3.29 \\
35 \\
\end{array}$ & $\begin{array}{c}3.12 \\
26 \\
\end{array}$ \\
\hline
\end{tabular}

\footnotetext{
${ }^{8}$ Mean in the mean corruption perception and $\mathrm{N}$ is the number of observations in each cell.
} 
Table 6. Willingness to give bribe equation (equation 4a). Equation-by-equation estimates

\begin{tabular}{|c|c|c|c|c|c|c|c|c|c|c|c|}
\hline $\begin{array}{l}\text { Instituti } \\
\text { Parameter }\end{array}$ & $\begin{array}{c}\text { Central } \\
\text { Govt. }\end{array}$ & $\begin{array}{l}\text { Local } \\
\text { Govt. }\end{array}$ & $\begin{array}{c}\text { Juridic. } \\
\text { Instit. }\end{array}$ & $\begin{array}{c}\text { Inspec- } \\
\text { tions }\end{array}$ & Police & Army & $\begin{array}{l}\text { Educat. } \\
\text { Establ. }\end{array}$ & $\begin{array}{l}\text { Medic. } \\
\text { Establ. }\end{array}$ & $\begin{array}{c}\text { State } \\
\text { TV }\end{array}$ & $\begin{array}{l}\text { Privat. } \\
\text { Author. }\end{array}$ & Banks \\
\hline Constant & $\begin{array}{c}0.35 \\
{[.334]}\end{array}$ & $\begin{array}{c}0.13 \\
{[.646]}\end{array}$ & $\begin{array}{c}0.19 \\
{[.523]}\end{array}$ & $\begin{array}{c}0.04 \\
{[.914]}\end{array}$ & $\begin{array}{c}-0.01 \\
{[.990]} \\
\end{array}$ & $\begin{array}{c}0.26 \\
{[.353]} \\
\end{array}$ & $\begin{array}{c}0.17 \\
{[.532]}\end{array}$ & $\begin{array}{c}0.20 \\
{[.484]}\end{array}$ & $\begin{array}{c}-0.26 \\
{[.487]} \\
\end{array}$ & $\begin{array}{c}0.38 \\
{[.203]}\end{array}$ & $\begin{array}{c}0.10 \\
{[.744]}\end{array}$ \\
\hline $\begin{array}{l}\text { Corruption } \\
\text { Perception } 2 \\
\end{array}$ & $\begin{array}{l}-0.17 \\
{[.554]}\end{array}$ & $\begin{array}{c}0.22 \\
{[.273]}\end{array}$ & $\begin{array}{c}0.19 \\
{[.340]}\end{array}$ & $\begin{array}{c}0.30 \\
{[.294]}\end{array}$ & $\begin{array}{c}0.21 \\
{[.546]}\end{array}$ & $\begin{array}{c}\mathbf{0 . 3 3}^{\mathrm{a}} \\
{[.006]}\end{array}$ & $\begin{array}{c}0.31^{\mathrm{c}} \\
{[.094]}\end{array}$ & $\begin{array}{c}0.21 \\
{[.303]}\end{array}$ & $\begin{array}{c}-0.06 \\
{[.641]}\end{array}$ & $\begin{array}{c}0.14 \\
{[.369]}\end{array}$ & $\begin{array}{c}0.43^{\mathrm{a}} \\
{[.001]}\end{array}$ \\
\hline \begin{tabular}{|l|} 
Corruption \\
Perception 3 \\
\end{tabular} & $\begin{array}{c}0.13 \\
{[.627]}\end{array}$ & $\begin{array}{c}0.37^{\mathbf{b}} \\
{[.021]}\end{array}$ & $\begin{array}{c}0.22 \\
{[.223]}\end{array}$ & $\begin{array}{c}0.32 \\
{[.204]}\end{array}$ & $\begin{array}{c}0.54^{\mathrm{c}} \\
{[.092]}\end{array}$ & $\begin{array}{c}0.44^{\mathrm{a}} \\
{[.000]}\end{array}$ & $\begin{array}{l}\mathbf{0 . 3 5}^{\mathrm{b}} \\
{[.030]}\end{array}$ & $\begin{array}{c}0.32^{\mathrm{c}} \\
{[.074]}\end{array}$ & $\begin{array}{l}0.19^{\mathrm{c}} \\
{[.097]}\end{array}$ & $\begin{array}{c}0.22 \\
{[.127]}\end{array}$ & $\begin{array}{c}0.33^{\mathrm{a}} \\
{[.006]}\end{array}$ \\
\hline \begin{tabular}{|l|} 
Corruption \\
Perception 4
\end{tabular} & $\begin{array}{c}0.15 \\
{[.558]}\end{array}$ & $\begin{array}{c}\mathbf{0 . 3 8}^{\mathrm{b}} \\
{[.017]}\end{array}$ & $\begin{array}{c}0.20 \\
{[.258]}\end{array}$ & $\begin{array}{c}0.41^{\mathrm{c}} \\
{[.099]}\end{array}$ & $\begin{array}{c}0.50 \\
{[.116]}\end{array}$ & $\begin{array}{c}0.40^{\mathrm{a}} \\
{[.001]}\end{array}$ & $\begin{array}{c}0.42^{\mathrm{a}} \\
{[.009]}\end{array}$ & $\begin{array}{c}0.26 \\
{[.135]}\end{array}$ & $\begin{array}{c}0.30^{b} \\
{[.012]}\end{array}$ & $\begin{array}{c}0.08 \\
{[.595]}\end{array}$ & $\begin{array}{c}0.17 \\
{[.169]}\end{array}$ \\
\hline $\begin{array}{l}\text { Corruption } \\
\text { Perception 5 }\end{array}$ & $\begin{array}{c}0.09 \\
{[.723]}\end{array}$ & $\begin{array}{c}\mathbf{0 . 3 5}^{\mathrm{b}} \\
{[.021]}\end{array}$ & $\begin{array}{l}\mathbf{0 . 3 2}^{\mathrm{c}} \\
{[.071]}\end{array}$ & $\begin{array}{l}0.50^{b} \\
{[.040]}\end{array}$ & $\begin{array}{l}0.57^{\mathrm{c}} \\
{[.068]}\end{array}$ & $\begin{array}{c}0.15 \\
{[.173]}\end{array}$ & $\begin{array}{c}0^{0.39^{b}} \\
{[.014]}\end{array}$ & $\begin{array}{c}0.42^{b} \\
{[.013]}\end{array}$ & $\begin{array}{l}\mathrm{O.19}^{\mathrm{c}} \\
{[.095]}\end{array}$ & $\begin{array}{l}-0.01 \\
{[.968]}\end{array}$ & $\begin{array}{c}0.02 \\
{[.869]}\end{array}$ \\
\hline No fight $2^{9}$ & $\begin{array}{c}0.06 \\
{[.447]}\end{array}$ & $\begin{array}{c}0.06 \\
{[.561]}\end{array}$ & $\begin{array}{c}0.09 \\
{[.276]}\end{array}$ & $\begin{array}{c}0.10 \\
{[.228]}\end{array}$ & $\begin{array}{c}0.07 \\
{[.390]}\end{array}$ & $\begin{array}{c}0.03 \\
{[.761]}\end{array}$ & $\begin{array}{c}0.02 \\
{[.756]}\end{array}$ & $\begin{array}{c}0.05 \\
{[.522]} \\
\end{array}$ & $\begin{array}{c}0.02 \\
{[.860]}\end{array}$ & $\begin{array}{c}0.04 \\
{[.672]}\end{array}$ & $\begin{array}{c}-0.05 \\
{[.568]}\end{array}$ \\
\hline No fight 3 & $\begin{array}{c}0.01 \\
{[.919]}\end{array}$ & $\begin{array}{c}0.01 \\
{[.921]}\end{array}$ & $\begin{array}{c}0.04 \\
{[.581]}\end{array}$ & $\begin{array}{c}0.05 \\
{[.461]}\end{array}$ & $\begin{array}{c}0.03 \\
{[.657]}\end{array}$ & & & & $\begin{array}{c}0.01 \\
{[.897]}\end{array}$ & & $\begin{array}{c}-0.07 \\
{[.375]}\end{array}$ \\
\hline No fight 4 & $\begin{array}{l}-0.04 \\
{[.742]} \\
\end{array}$ & $\begin{array}{l}-0.10 \\
{[.442]}\end{array}$ & & & & & & & $\begin{array}{c}0.03 \\
{[.844]}\end{array}$ & & \\
\hline No fight 5 & $\begin{array}{c}0.01 \\
{[.952]}\end{array}$ & $\begin{array}{c}0.02 \\
{[.913]}\end{array}$ & & & & & & & & & \\
\hline Town size 2 & $\begin{array}{l}-0.06 \\
{[.573]}\end{array}$ & $\begin{array}{l}-0.06 \\
{[.568]}\end{array}$ & & & & & $\begin{array}{l}-0.08 \\
{[.410]}\end{array}$ & & $\begin{array}{c}0.01 \\
{[.937]}\end{array}$ & & \\
\hline Town size 3 & $\begin{array}{l}-0.04 \\
{[.694]}\end{array}$ & $\begin{array}{c}0.00 \\
{[.984]}\end{array}$ & & & & & & & $\begin{array}{c}0.11 \\
{[.347]}\end{array}$ & & $\begin{array}{c}0.12 \\
{[.249]}\end{array}$ \\
\hline Town size 4 & $\begin{array}{c}0.14 \\
{[.110]}\end{array}$ & & & & & & & & & & \\
\hline Town size 5 & & $\begin{array}{l}-0.01 \\
{[.941]}\end{array}$ & & & & & & & $\begin{array}{c}0.05 \\
{[.647]}\end{array}$ & & \\
\hline Peasant & $\begin{array}{l}0.57^{b} \\
{[.030]}\end{array}$ & & & & & & & & $\begin{array}{r}0.65 \\
{[.03} \\
\end{array}$ & & $\begin{array}{c}0.43 \\
{[.147]}\end{array}$ \\
\hline Worker & & & & & & & & & & & \\
\hline Clerk & $\begin{array}{c}0.25 \\
{[.259]}\end{array}$ & $\begin{array}{c}0.25 \\
{[.213]}\end{array}$ & $\begin{array}{c}0.20 \\
{[.351]} \\
\end{array}$ & $\begin{array}{c}0.26 \\
{[.214]}\end{array}$ & $\begin{array}{c}0.19 \\
{[.346]}\end{array}$ & & $\begin{array}{c}0.21 \\
{[.288]}\end{array}$ & & $\begin{array}{c}0.31 \\
{[.212]} \\
\end{array}$ & & $\begin{array}{c}0.31 \\
{[.214]}\end{array}$ \\
\hline Specialist & $\begin{array}{c}0.27 \\
{[.218]}\end{array}$ & $\begin{array}{c}0.26 \\
{[.198]}\end{array}$ & $\begin{array}{c}0.25 \\
{[.263]}\end{array}$ & $\begin{array}{c}0.25 \\
{[.240]}\end{array}$ & $\begin{array}{c}0.16 \\
{[.424]}\end{array}$ & $\begin{array}{c}0.33 \\
{[.155]}\end{array}$ & $\begin{array}{c}0.21 \\
{[.304]}\end{array}$ & $\begin{array}{c}0.20 \\
{[.315]}\end{array}$ & $\begin{array}{c}0.32 \\
{[.201]}\end{array}$ & $\begin{array}{c}0.18 \\
{[.435]}\end{array}$ & $\begin{array}{c}0.28 \\
{[.269]}\end{array}$ \\
\hline Businessman & $\begin{array}{c}\mathbf{0 . 6 1}^{\mathrm{b}} \\
{[.014]}\end{array}$ & $\begin{array}{c}0^{0.62^{\mathrm{a}}} \\
{[.006]}\end{array}$ & $\begin{array}{c}\mathbf{0 . 6 1}^{\mathrm{b}} \\
{[.013]}\end{array}$ & $\begin{array}{c}\mathbf{0 . 5 9}^{\mathrm{b}} \\
{[.014]}\end{array}$ & $\begin{array}{l}\mathbf{0 . 5 3}^{\mathrm{b}} \\
{[.022]}\end{array}$ & $\begin{array}{c}0.62^{b} \\
{[.018]}\end{array}$ & $\begin{array}{l}\mathbf{0 . 5 3}^{\mathrm{b}} \\
{[.021]}\end{array}$ & $\begin{array}{l}\mathbf{0 . 5 5}^{\mathrm{b}} \\
{[.018]}\end{array}$ & $\begin{array}{c}0.64^{b} \\
{[.024]}\end{array}$ & $\begin{array}{c}\mathbf{0 . 6 2}^{\mathrm{b}} \\
{[.019]}\end{array}$ & $\begin{array}{l}0.68^{b} \\
{[.017]}\end{array}$ \\
\hline Retired & $\begin{array}{c}\mathbf{0 . 4 1}^{\mathrm{c}} \\
{[.070]}\end{array}$ & $\begin{array}{c}\mathbf{0 . 3 8}^{\mathrm{c}} \\
{[.074]}\end{array}$ & $\begin{array}{c}0.30 \\
{[.188]}\end{array}$ & $\begin{array}{c}\mathbf{0 . 3 8}^{\mathrm{c}} \\
{[.084]}\end{array}$ & $\begin{array}{c}0.25 \\
{[.248]}\end{array}$ & $\begin{array}{c}\mathbf{0 . 4 9}^{\mathrm{b}} \\
{[.043]}\end{array}$ & $\begin{array}{c}\mathbf{0 . 3 7}^{\mathrm{c}} \\
{[.078]}\end{array}$ & $\begin{array}{c}0.32 \\
{[.127]}\end{array}$ & $\begin{array}{c}0.35 \\
{[.176]}\end{array}$ & $\begin{array}{c}0.27 \\
{[.255]}\end{array}$ & $\begin{array}{c}0.29 \\
{[.264]}\end{array}$ \\
\hline Student & $\begin{array}{c}0.21 \\
{[.375]}\end{array}$ & $\begin{array}{c}0.24 \\
{[.275]}\end{array}$ & $\begin{array}{c}0.23 \\
{[.325]}\end{array}$ & $\begin{array}{c}0.21 \\
{[.350]}\end{array}$ & $\begin{array}{c}0.18 \\
{[.423]}\end{array}$ & $\begin{array}{c}0.19 \\
{[.426]}\end{array}$ & $\begin{array}{c}0.13 \\
{[.537]}\end{array}$ & $\begin{array}{c}0.16 \\
{[.459]}\end{array}$ & $\begin{array}{c}0.22 \\
{[.396]}\end{array}$ & $\begin{array}{c}0.23 \\
{[.355]}\end{array}$ & $\begin{array}{c}0.24 \\
{[.351]}\end{array}$ \\
\hline Homemaker & $\begin{array}{c}0.31 \\
{[.168]}\end{array}$ & $\begin{array}{c}0.40^{\mathrm{c}} \\
{[.060]}\end{array}$ & $\begin{array}{c}0.29 \\
{[.213]}\end{array}$ & $\begin{array}{l}\mathbf{0 . 3 9}^{\mathbf{c}} \\
{[.080]}\end{array}$ & $\begin{array}{c}0.22 \\
{[.307]}\end{array}$ & $\begin{array}{c}0.47^{\mathrm{c}} \\
{[.050]}\end{array}$ & $\begin{array}{c}0.27 \\
{[.201]}\end{array}$ & $\begin{array}{c}0.21 \\
{[.330]}\end{array}$ & $\begin{array}{c}0.20 \\
{[.456]}\end{array}$ & $\begin{array}{c}0.32 \\
{[.190]}\end{array}$ & $\begin{array}{c}0.41 \\
{[.114]}\end{array}$ \\
\hline Unemployed & $\begin{array}{c}\mathbf{0 . 3 7}^{\mathrm{c}} \\
{[.086]}\end{array}$ & $\begin{array}{c}\mathbf{0 . 3 4}^{\mathrm{c}} \\
{[.095]}\end{array}$ & $\begin{array}{c}0.36 \\
{[.104]}\end{array}$ & $\begin{array}{l}\mathbf{0 . 3 5}^{\mathrm{c}} \\
{[.099]}\end{array}$ & $\begin{array}{c}0.29 \\
{[.164]}\end{array}$ & $\begin{array}{c}\mathbf{0 . 3 9}^{\mathrm{c}} \\
{[.088]}\end{array}$ & $\begin{array}{c}0.33 \\
{[.105]}\end{array}$ & $\begin{array}{c}0.29 \\
{[.152]}\end{array}$ & $\begin{array}{c}0.39 \\
{[.109]}\end{array}$ & $\begin{array}{c}0.28 \\
{[.222]}\end{array}$ & $\begin{array}{c}0.28 \\
{[.255]}\end{array}$ \\
\hline Age & $\begin{array}{c}\mathbf{- 0 . 0 1}^{\mathrm{b}} \\
{[.025]}\end{array}$ & $\begin{array}{l}\mathbf{- 0 . 0 1}^{\mathrm{b}} \\
{[.018]}\end{array}$ & $\begin{array}{l}-0.01^{\mathrm{b}} \\
{[.028]}\end{array}$ & $\begin{array}{l}-\mathbf{- 0 . 0 1}^{\mathrm{b}} \\
{[.048]}\end{array}$ & $\begin{array}{l}\mathbf{- 0 . 0 1}^{\mathrm{c}} \\
{[.074]}\end{array}$ & $\begin{array}{l}-0.01^{b} \\
{[.014]}\end{array}$ & $\begin{array}{l}-0.01^{\mathrm{c}} \\
{[.056]}\end{array}$ & $\begin{array}{l}\mathbf{- 0 . 0 1}^{\mathrm{b}} \\
{[.022]}\end{array}$ & $\begin{array}{l}-\mathbf{C . 0 1}^{\mathrm{b}} \\
{[.025]}\end{array}$ & $\begin{array}{c}0.00 \\
{[.224]}\end{array}$ & $\begin{array}{c}0.00 \\
{[.195]}\end{array}$ \\
\hline Gender & $\begin{array}{l}-0.06 \\
{[.448]}\end{array}$ & $\begin{array}{c}-0.08 \\
{[.282]}\end{array}$ & $\begin{array}{c}-0.06 \\
{[.316]}\end{array}$ & $\begin{array}{l}-0.05 \\
{[.450]}\end{array}$ & $\begin{array}{c}-0.07 \\
{[.277]}\end{array}$ & $\begin{array}{c}-0.14 \\
{[.114]}\end{array}$ & $\begin{array}{c}-0.02 \\
{[.798]}\end{array}$ & $\begin{array}{c}-0.04 \\
{[.501]}\end{array}$ & $\begin{array}{c}-0.07 \\
{[.328]}\end{array}$ & $\begin{array}{c}-0.09 \\
{[.181]}\end{array}$ & $\begin{array}{c}-0.07 \\
{[.312]}\end{array}$ \\
\hline $\begin{array}{l}\text { Correction } \\
\text { variable }\end{array}$ & $\begin{array}{l}-0.26 \\
{[.492]}\end{array}$ & $\begin{array}{c}-0.35 \\
{[.321]}\end{array}$ & $\begin{array}{c}-0.37 \\
{[.277]}\end{array}$ & $\begin{array}{c}-0.10 \\
{[.715]}\end{array}$ & $\begin{array}{c}-0.31 \\
{[.301]}\end{array}$ & $\begin{array}{c}-0.38 \\
{[.368]}\end{array}$ & $\begin{array}{c}0.03 \\
{[.937]}\end{array}$ & $\begin{array}{l}-0.28 \\
{[.434]}\end{array}$ & $\begin{array}{l}-0.86^{b} \\
{[.028]}\end{array}$ & $\begin{array}{c}-0.13 \\
{[.635]}\end{array}$ & $\begin{array}{c}-0.36 \\
{[.243]}\end{array}$ \\
\hline
\end{tabular}

\footnotetext{
${ }^{9}$ No fight is the perceived unwillingness of the government to fight corruption
} 
Table 7.

Equation-by-equation estimates

Corruption perception equation (equation 4b)

\begin{tabular}{|c|c|c|c|c|c|c|c|c|c|c|c|}
\hline $\begin{array}{l}\text { Institution } \\
\text { Parameter }\end{array}$ & $\begin{array}{c}\text { Central } \\
\text { Govt. }\end{array}$ & $\begin{array}{l}\text { Local } \\
\text { Govt. }\end{array}$ & $\begin{array}{l}\text { Juridic. } \\
\text { Instit. }\end{array}$ & $\begin{array}{l}\text { Inspec- } \\
\text { tions }\end{array}$ & Police & Army & $\begin{array}{l}\text { Educat. } \\
\text { Establ. }\end{array}$ & $\begin{array}{l}\text { Medic. } \\
\text { Establ. }\end{array}$ & $\begin{array}{c}\text { State } \\
\text { TV }\end{array}$ & $\begin{array}{l}\text { Privat. } \\
\text { Author. }\end{array}$ & Banks \\
\hline Constant & $\begin{array}{c}2.15^{\mathrm{a}} \\
{[.000]}\end{array}$ & $\begin{array}{c}1.65^{\mathrm{a}} \\
{[.000]}\end{array}$ & $\begin{array}{c}2.31^{\mathrm{a}} \\
{[.000]}\end{array}$ & $\begin{array}{l}2.59^{\mathrm{a}} \\
{[.000]}\end{array}$ & $\begin{array}{c}2.09^{\mathrm{a}} \\
{[.000]}\end{array}$ & $\begin{array}{c}1.10^{\mathrm{a}} \\
{[.002]}\end{array}$ & $\begin{array}{l}1.62^{\mathrm{a}} \\
{[.000]}\end{array}$ & $\begin{array}{l}1.97^{\mathrm{a}} \\
{[.000]}\end{array}$ & $\begin{array}{l}1.60^{\mathrm{a}} \\
{[.000]}\end{array}$ & $\begin{array}{l}1.33^{\mathrm{a}} \\
{[.000]}\end{array}$ & \\
\hline $\begin{array}{l}\text { Frequency of } \\
\text { Visits }=1\end{array}$ & $\begin{array}{c}0.04 \\
{[.856]}\end{array}$ & $\begin{array}{l}-0.04 \\
{[.570]}\end{array}$ & $\begin{array}{c}0.13 \\
{[.211]}\end{array}$ & $\begin{array}{c}0.03 \\
{[.694]}\end{array}$ & $\begin{array}{c}0.16^{b} \\
{[.036]}\end{array}$ & $\begin{array}{c}0.09 \\
{[.565]}\end{array}$ & $\begin{array}{l}-0.07 \\
{[.328]}\end{array}$ & $\begin{array}{l}-0.09 \\
{[.207]}\end{array}$ & $\begin{array}{c}0.17 \\
{[.573]}\end{array}$ & $\begin{array}{l}-0.37^{\mathrm{a}} \\
{[.000]}\end{array}$ & $\begin{array}{l}-0.25^{\mathrm{c}} \\
{[.060]}\end{array}$ \\
\hline $\begin{array}{l}\text { Frequency of } \\
\text { Visits }=2\end{array}$ & $\begin{array}{l}- \\
-\end{array}$ & $\begin{array}{c}0.10 \\
{[.355]}\end{array}$ & $\begin{array}{l}- \\
-\end{array}$ & $\begin{array}{l}- \\
-\end{array}$ & $\begin{array}{l}- \\
- \\
\end{array}$ & $\begin{array}{l}- \\
-\end{array}$ & $\begin{array}{c}-0.01 \\
{[.915]}\end{array}$ & $\begin{array}{l}-0.13 \\
{[.106]}\end{array}$ & $\begin{array}{l}- \\
-\end{array}$ & $\begin{array}{l}-0.08 \\
{[.753]}\end{array}$ & $\begin{array}{l}-0.26 \\
{[.160]}\end{array}$ \\
\hline $\begin{array}{l}\text { Frequency of } \\
\text { Visits=3 } \\
\end{array}$ & $\begin{array}{l}- \\
-\end{array}$ & - & - & - & - & - & - & & - & - & $\begin{array}{l}-0.28 \\
{[.221]}\end{array}$ \\
\hline Press $=1$ & $\begin{array}{l}-0.41^{\mathrm{c}} \\
{[.093]}\end{array}$ & $\begin{array}{l}-0.80^{\mathrm{a}} \\
{[.000]}\end{array}$ & $\begin{array}{l}-0.70^{\mathrm{a}} \\
{[.007]}\end{array}$ & $\begin{array}{c}-0.12 \\
{[.660]}\end{array}$ & $\begin{array}{c}-0.37 \\
{[.137]} \\
\end{array}$ & $\begin{array}{l}-0.64^{\mathrm{a}} \\
{[.006]}\end{array}$ & $\begin{array}{c}-0.07 \\
{[.732]}\end{array}$ & $\begin{array}{l}-0.51^{b} \\
{[.035]}\end{array}$ & $\begin{array}{l}-0.51^{b} \\
{[.046]}\end{array}$ & $\begin{array}{l}-0.44^{\mathrm{c}} \\
{[.073]}\end{array}$ & $\begin{array}{l}-0.54^{b} \\
{[.031]}\end{array}$ \\
\hline Press $=2$ & $\begin{array}{l}-0.56^{\mathrm{b}} \\
{[.049]}\end{array}$ & $\begin{array}{l}-0.78^{\mathrm{a}} \\
{[.004]}\end{array}$ & $\begin{array}{l}-0.69^{\mathbf{b}} \\
{[.020]}\end{array}$ & & & & & & & & \\
\hline Press $=3$ & $\begin{array}{l}-0.44^{\mathrm{c}} \\
{[.098]}\end{array}$ & $\begin{array}{l}-0.65^{\mathrm{b}} \\
{[.011]}\end{array}$ & $\begin{array}{l}-0.82^{\mathrm{a}} \\
{[.004]}\end{array}$ & & & & $\begin{array}{c}0.17 \\
{[.461]}\end{array}$ & & $\begin{array}{l}-0.34 \\
{[.249]}\end{array}$ & $\begin{array}{l}-0.47^{\mathrm{c}} \\
{[.091]}\end{array}$ & $\begin{array}{l}-0.64^{b} \\
{[.024]}\end{array}$ \\
\hline Press $=4$ & $\begin{array}{l}-0.57^{\mathrm{b}} \\
{[.027]}\end{array}$ & & $\begin{array}{l}-0.78^{\mathrm{a}} \\
{[.004]}\end{array}$ & & & & & & & & \\
\hline Press $=5$ & $\begin{array}{l}-0.55^{\mathrm{c}} \\
{[.051]}\end{array}$ & $\begin{array}{l}-0.75^{\mathrm{a}} \\
{[.006]}\end{array}$ & $\begin{array}{l}-\mathbf{- 0 . 6 9 ^ { b }} \\
{[.019]}\end{array}$ & $\begin{array}{l}-0.18 \\
{[.545]}\end{array}$ & & & $\begin{array}{l}-0.26 \\
{[.287]}\end{array}$ & & $\begin{array}{l}-0.48 \\
{[.118]}\end{array}$ & $\begin{array}{l}-0.59^{b} \\
{[.039]} \\
\end{array}$ & $\begin{array}{l}-0.54^{\mathrm{c}} \\
{[.075]}\end{array}$ \\
\hline $\mathrm{TV}=1$ & & $\begin{array}{l}-0.23 \\
{[.228]}\end{array}$ & $\begin{array}{l}-0.24 \\
{[.287]} \\
\end{array}$ & & & & & & & & \\
\hline $\mathrm{TV}=2$ & $\begin{array}{c}0.29 \\
{[.287]}\end{array}$ & $\begin{array}{c}0.33 \\
{[.158]}\end{array}$ & & & & & & & & & \\
\hline $\mathrm{TV}=3$ & & $\begin{array}{c}-0.21 \\
{[.336]}\end{array}$ & & & & & & & & & \\
\hline $\mathrm{TV}=4$ & & $\begin{array}{l}-0.11 \\
{[.613]}\end{array}$ & & $\begin{array}{l}-0.50^{b} \\
{[.045]}\end{array}$ & & & & & $\begin{array}{c}0.01 \\
{[.971]}\end{array}$ & & \\
\hline $\mathrm{TV}=5$ & $\begin{array}{l}-0.30 \\
{[.247]}\end{array}$ & $\begin{array}{c}-0.23 \\
{[.328]}\end{array}$ & $\begin{array}{l}-0.15 \\
{[.568]}\end{array}$ & & $\begin{array}{c}0.01 \\
{[.957]}\end{array}$ & & $\begin{array}{c}0.08 \\
{[.720]}\end{array}$ & & $\begin{array}{l}-0.10 \\
{[.739]}\end{array}$ & $\begin{array}{l}-0.29 \\
{[.265]}\end{array}$ & \\
\hline Radio $=1$ & & $\begin{array}{c}0.26 \\
{[.375]}\end{array}$ & & & & & & $\begin{array}{c}0.28 \\
{[.306]}\end{array}$ & $\begin{array}{l}-0.20 \\
{[.501]}\end{array}$ & $\begin{array}{c}0.23 \\
{[.448]}\end{array}$ & \\
\hline Radio $=2$ & $\begin{array}{c}0.13 \\
{[.697]}\end{array}$ & $\begin{array}{c}0.12 \\
{[.729]}\end{array}$ & $\begin{array}{l}-0.28 \\
{[.445]}\end{array}$ & $\begin{array}{l}-0.36 \\
{[.343]}\end{array}$ & $\begin{array}{l}-0.10 \\
{[.784]}\end{array}$ & $\begin{array}{l}-0.15 \\
{[.635]}\end{array}$ & $\begin{array}{c}0.16 \\
{[.580]}\end{array}$ & $\begin{array}{c}0.40 \\
{[.218]}\end{array}$ & $\begin{array}{l}-0.8 \\
{[.01}\end{array}$ & $\begin{array}{c}0.35 \\
{[.327]}\end{array}$ & $\begin{array}{l}-0.14 \\
{[.689]}\end{array}$ \\
\hline Radio $=3$ & & $\begin{array}{c}0.10 \\
{[.755]}\end{array}$ & & & $\begin{array}{l}-0.28 \\
{[.407]}\end{array}$ & & $\begin{array}{c}0.04 \\
{[.881]}\end{array}$ & $\begin{array}{c}0.47 \\
{[.134]}\end{array}$ & & $\begin{array}{c}0.18 \\
{[.588]}\end{array}$ & \\
\hline Radio $=4$ & $\begin{array}{c}0.36 \\
{[.226]}\end{array}$ & $\begin{array}{c}0.21 \\
{[.504]}\end{array}$ & $\begin{array}{l}-0.48 \\
{[.166]}\end{array}$ & $\begin{array}{l}-0.36 \\
{[.313]}\end{array}$ & $\begin{array}{c}-0.26 \\
{[.436]}\end{array}$ & $\begin{array}{l}-0.15 \\
{[.604]}\end{array}$ & $\begin{array}{c}-0.02 \\
{[.928]}\end{array}$ & $\begin{array}{c}0.12 \\
{[.679]}\end{array}$ & $\begin{array}{l}-0.06 \\
{[.855]}\end{array}$ & $\begin{array}{c}0.32 \\
{[.330]}\end{array}$ & $\begin{array}{c}-0.12 \\
{[.714]}\end{array}$ \\
\hline Radio $=5$ & $\begin{array}{c}0.01 \\
{[.985]}\end{array}$ & $\begin{array}{c}0.32 \\
{[.368]}\end{array}$ & & $\begin{array}{l}-0.47 \\
{[.222]}\end{array}$ & \begin{tabular}{|l|}
-0.12 \\
{$[.752]$}
\end{tabular} & $\begin{array}{l}-0.30 \\
{[.378]}\end{array}$ & $\begin{array}{c}-0.21 \\
{[.491]}\end{array}$ & $\begin{array}{c}0.37 \\
{[.267]}\end{array}$ & & $\begin{array}{c}0.21 \\
{[.554]}\end{array}$ & $\begin{array}{c}-0.01 \\
{[.974]}\end{array}$ \\
\hline riends & $\begin{array}{c}0.01 \\
{[.903]}\end{array}$ & $\begin{array}{c}0.00 \\
{[.938]}\end{array}$ & $\begin{array}{c}0.00 \\
{[.973]}\end{array}$ & $\begin{array}{l}-0.06 \\
{[.341]}\end{array}$ & $\begin{array}{c}0.05 \\
{[.420]}\end{array}$ & $\begin{array}{c}0.05 \\
{[.465]}\end{array}$ & $\begin{array}{c}0.01 \\
{[.854]}\end{array}$ & $\begin{array}{c}0.03 \\
{[.613]}\end{array}$ & $\begin{array}{l}-0.08 \\
{[.300]}\end{array}$ & $\begin{array}{c}0.00 \\
{[.982]}\end{array}$ & $\begin{array}{l}-0.06 \\
{[.355]}\end{array}$ \\
\hline Strangers & $\begin{array}{l}-0.02 \\
{[.766]}\end{array}$ & $\begin{array}{c}0.00 \\
{[.955]}\end{array}$ & $\begin{array}{c}0.15^{\mathrm{c}} \\
{[.056]}\end{array}$ & $\begin{array}{c}0.05 \\
{[.548]}\end{array}$ & $\begin{array}{c}0.24^{\mathrm{a}} \\
{[.005]}\end{array}$ & $\begin{array}{c}0.03 \\
{[.710]}\end{array}$ & $\begin{array}{c}0.11 \\
{[.129]}\end{array}$ & $\begin{array}{c}0.22^{\mathrm{a}} \\
{[.006]}\end{array}$ & $\begin{array}{c}0.02 \\
{[.862]}\end{array}$ & $\begin{array}{c}-0.11 \\
{[.169]}\end{array}$ & $\begin{array}{c}0.06 \\
{[.466]}\end{array}$ \\
\hline Experience & $\begin{array}{l}0.14^{\mathrm{c}} \\
{[.051]}\end{array}$ & $\begin{array}{l}0_{0.15^{\mathrm{b}}} \\
{[.031]}\end{array}$ & $\begin{array}{c}0.28^{\mathrm{a}} \\
{[.000]}\end{array}$ & $\begin{array}{l}0^{0.18}{ }^{b} \\
{[.010]}\end{array}$ & $\begin{array}{c}0.27^{\mathrm{a}} \\
{[.000]}\end{array}$ & $\begin{array}{c}0.26^{\mathrm{a}} \\
{[.000]}\end{array}$ & $\begin{array}{l}0.26^{\mathrm{a}} \\
{[.000]}\end{array}$ & $\begin{array}{l}0.25^{\mathrm{a}} \\
{[.000]}\end{array}$ & $\begin{array}{l}0.19^{b} \\
{[.022]}\end{array}$ & $\begin{array}{l}0.32^{\mathrm{a}} \\
{[.000]}\end{array}$ & $\begin{array}{l}0.18^{b} \\
{[.020]}\end{array}$ \\
\hline
\end{tabular}


Table 7 continued

\begin{tabular}{|c|c|c|c|c|c|c|c|c|c|c|c|}
\hline \begin{tabular}{|l|} 
Institution \\
Parameter
\end{tabular} & $\begin{array}{c}\text { Central } \\
\text { Govt. }\end{array}$ & $\begin{array}{l}\text { Local } \\
\text { Govt. }\end{array}$ & $\begin{array}{l}\text { Juridic. } \\
\text { Instit. }\end{array}$ & $\begin{array}{c}\text { Inspec- } \\
\text { tions }\end{array}$ & Police & Army & $\begin{array}{l}\text { Educat. } \\
\text { Establ. }\end{array}$ & $\begin{array}{l}\text { Medic. } \\
\text { Establ. }\end{array}$ & $\begin{array}{c}\text { State } \\
\text { TV }\end{array}$ & $\begin{array}{c}\text { Privat. } \\
\text { Author. }\end{array}$ & Banks \\
\hline Town size 2 & $\begin{array}{c}0.20^{\mathrm{c}} \\
{[.054]} \\
\end{array}$ & $\begin{array}{l}0.32^{\mathrm{a}} \\
{[.005]}\end{array}$ & $\begin{array}{l}0.35^{\mathrm{a}} \\
{[.001]} \\
\end{array}$ & $\begin{array}{c}0.15 \\
{[.154]} \\
\end{array}$ & $\begin{array}{c}0.26^{b} \\
{[.017]} \\
\end{array}$ & $\begin{array}{c}0.33^{\mathrm{a}} \\
{[.003]}\end{array}$ & $\begin{array}{c}0.30^{\mathrm{a}} \\
{[.002]} \\
\end{array}$ & $\begin{array}{l}0.24^{b} \\
{[.021]}\end{array}$ & $\begin{array}{l}0.53^{\mathrm{a}} \\
{[.000]}\end{array}$ & $\begin{array}{l}0.21^{\mathrm{c}} \\
{[.071]}\end{array}$ & $\begin{array}{c}0.20^{c} \\
{[.086]}\end{array}$ \\
\hline Town size 3 & $\begin{array}{c}0.49^{\mathrm{a}} \\
{[.000]}\end{array}$ & $\begin{array}{l}0.63^{\mathrm{a}} \\
{[.000]}\end{array}$ & $\begin{array}{l}0.49^{\mathrm{a}} \\
{[.000]}\end{array}$ & $\begin{array}{l}0.51^{\mathrm{a}} \\
{[.000]}\end{array}$ & $\begin{array}{l}0.33^{\mathrm{a}} \\
{[.001]}\end{array}$ & $\begin{array}{c}0.36^{\mathrm{a}} \\
{[.000]}\end{array}$ & $\begin{array}{c}0.39^{\mathrm{a}} \\
{[.000]}\end{array}$ & $\begin{array}{c}0.33^{\mathrm{a}} \\
{[.000]}\end{array}$ & $\begin{array}{l}0.64^{\mathrm{a}} \\
{[.000]}\end{array}$ & $\begin{array}{c}0.47^{\mathrm{a}} \\
{[.000]}\end{array}$ & $\begin{array}{c}0.34^{\mathrm{a}} \\
{[.001]}\end{array}$ \\
\hline Town size 4 & $\begin{array}{c}-0.01 \\
{[.951]}\end{array}$ & $\begin{array}{c}0.38^{\mathrm{a}} \\
{[.000]}\end{array}$ & $\begin{array}{l}-0.05 \\
{[.614]}\end{array}$ & $\begin{array}{c}-0.02 \\
{[.840]}\end{array}$ & $\begin{array}{c}-0.13 \\
{[.141]}\end{array}$ & $\begin{array}{c}0.02 \\
{[.831]}\end{array}$ & $\begin{array}{c}-0.01 \\
{[.884]}\end{array}$ & $\begin{array}{l}-0.15^{\mathrm{c}} \\
{[.082]}\end{array}$ & $\begin{array}{c}0.17 \\
{[.110]}\end{array}$ & $\begin{array}{l}-0.09 \\
{[.384]}\end{array}$ & $\begin{array}{l}-0.18 \\
{[.084]}\end{array}$ \\
\hline Town size 5 & $\begin{array}{l}0.35^{\mathrm{a}} \\
{[.000]}\end{array}$ & $\begin{array}{c}0.58^{\mathrm{a}} \\
{[.000]}\end{array}$ & $\begin{array}{l}0.47^{\mathrm{a}} \\
{[.000]}\end{array}$ & $\begin{array}{l}0.52^{\mathrm{a}} \\
{[.000]}\end{array}$ & $\begin{array}{l}0.49^{\mathrm{a}} \\
{[.000]}\end{array}$ & $\begin{array}{l}0.27^{\mathrm{a}} \\
{[.002]}\end{array}$ & $\begin{array}{l}0.26^{\mathrm{a}} \\
{[.001]}\end{array}$ & $\begin{array}{c}0.04 \\
{[.658]}\end{array}$ & $\begin{array}{c}0.88^{\mathrm{a}} \\
{[.000]}\end{array}$ & $\begin{array}{c}0.27^{\mathrm{a}} \\
{[.003]}\end{array}$ & $\begin{array}{c}0.24^{b} \\
{[.010]}\end{array}$ \\
\hline Peasant & $\begin{array}{l}-0.07 \\
{[.788]}\end{array}$ & $\begin{array}{c}0.14 \\
{[.591]}\end{array}$ & $\begin{array}{c}-0.19 \\
{[.471]}\end{array}$ & $\begin{array}{c}0.31 \\
{[.221]}\end{array}$ & $\begin{array}{c}0.23 \\
{[.361]}\end{array}$ & $\begin{array}{c}0.13 \\
{[.634]}\end{array}$ & $\begin{array}{l}-0.42^{c} \\
{[.065]}\end{array}$ & $\begin{array}{l}-0.43^{\mathrm{c}} \\
{[.078]}\end{array}$ & $\begin{array}{l}-0.19 \\
{[.511]}\end{array}$ & $\begin{array}{c}0.11 \\
{[.689]} \\
\end{array}$ & $\begin{array}{r}-0.14 \\
{[.622]} \\
\end{array}$ \\
\hline Worker & $\begin{array}{c}-0.04 \\
{[.835]}\end{array}$ & $\begin{array}{c}0.34 \\
{[.114]}\end{array}$ & $\begin{array}{c}-0.02 \\
{[.926]}\end{array}$ & $\begin{array}{c}0.32 \\
{[.124]}\end{array}$ & $\begin{array}{c}0.47^{b} \\
{[.019]}\end{array}$ & $\begin{array}{c}0.12 \\
{[.579]}\end{array}$ & $\begin{array}{c}0.11 \\
{[.573]}\end{array}$ & $\begin{array}{c}0.05 \\
{[.803]}\end{array}$ & $\begin{array}{c}-0.29 \\
{[.219]}\end{array}$ & $\begin{array}{c}0.25 \\
{[.253]}\end{array}$ & $\begin{array}{c}0.11 \\
{[.654]}\end{array}$ \\
\hline Clerk & $\begin{array}{c}-0.25 \\
{[.248]}\end{array}$ & $\begin{array}{c}0.24 \\
{[.275]}\end{array}$ & $\begin{array}{c}-0.11 \\
{[.607]}\end{array}$ & $\begin{array}{c}0.02 \\
{[.908]}\end{array}$ & $\begin{array}{c}0.15 \\
{[.455]}\end{array}$ & $\begin{array}{c}-0.06 \\
{[.795]}\end{array}$ & $\begin{array}{c}0.08 \\
{[.676]}\end{array}$ & $\begin{array}{c}-0.02 \\
{[.940]}\end{array}$ & $\begin{array}{c}-0.35 \\
{[.150]}\end{array}$ & $\begin{array}{c}0.12 \\
{[.582]}\end{array}$ & $\begin{array}{c}-0.04 \\
{[.858]}\end{array}$ \\
\hline Specialist & $\begin{array}{c}-0.31 \\
{[.164]}\end{array}$ & $\begin{array}{c}0.21 \\
{[.346]}\end{array}$ & $\begin{array}{c}-0.28 \\
{[.209]}\end{array}$ & $\begin{array}{c}0.21 \\
{[.322]}\end{array}$ & $\begin{array}{c}0.18 \\
{[.376]}\end{array}$ & $\begin{array}{c}0.13 \\
{[.563]}\end{array}$ & $\begin{array}{c}-0.20 \\
{[.292]}\end{array}$ & $\begin{array}{c}-0.12 \\
{[.575]}\end{array}$ & $\begin{array}{l}-0.43^{c} \\
{[.078]}\end{array}$ & $\begin{array}{c}0.31 \\
{[.177]}\end{array}$ & $\begin{array}{c}-0.01 \\
{[.962]}\end{array}$ \\
\hline Businesman & $\begin{array}{c}-0.07 \\
{[.799]}\end{array}$ & $\begin{array}{c}0.32 \\
{[.225]}\end{array}$ & $\begin{array}{c}0.02 \\
{[.932]}\end{array}$ & $\begin{array}{c}0.36 \\
{[.146]}\end{array}$ & $\begin{array}{c}0.21 \\
{[.403]}\end{array}$ & $\begin{array}{c}-0.01 \\
{[.967]}\end{array}$ & $\begin{array}{c}-0.08 \\
{[.709]}\end{array}$ & $\begin{array}{c}-0.35 \\
{[.157]}\end{array}$ & $\begin{array}{c}-0.31 \\
{[.272]}\end{array}$ & $\begin{array}{c}0.06 \\
{[.831]}\end{array}$ & $\begin{array}{c}-0.07 \\
{[.801]}\end{array}$ \\
\hline Retired & $\begin{array}{c}-0.30 \\
{[.191]}\end{array}$ & $\begin{array}{c}0.31 \\
{[.178]}\end{array}$ & $\begin{array}{c}-0.26 \\
{[.256]}\end{array}$ & $\begin{array}{c}0.15 \\
{[.488]}\end{array}$ & $\begin{array}{c}0.30 \\
{[.163]}\end{array}$ & $\begin{array}{c}0.09 \\
{[.703]}\end{array}$ & $\begin{array}{c}-0.06 \\
{[.756]}\end{array}$ & $\begin{array}{c}-0.16 \\
{[.465]}\end{array}$ & $\begin{array}{c}-0.31 \\
{[.219]}\end{array}$ & $\begin{array}{c}0.10 \\
{[.674]}\end{array}$ & $\begin{array}{l}-0.25 \\
{[.321]}\end{array}$ \\
\hline Student & $\begin{array}{c}-0.27 \\
{[.256]}\end{array}$ & $\begin{array}{c}0.07 \\
{[.777]}\end{array}$ & $\begin{array}{c}-0.27 \\
{[.242]}\end{array}$ & $\begin{array}{c}0.12 \\
{[.581]}\end{array}$ & $\begin{array}{c}0.27 \\
{[.219]}\end{array}$ & $\begin{array}{c}-0.11 \\
{[.632]}\end{array}$ & $\begin{array}{c}0.08 \\
{[.693]}\end{array}$ & $\begin{array}{c}-0.31 \\
{[.177]}\end{array}$ & $\begin{array}{c}-0.18 \\
{[.484]}\end{array}$ & $\begin{array}{c}0.04 \\
{[.885]}\end{array}$ & $\begin{array}{c}-0.04 \\
{[.875]}\end{array}$ \\
\hline Homemaker & $\begin{array}{c}-0.28 \\
{[.225]}\end{array}$ & $\begin{array}{c}0.22 \\
{[.332]}\end{array}$ & $\begin{array}{c}-0.09 \\
{[.700]}\end{array}$ & $\begin{array}{c}0.02 \\
{[.927]}\end{array}$ & $\begin{array}{c}0.29 \\
{[.186]}\end{array}$ & $\begin{array}{c}0.21 \\
{[.373]}\end{array}$ & $\begin{array}{c}0.12 \\
{[.551]}\end{array}$ & $\begin{array}{c}0.07 \\
{[.759]}\end{array}$ & $\begin{array}{c}-0.25 \\
{[.345]}\end{array}$ & $\begin{array}{c}0.26 \\
{[.267]}\end{array}$ & $\begin{array}{c}0.03 \\
{[.895]}\end{array}$ \\
\hline Unemployed & $\begin{array}{c}-0.05 \\
{[.815]}\end{array}$ & $\begin{array}{c}0.38^{c} \\
{[.081]}\end{array}$ & $\begin{array}{c}-0.01 \\
{[.963]}\end{array}$ & $\begin{array}{c}0.32 \\
{[.130]}\end{array}$ & $\begin{array}{c}0.41^{b} \\
{[.046]}\end{array}$ & $\begin{array}{c}0.10 \\
{[.659]}\end{array}$ & $\begin{array}{c}-0.06 \\
{[.757]}\end{array}$ & $\begin{array}{c}-0.16 \\
{[.457]}\end{array}$ & $\begin{array}{c}-0.26 \\
{[.280]}\end{array}$ & $\begin{array}{c}0.28 \\
{[.219]}\end{array}$ & $\begin{array}{c}0.07 \\
{[.786]}\end{array}$ \\
\hline Age & $\begin{array}{c}0.01^{\mathrm{a}} \\
{[.000]}\end{array}$ & $\begin{array}{c}0.00 \\
{[.148]}\end{array}$ & $\begin{array}{c}0.011^{\mathrm{a}} \\
{[.001]}\end{array}$ & $\begin{array}{c}0.00 \\
{[.480]}\end{array}$ & $\begin{array}{c}0.01^{b} \\
{[.042]}\end{array}$ & $\begin{array}{c}0.00 \\
{[.828]}\end{array}$ & $\begin{array}{c}0.00 \\
{[.542]}\end{array}$ & $\begin{array}{c}0.01^{b} \\
{[.032]}\end{array}$ & $\begin{array}{c}0.01^{\mathrm{a}} \\
{[.001]}\end{array}$ & $\begin{array}{c}0.01^{\mathrm{a}} \\
{[.000]}\end{array}$ & $\begin{array}{c}0.02^{\mathrm{a}} \\
{[.000]}\end{array}$ \\
\hline Gender & $\begin{array}{c}0.14^{\mathrm{c}} \\
{[.052]}\end{array}$ & $\begin{array}{c}0.11 \\
{[.131]}\end{array}$ & $\begin{array}{c}0.04 \\
{[.531]}\end{array}$ & $\begin{array}{c}0.01 \\
{[.941]}\end{array}$ & $\begin{array}{c}0.02 \\
{[.738]}\end{array}$ & $\begin{array}{c}0.01 \\
{[.908]}\end{array}$ & $\begin{array}{c}0.01 \\
{[.878]}\end{array}$ & $\begin{array}{c}-0.07 \\
{[.277]}\end{array}$ & $\begin{array}{c}0.02 \\
{[.751]}\end{array}$ & $\begin{array}{c}-0.10 \\
{[.147]}\end{array}$ & $\begin{array}{c}-0.04 \\
{[.557]}\end{array}$ \\
\hline $\begin{array}{l}\text { Correction } \\
\text { variable }\end{array}$ & $\begin{array}{c}0.40 \\
{[.288]}\end{array}$ & $\begin{array}{c}0.48 \\
{[.193]}\end{array}$ & $\begin{array}{c}-0.17 \\
{[.613]}\end{array}$ & $\begin{array}{l}-0.20 \\
{[.467]}\end{array}$ & $\begin{array}{c}0.30 \\
{[.364]}\end{array}$ & $\begin{array}{l}-0.81^{\mathrm{c}} \\
{[.069]}\end{array}$ & $\begin{array}{c}-0.19 \\
{[.569]}\end{array}$ & $\begin{array}{c}-0.27 \\
{[.513]}\end{array}$ & $\begin{array}{c}0.61 \\
{[.157]}\end{array}$ & $\begin{array}{c}-0.03 \\
{[.928]}\end{array}$ & $\begin{array}{c}-0.34 \\
{[.291]}\end{array}$ \\
\hline
\end{tabular}


Table 8. Joint Estimation, Willingness to give bribe equation (equation 4a)

\begin{tabular}{|c|c|c|c|c|c|c|c|c|c|c|c|}
\hline \begin{tabular}{|l|} 
Institution \\
Parameter
\end{tabular} & $\begin{array}{c}\text { Central } \\
\text { Govt. }\end{array}$ & $\begin{array}{l}\text { Local } \\
\text { Govt. }\end{array}$ & $\begin{array}{l}\text { Juridic. } \\
\text { Instit. }\end{array}$ & $\begin{array}{c}\text { Inspec- } \\
\text { tions }\end{array}$ & Police & Army & $\begin{array}{l}\text { Educat. } \\
\text { Establ. }\end{array}$ & $\begin{array}{l}\text { Medic. } \\
\text { Establ. }\end{array}$ & $\begin{array}{c}\text { State } \\
\text { TV }\end{array}$ & $\begin{array}{l}\text { Privat. } \\
\text { Author. }\end{array}$ & Banks \\
\hline Constant & $\begin{array}{c}0.05 \\
{[.881]} \\
\end{array}$ & $\begin{array}{l}-1.55^{\mathrm{a}} \\
{[.000]}\end{array}$ & $\begin{array}{l}-1.79^{a} \\
{[.000]}\end{array}$ & $\begin{array}{c}0.17 \\
{[.551]} \\
\end{array}$ & $\begin{array}{l}-2.25^{\mathrm{a}} \\
{[.000]}\end{array}$ & $\begin{array}{l}-0.96^{a} \\
{[.005]}\end{array}$ & $\begin{array}{l}-2.15^{\mathrm{a}} \\
{[.000]}\end{array}$ & $\begin{array}{c}0.08 \\
{[.762]}\end{array}$ & $\begin{array}{l}-1.58^{a} \\
{[.000]}\end{array}$ & $\begin{array}{c}-2.69^{a} \\
{[.000]}\end{array}$ & $\begin{array}{l}-0.91^{b} \\
{[.011]}\end{array}$ \\
\hline $\begin{array}{l}\text { Corruption } \\
\text { Perception } 2\end{array}$ & $\begin{array}{l}-0.92^{\mathrm{a}} \\
{[.000]}\end{array}$ & $\begin{array}{l}1.05^{\mathrm{a}} \\
{[.000]}\end{array}$ & $\begin{array}{l}1.73^{\mathrm{a}} \\
{[.000]}\end{array}$ & $\begin{array}{l}-0.65^{b} \\
{[.014]}\end{array}$ & $\begin{array}{l}1.11^{\mathrm{a}} \\
{[.000]}\end{array}$ & $\begin{array}{l}1.11^{\mathrm{a}} \\
{[.000]}\end{array}$ & $\begin{array}{l}1.55^{\mathrm{a}} \\
{[.000]}\end{array}$ & $\begin{array}{l}-0.42^{b} \\
{[.028]}\end{array}$ & $\begin{array}{l}0.77^{\mathrm{a}} \\
{[.000]}\end{array}$ & $\begin{array}{l}1.95^{\mathrm{a}} \\
{[.000]}\end{array}$ & $\begin{array}{l}1.09^{\mathrm{a}} \\
{[.000]}\end{array}$ \\
\hline $\begin{array}{l}\text { Corruption } \\
\text { Perception } 3\end{array}$ & $\begin{array}{l}-0.34^{b} \\
{[.015]}\end{array}$ & $\begin{array}{l}1.50^{\mathrm{a}} \\
{[.000]}\end{array}$ & $\begin{array}{l}2.18^{\mathrm{a}} \\
{[.000]}\end{array}$ & $\begin{array}{l}-0.37^{b} \\
{[.016]}\end{array}$ & $\begin{array}{c}1.96^{\mathrm{a}} \\
{[.000]}\end{array}$ & $\begin{array}{c}1.46^{\mathrm{a}} \\
{[.000]}\end{array}$ & $\begin{array}{c}1.87^{\mathrm{a}} \\
{[.000]}\end{array}$ & $\begin{array}{c}-0.15 \\
{[.242]}\end{array}$ & $\begin{array}{l}1.37^{\mathrm{a}} \\
{[.000]}\end{array}$ & $\begin{array}{c}2.50^{\mathrm{a}} \\
{[.000]}\end{array}$ & $\begin{array}{l}1.21^{\mathrm{a}} \\
{[.000]}\end{array}$ \\
\hline $\begin{array}{l}\text { Corruption } \\
\text { Perception } 4\end{array}$ & $\begin{array}{c}0.14 \\
{[.344]}\end{array}$ & $\begin{array}{l}1.97^{\mathrm{a}} \\
{[.000]}\end{array}$ & $\begin{array}{l}2.66^{\mathrm{a}} \\
{[.000]}\end{array}$ & $\begin{array}{c}0.04 \\
{[.757]}\end{array}$ & $\begin{array}{l}2.47^{\mathrm{a}} \\
{[.000]}\end{array}$ & $\begin{array}{l}1.67^{\mathrm{a}} \\
{[.000]}\end{array}$ & $\begin{array}{l}2.59^{a} \\
{[.000]}\end{array}$ & $\begin{array}{l}-0.02 \\
{[.845]}\end{array}$ & $\begin{array}{l}1.81^{\mathrm{a}} \\
{[.000]}\end{array}$ & $\begin{array}{l}3.09^{a} \\
{[.000]}\end{array}$ & $\begin{array}{l}1.34^{\mathrm{a}} \\
{[.000]}\end{array}$ \\
\hline $\begin{array}{l}\text { Corruption } \\
\text { Perception } 5\end{array}$ & $\begin{array}{c}0.94^{\mathrm{a}} \\
{[.000]}\end{array}$ & $\begin{array}{l}2.93^{\mathrm{a}} \\
{[.000]}\end{array}$ & $\begin{array}{l}4.02^{\mathrm{a}} \\
{[.000]}\end{array}$ & $\begin{array}{c}0.95^{\mathrm{a}} \\
{[.000]}\end{array}$ & $\begin{array}{c}3.69^{\mathrm{a}} \\
{[.000]}\end{array}$ & $\begin{array}{l}1.81^{\mathrm{a}} \\
{[.000]}\end{array}$ & $\begin{array}{c}3.53^{\mathrm{a}} \\
{[.000]}\end{array}$ & $\begin{array}{l}0.87^{\mathrm{a}} \\
{[.000]}\end{array}$ & $\begin{array}{l}2.20^{\mathrm{a}} \\
{[.000]}\end{array}$ & $\begin{array}{l}4.07^{\mathrm{a}} \\
{[.000]}\end{array}$ & $\begin{array}{l}1.62^{\mathrm{a}} \\
{[.000]}\end{array}$ \\
\hline No fight $2^{10}$ & $\begin{array}{c}0.05 \\
{[.523]}\end{array}$ & $\begin{array}{c}0.05 \\
{[.513]}\end{array}$ & $\begin{array}{c}0.03 \\
{[.553]}\end{array}$ & $\begin{array}{c}0.00 \\
{[.984]}\end{array}$ & $\begin{array}{c}0.10 \\
{[.128]}\end{array}$ & $\begin{array}{c}0.11 \\
{[.277]}\end{array}$ & $\begin{array}{c}0.03 \\
{[.657]}\end{array}$ & $\begin{array}{c}0.04 \\
{[.644]}\end{array}$ & $\begin{array}{c}0.10 \\
{[.356]}\end{array}$ & $\begin{array}{c}0.03 \\
{[.344]}\end{array}$ & $\begin{array}{c}-0.01 \\
{[.897]}\end{array}$ \\
\hline No fight 3 & $\begin{array}{c}0.05 \\
{[.422]}\end{array}$ & $\begin{array}{c}0.02 \\
{[.733]}\end{array}$ & $\begin{array}{l}-0.01 \\
{[.758]}\end{array}$ & $\begin{array}{c}0.01 \\
{[.874]}\end{array}$ & $\begin{array}{c}0.01 \\
{[.836]}\end{array}$ & $\begin{array}{c}0.03 \\
{[.683]}\end{array}$ & $\begin{array}{l}-0.01 \\
{[.746]}\end{array}$ & $\begin{array}{c}0.03 \\
{[.652]}\end{array}$ & $\begin{array}{l}-0.02 \\
{[.825]}\end{array}$ & $\begin{array}{l}-0.01 \\
{[.578]}\end{array}$ & $\begin{array}{l}-0.07 \\
{[.444]}\end{array}$ \\
\hline No fight 4 & $\begin{array}{c}0.01 \\
{[.892]}\end{array}$ & $\begin{array}{l}-0.07 \\
{[.461]}\end{array}$ & $\begin{array}{l}-\mathbf{O . 0 8}^{\mathrm{c}} \\
{[.054]}\end{array}$ & $\begin{array}{l}-0.07 \\
{[.532]}\end{array}$ & $\begin{array}{c}0.00 \\
{[.990]}\end{array}$ & $\begin{array}{l}-0.01 \\
{[.954]}\end{array}$ & $\begin{array}{l}-0.07 \\
{[.408]}\end{array}$ & $\begin{array}{l}-0.07 \\
{[.503]}\end{array}$ & $\begin{array}{c}0.00 \\
{[.989]}\end{array}$ & $\begin{array}{l}-0.05 \\
{[.548]}\end{array}$ & $\begin{array}{l}-0.24 \\
{[.100]}\end{array}$ \\
\hline No fight 5 & $\begin{array}{c}0.06 \\
{[.573]}\end{array}$ & $\begin{array}{c}-0.11 \\
{[.294]}\end{array}$ & $\begin{array}{c}-0.06 \\
{[.105]}\end{array}$ & $\begin{array}{c}0.09 \\
{[.487]}\end{array}$ & $\begin{array}{c}-0.02 \\
{[.874]}\end{array}$ & $\begin{array}{c}0.06 \\
{[.676]}\end{array}$ & $\begin{array}{c}-0.13 \\
{[.144]}\end{array}$ & $\begin{array}{c}-0.10 \\
{[.415]}\end{array}$ & $\begin{array}{c}-0.06 \\
{[.690]}\end{array}$ & $\begin{array}{l}-0.13^{\mathrm{a}} \\
{[.000]}\end{array}$ & $\begin{array}{l}-0.13 \\
{[.461]}\end{array}$ \\
\hline Town size 2 & $\begin{array}{c}0.00 \\
{[.986]}\end{array}$ & $\begin{array}{c}-0.10 \\
{[.323]}\end{array}$ & $\begin{array}{c}-0.06 \\
{[.458]}\end{array}$ & $\begin{array}{c}-0.03 \\
{[.733]}\end{array}$ & $\begin{array}{c}-0.11 \\
{[.275]}\end{array}$ & $\begin{array}{c}-0.15 \\
{[.191]}\end{array}$ & $\begin{array}{c}-0.09 \\
{[.407]}\end{array}$ & $\begin{array}{c}-0.04 \\
{[.689]}\end{array}$ & $\begin{array}{l}-0.26^{c} \\
{[.087]}\end{array}$ & $\begin{array}{c}0.01 \\
{[.853]}\end{array}$ & $\begin{array}{l}-0.06 \\
{[.636]}\end{array}$ \\
\hline Town size 3 & $\begin{array}{c}-0.14 \\
{[.174]}\end{array}$ & $\begin{array}{l}-0.34^{\mathrm{a}} \\
{[.001]}\end{array}$ & $\begin{array}{l}-0.23^{\mathrm{a}} \\
{[.004]}\end{array}$ & $\begin{array}{l}-0.16 \\
{[.121]}\end{array}$ & $\begin{array}{l}-0.15 \\
{[.101]}\end{array}$ & $\begin{array}{l}-0.11 \\
{[.328]}\end{array}$ & $\begin{array}{c}-0.14 \\
{[.164]}\end{array}$ & $\begin{array}{c}-0.05 \\
{[.537]}\end{array}$ & $\begin{array}{l}-0.32^{b} \\
{[.033]}\end{array}$ & $\begin{array}{c}0.10 \\
{[.107]}\end{array}$ & $\begin{array}{l}-0.01 \\
{[.922]}\end{array}$ \\
\hline Town size 4 & $\begin{array}{c}0.24^{b} \\
{[.020]}\end{array}$ & $\begin{array}{c}0.03 \\
{[.783]}\end{array}$ & $\begin{array}{c}0.06 \\
{[.373]}\end{array}$ & $\begin{array}{c}0.19^{b} \\
{[.041]}\end{array}$ & $\begin{array}{c}0.23^{b} \\
{[.010]}\end{array}$ & $\begin{array}{l}0.23^{b} \\
{[.022]}\end{array}$ & $\begin{array}{c}0.28^{\mathrm{a}} \\
{[.003]}\end{array}$ & $\begin{array}{l}0.23^{b} \\
{[.010]}\end{array}$ & $\begin{array}{c}0.17 \\
{[.223]}\end{array}$ & $\begin{array}{c}0.47^{\mathrm{a}} \\
{[.000]}\end{array}$ & $\begin{array}{c}0.29^{b} \\
{[.010]}\end{array}$ \\
\hline Town size 5 & $\begin{array}{c}-0.08 \\
{[.342]}\end{array}$ & $\begin{array}{l}-0.29^{\mathrm{a}} \\
{[.001]}\end{array}$ & $\begin{array}{l}-0.37^{\mathrm{a}} \\
{[.000]}\end{array}$ & $\begin{array}{l}-0.22^{b} \\
{[.013]}\end{array}$ & $\begin{array}{l}-0.30^{\mathrm{a}} \\
{[.000]}\end{array}$ & $\begin{array}{l}-0.16{ }^{c} \\
{[.099]}\end{array}$ & $\begin{array}{c}-0.04 \\
{[.627]}\end{array}$ & $\begin{array}{c}0.01 \\
{[.891]}\end{array}$ & $\begin{array}{l}-0.47^{\mathrm{a}} \\
{[.002]}\end{array}$ & $\begin{array}{c}-0.07 \\
{[.139]}\end{array}$ & $\begin{array}{c}-0.11 \\
{[.250]}\end{array}$ \\
\hline Peasant & $\begin{array}{c}\mathbf{0 . 7 3}^{\mathrm{b}} \\
{[.017]}\end{array}$ & $\begin{array}{c}0.40 \\
{[.140]}\end{array}$ & $\begin{array}{c}-0.14 \\
{[.565]}\end{array}$ & $\begin{array}{c}0.48^{\mathrm{c}} \\
{[.075]}\end{array}$ & $\begin{array}{c}0.08 \\
{[.770]}\end{array}$ & $\begin{array}{c}0.58^{\mathrm{c}} \\
{[.061]}\end{array}$ & $\begin{array}{c}1.03^{\mathrm{a}} \\
{[.000]}\end{array}$ & $\begin{array}{l}0.64^{b} \\
{[.011]}\end{array}$ & $\begin{array}{l}0.74^{\mathrm{b}} \\
{[.039]}\end{array}$ & $\begin{array}{c}0.70^{\mathrm{a}} \\
{[.002]}\end{array}$ & $\begin{array}{c}0.66^{\mathbf{b}} \\
{[.035]}\end{array}$ \\
\hline Worker & $\begin{array}{c}0.18 \\
{[.473]}\end{array}$ & $\begin{array}{c}-0.07 \\
{[.758]}\end{array}$ & $\begin{array}{c}-0.46^{\mathrm{a}} \\
{[.009]}\end{array}$ & $\begin{array}{c}0.10 \\
{[.656]}\end{array}$ & $\begin{array}{c}-0.33 \\
{[.143]}\end{array}$ & $\begin{array}{c}0.26 \\
{[.276]}\end{array}$ & $\begin{array}{c}0.12 \\
{[.558]}\end{array}$ & $\begin{array}{c}0.21 \\
{[.281]}\end{array}$ & $\begin{array}{c}0.26 \\
{[.323]}\end{array}$ & $\begin{array}{l}-0.61^{\mathrm{a}} \\
{[.003]}\end{array}$ & $\begin{array}{c}0.12 \\
{[.659]}\end{array}$ \\
\hline Clerk & $\begin{array}{c}0.32 \\
{[.213]}\end{array}$ & $\begin{array}{c}0.08 \\
{[.719]}\end{array}$ & $\begin{array}{c}-0.22 \\
{[.219]}\end{array}$ & $\begin{array}{c}0.25 \\
{[.254]}\end{array}$ & $\begin{array}{c}-0.04 \\
{[.854]}\end{array}$ & $\begin{array}{l}0.50^{b} \\
{[.036]}\end{array}$ & $\begin{array}{c}0.17 \\
{[.421]}\end{array}$ & $\begin{array}{c}0.29 \\
{[.143]}\end{array}$ & $\begin{array}{c}0.52^{\mathrm{c}} \\
{[.051]}\end{array}$ & $\begin{array}{l}-0.51^{b} \\
{[.013]}\end{array}$ & $\begin{array}{c}0.38 \\
{[.158]}\end{array}$ \\
\hline Specialist & $\begin{array}{c}0.44^{\mathrm{c}} \\
{[.089]}\end{array}$ & $\begin{array}{c}0.10 \\
{[.648]}\end{array}$ & $\begin{array}{c}-0.24 \\
{[.174]}\end{array}$ & $\begin{array}{c}0.20 \\
{[.369]}\end{array}$ & $\begin{array}{c}-0.08 \\
{[.724]}\end{array}$ & $\begin{array}{c}0.37 \\
{[.137]}\end{array}$ & $\begin{array}{c}0.39^{\mathrm{c}} \\
{[.070]}\end{array}$ & $\begin{array}{c}0.34^{\mathrm{c}} \\
{[.096]}\end{array}$ & $\begin{array}{c}0.61^{b} \\
{[.026]}\end{array}$ & $\begin{array}{l}-0.45^{b} \\
{[.034]}\end{array}$ & $\begin{array}{c}0.39 \\
{[.146]}\end{array}$ \\
\hline Businessman & $\begin{array}{c}0.51^{\mathrm{c}} \\
{[.070]}\end{array}$ & $\begin{array}{c}0.23 \\
{[.354]}\end{array}$ & $\begin{array}{c}-0.07 \\
{[.711]}\end{array}$ & $\begin{array}{c}0.33 \\
{[.172]}\end{array}$ & $\begin{array}{c}0.01 \\
{[.960]}\end{array}$ & $\begin{array}{c}\mathbf{0 . 5 6}^{\mathbf{b}} \\
{[.037]}\end{array}$ & $\begin{array}{c}0.51^{b} \\
{[.033]}\end{array}$ & $\begin{array}{c}0.63^{\mathrm{a}} \\
{[.005]}\end{array}$ & $\begin{array}{c}0.70^{b} \\
{[.018]}\end{array}$ & $\begin{array}{c}0.00 \\
{[1.00]}\end{array}$ & $\begin{array}{c}0.77^{\mathrm{a}} \\
{[.010]}\end{array}$ \\
\hline Retired & $\begin{array}{c}0.48^{\mathrm{c}} \\
{[.063]}\end{array}$ & $\begin{array}{c}0.04 \\
{[.845]}\end{array}$ & $\begin{array}{c}-0.03 \\
{[.855]}\end{array}$ & $\begin{array}{c}0.23 \\
{[.311]}\end{array}$ & $\begin{array}{c}-0.12 \\
{[.591]}\end{array}$ & $\begin{array}{c}0.53^{b} \\
{[.038]}\end{array}$ & $\begin{array}{c}0.45^{b} \\
{[.046]}\end{array}$ & $\begin{array}{c}0.45^{\mathrm{b}} \\
{[.030]}\end{array}$ & $\begin{array}{c}0.48^{\mathrm{c}} \\
{[.084]}\end{array}$ & $\begin{array}{l}-0.43^{b} \\
{[.043]}\end{array}$ & $\begin{array}{c}0.40 \\
{[.145]}\end{array}$ \\
\hline Student & $\begin{array}{c}0.37 \\
{[.162]}\end{array}$ & $\begin{array}{c}0.15 \\
{[.537]}\end{array}$ & $\begin{array}{c}0.07 \\
{[.735]}\end{array}$ & $\begin{array}{c}0.18 \\
{[.440]}\end{array}$ & $\begin{array}{c}-0.12 \\
{[.628]}\end{array}$ & $\begin{array}{c}0.31 \\
{[.219]}\end{array}$ & $\begin{array}{c}0.11 \\
{[.645]}\end{array}$ & $\begin{array}{c}0.32 \\
{[.152]}\end{array}$ & $\begin{array}{c}0.33 \\
{[.247]}\end{array}$ & $\begin{array}{c}0.29 \\
{[.205]}\end{array}$ & $\begin{array}{c}0.45 \\
{[.106]}\end{array}$ \\
\hline Homemaker & $\begin{array}{c}0.35 \\
{[.193]}\end{array}$ & $\begin{array}{c}0.22 \\
{[.341]}\end{array}$ & $\begin{array}{c}-0.22 \\
{[.256]}\end{array}$ & $\begin{array}{c}0.30 \\
{[.187]}\end{array}$ & $\begin{array}{c}-0.06 \\
{[.805]}\end{array}$ & $\begin{array}{c}0.42 \\
{[.115]}\end{array}$ & $\begin{array}{c}0.20 \\
{[.378]}\end{array}$ & $\begin{array}{c}0.29 \\
{[.187]}\end{array}$ & $\begin{array}{c}0.30 \\
{[.316]}\end{array}$ & $\begin{array}{c}-0.26 \\
{[.235]}\end{array}$ & $\begin{array}{c}\mathbf{0 . 6 1}^{\mathbf{b}} \\
{[.027]}\end{array}$ \\
\hline Unemployed & $\begin{array}{c}0.32 \\
{[.211]}\end{array}$ & $\begin{array}{c}-0.02 \\
{[.939]}\end{array}$ & $\begin{array}{c}-0.09 \\
{[.615]}\end{array}$ & $\begin{array}{c}0.13 \\
{[.562]}\end{array}$ & $\begin{array}{c}-0.20 \\
{[.377]}\end{array}$ & $\begin{array}{l}0.44^{\mathrm{c}} \\
{[.069]}\end{array}$ & $\begin{array}{c}0.32 \\
{[.132]}\end{array}$ & $\begin{array}{l}0.42^{\mathrm{b}} \\
{[.035]}\end{array}$ & $\begin{array}{c}0.55^{b} \\
{[.039]}\end{array}$ & $\begin{array}{c}-0.23 \\
{[.271]}\end{array}$ & $\begin{array}{c}0.40 \\
{[.138]}\end{array}$ \\
\hline Age & $\begin{array}{l}-0.01 \\
{[.001}\end{array}$ & $\begin{array}{l}-0.01 \\
{[.005}\end{array}$ & $\begin{array}{l}-0.02^{\mathrm{a}} \\
{[.000]}\end{array}$ & $\begin{array}{l}-0.01^{b} \\
{[.034]}\end{array}$ & $\begin{array}{l}-0.01 \\
{[.022]}\end{array}$ & $\begin{array}{l}-0.01^{c} \\
{[.058]}\end{array}$ & $\begin{array}{l}-0.01^{b} \\
{[.015]}\end{array}$ & $\begin{array}{l}-0.011^{\mathrm{a}} \\
{[.001]}\end{array}$ & $\begin{array}{l}-0.01^{\mathrm{a}} \\
{[.001]}\end{array}$ & $\begin{array}{c}0.00 \\
{[.213]}\end{array}$ & $\begin{array}{l}-0.01^{b} \\
{[.041]}\end{array}$ \\
\hline Gender & $\begin{array}{l}-0.05 \\
{[.501]}\end{array}$ & $\begin{array}{l}-0.13^{\mathrm{c}} \\
{[.085]}\end{array}$ & $\begin{array}{l}-0.11^{b} \\
{[.018]}\end{array}$ & $\begin{array}{l}-0.06 \\
{[.401]}\end{array}$ & $\begin{array}{l}-0.09 \\
{[.171]}\end{array}$ & $\begin{array}{c}-0.08 \\
{[.388]}\end{array}$ & $\begin{array}{l}-0.05 \\
{[.500]}\end{array}$ & $\begin{array}{l}-0.02 \\
{[.744]}\end{array}$ & $\begin{array}{l}-0.05 \\
{[.500]}\end{array}$ & $\begin{array}{l}-0.05 \\
{[.353]}\end{array}$ & $\begin{array}{l}-0.04 \\
{[.636]}\end{array}$ \\
\hline $\begin{array}{l}\text { Correction } \\
\text { variable }\end{array}$ & $\begin{array}{l}-0.36 \\
{[.332]}\end{array}$ & $\begin{array}{l}-0.69^{b} \\
{[.045]}\end{array}$ & $\begin{array}{l}-0.27 \\
{[.187]}\end{array}$ & $\begin{array}{l}-0.15 \\
{[.596]}\end{array}$ & $\begin{array}{l}-0.41 \\
{[.160]}\end{array}$ & $\begin{array}{c}0.00 \\
{[.991]}\end{array}$ & $\begin{array}{c}0.05 \\
{[.887]}\end{array}$ & $\begin{array}{l}-0.25 \\
{[.459]}\end{array}$ & $\begin{array}{l}-1.18^{\mathrm{a}} \\
{[.004]}\end{array}$ & $\begin{array}{l}-0.31^{b} \\
{[.019]}\end{array}$ & $\begin{array}{l}-0.28 \\
{[.388]}\end{array}$ \\
\hline $\begin{array}{l}\text { Correlation } \\
\text { coefficient }\end{array}$ & $\begin{array}{l}-0.89^{\mathrm{a}} \\
{[.000]}\end{array}$ & $\begin{array}{l}-0.94^{\mathrm{a}} \\
{[.000]}\end{array}$ & $\begin{array}{l}-0.79^{\mathrm{a}} \\
{[.000]}\end{array}$ & $\begin{array}{l}-0.72^{\mathrm{a}} \\
{[.000]}\end{array}$ & $\begin{array}{c}-0.98 a^{a} \\
{[.000]}\end{array}$ & $\begin{array}{l}-0.46^{\mathrm{a}} \\
{[.003]}\end{array}$ & $\begin{array}{l}-0.97^{\mathrm{a}} \\
{[.000]}\end{array}$ & $\begin{array}{l}-0.67^{\mathrm{a}} \\
{[.000]}\end{array}$ & $\begin{array}{l}-0.67^{\mathrm{a}} \\
{[.000]}\end{array}$ & $\begin{array}{l}-0.96^{\mathrm{a}} \\
{[.000]}\end{array}$ & $\begin{array}{l}-0.53^{\mathrm{a}} \\
{[.000]}\end{array}$ \\
\hline Number of obs. & 1217 & 1421 & 1365 & 1395 & 1488 & 1170 & 1139 & 1162 & 900 & 1125 & 735 \\
\hline
\end{tabular}

${ }^{10}$ No fight is perceived unwillingness of the government to fight corruption 
Table 9. Joint Estimation, Corruption perception equation (equation 4b)

\begin{tabular}{|c|c|c|c|c|c|c|c|c|c|c|c|}
\hline Parameter & $\begin{array}{c}\text { Central } \\
\text { Govt. }\end{array}$ & $\begin{array}{l}\text { Local } \\
\text { Govt. }\end{array}$ & $\begin{array}{l}\text { Juridic. } \\
\text { Instit. }\end{array}$ & $\begin{array}{c}\text { Inspec- } \\
\text { tions }\end{array}$ & Police & Army & $\begin{array}{l}\text { Educat. } \\
\text { Establ. }\end{array}$ & $\begin{array}{l}\text { Medic. } \\
\text { Establ. }\end{array}$ & $\begin{array}{c}\text { State } \\
\text { TV }\end{array}$ & $\begin{array}{l}\text { Privat. } \\
\text { Author. }\end{array}$ & Banks \\
\hline Constant & $\begin{array}{c}2.02^{\mathrm{a}} \\
{[.000]}\end{array}$ & $\begin{array}{l}1.79^{\mathrm{a}} \\
{[.000]}\end{array}$ & $\begin{array}{l}1.73^{\mathrm{a}} \\
{[.000]}\end{array}$ & $\begin{array}{l}2.46^{\mathrm{a}} \\
{[.000]}\end{array}$ & $\begin{array}{c}1.86^{\mathrm{a}} \\
{[.000]}\end{array}$ & $\begin{array}{l}1.15^{\mathrm{a}} \\
{[.004]}\end{array}$ & $\begin{array}{c}1.72^{\mathrm{a}} \\
{[.000]}\end{array}$ & $\begin{array}{l}2.27^{\mathrm{a}} \\
{[.000]}\end{array}$ & $\begin{array}{c}1.43^{\mathrm{a}} \\
{[.006]}\end{array}$ & $\begin{array}{l}2.14^{\mathrm{a}} \\
{[.000]}\end{array}$ & $\begin{array}{l}1.13^{\mathrm{b}} \\
{[.013]}\end{array}$ \\
\hline $\begin{array}{l}\text { Frequency of } \\
\text { Visits }=1\end{array}$ & $\begin{array}{c}0.00 \\
{[.982]}\end{array}$ & $\begin{array}{c}0.07 \\
{[.195]}\end{array}$ & $\begin{array}{c}0.18^{\mathrm{a}} \\
{[.000]}\end{array}$ & $\begin{array}{l}0.12^{\mathrm{c}} \\
{[.093]}\end{array}$ & $\begin{array}{c}0.10^{c} \\
{[.050]}\end{array}$ & $\begin{array}{c}0.07 \\
{[.643]}\end{array}$ & & & $\begin{array}{l}-0.05 \\
{[.834]}\end{array}$ & & \\
\hline $\begin{array}{l}\text { Frequency of } \\
\text { Visits }=2\end{array}$ & $\begin{array}{l}- \\
-\end{array}$ & $\begin{array}{l}0^{0.21}{ }^{b} \\
{[.013]}\end{array}$ & $\begin{array}{l}- \\
-\end{array}$ & - & $\begin{array}{l}- \\
-\end{array}$ & - & $\begin{array}{l}-0.02 \\
{[.772]}\end{array}$ & $\begin{array}{l}-0.09 \\
{[.211]}\end{array}$ & - & $\begin{array}{c}0.31^{\mathrm{c}} \\
{[.081]}\end{array}$ & $\begin{array}{c}-0.22 \\
{[.341]}\end{array}$ \\
\hline $\begin{array}{l}\text { Frequency of } \\
\text { Visits }=3\end{array}$ & - & - & - & - & - & $\begin{array}{l}- \\
-\end{array}$ & - & & - & - & $\begin{array}{c}-0.24 \\
{[.378]}\end{array}$ \\
\hline Press $=1$ & $\begin{array}{l}-0.15 \\
{[.430]}\end{array}$ & $\begin{array}{l}-0.59^{b} \\
{[.043]}\end{array}$ & $\begin{array}{l}-0.53^{\mathrm{a}} \\
{[.000]}\end{array}$ & $\begin{array}{c}-0.11 \\
{[.593]}\end{array}$ & $\begin{array}{l}-0.10 \\
{[.606]}\end{array}$ & $\begin{array}{l}-0.60^{b} \\
{[.013]}\end{array}$ & $\begin{array}{c}0.05 \\
{[.706]}\end{array}$ & $\begin{array}{l}-0.81^{\mathrm{a}} \\
{[.002]}\end{array}$ & $\begin{array}{c}-0.33 \\
{[.100]}\end{array}$ & $\begin{array}{l}-0.37^{b} \\
{[.011]}\end{array}$ & $\begin{array}{l}-0.56^{b} \\
{[.014]}\end{array}$ \\
\hline Press $=2$ & & & & & & & & & & & \\
\hline Press $=3$ & $\begin{array}{l}-0.16 \\
{[.445]}\end{array}$ & $\begin{array}{l}-0.54^{\mathrm{c}} \\
{[.075]}\end{array}$ & & $\begin{array}{c}-0.03 \\
{[.884]}\end{array}$ & & & $\begin{array}{c}0.14 \\
{[.345]}\end{array}$ & & $\begin{array}{l}-0.31 \\
{[.205]}\end{array}$ & & \\
\hline Press $=4$ & & & & & & & & & & & \\
\hline Press $=5$ & $\begin{array}{l}-0.11 \\
{[.614]}\end{array}$ & & & $\begin{array}{c}0.02 \\
{[.921]}\end{array}$ & $\begin{array}{c}0.08 \\
{[.713]}\end{array}$ & & & & $\begin{array}{c}0.13 \\
{[.631]}\end{array}$ & & \\
\hline $\mathrm{TV}=1$ & & & & & & & & & & & \\
\hline$\Gamma \mathrm{V}=2$ & $\begin{array}{c}0.07 \\
{[.783]}\end{array}$ & $\begin{array}{c}0.11 \\
{[.700]} \\
\end{array}$ & & & & $\begin{array}{c}0.20 \\
{[.440]}\end{array}$ & & $\begin{array}{c}0.06 \\
{[.806]}\end{array}$ & $\begin{array}{l}-0.30 \\
{[.209]}\end{array}$ & & $\begin{array}{l}-0.07 \\
{[.815]}\end{array}$ \\
\hline $\mathrm{TV}=3$ & & & & & & & & & & & \\
\hline$\Gamma \mathrm{V}=4$ & $\begin{array}{l}-0.50^{\mathrm{b}} \\
{[.022]}\end{array}$ & $\begin{array}{l}-0.04 \\
{[.877]}\end{array}$ & $\begin{array}{l}-0.15 \\
{[.230]}\end{array}$ & $\begin{array}{l}-0.38^{\mathrm{c}} \\
{[.073]}\end{array}$ & $\begin{array}{c}0.01 \\
{[.940]}\end{array}$ & $\begin{array}{c}0.12 \\
{[.605]}\end{array}$ & $\begin{array}{c}0.00 \\
{[.997]}\end{array}$ & & $\begin{array}{c}0.04 \\
{[.857]}\end{array}$ & $\begin{array}{l}-0.42^{\mathrm{a}} \\
{[.000]}\end{array}$ & $\begin{array}{l}-0.35 \\
{[.185]}\end{array}$ \\
\hline $\mathrm{TV}=5$ & & & & & & & & & & & \\
\hline Radio $=1$ & $\begin{array}{c}0.44^{\mathrm{c}} \\
{[.061]}\end{array}$ & $\begin{array}{c}0.15 \\
{[.607]}\end{array}$ & $\begin{array}{c}0.06 \\
{[.752]}\end{array}$ & $\begin{array}{l}-0.14 \\
{[.698]}\end{array}$ & $\begin{array}{l}-0.10 \\
{[.693]}\end{array}$ & & $\begin{array}{c}0.01 \\
{[.971]}\end{array}$ & $\begin{array}{c}0.43 \\
{[.121]}\end{array}$ & $\begin{array}{l}-0.25 \\
{[.361]}\end{array}$ & $\begin{array}{l}0.48^{\mathrm{a}} \\
{[.007]}\end{array}$ & $\begin{array}{c}0.16 \\
{[.616]}\end{array}$ \\
\hline Radio $=2$ & $\begin{array}{c}0.06 \\
{[.827]}\end{array}$ & & & & & & $\begin{array}{c}0.05 \\
{[.752]}\end{array}$ & & & $\begin{array}{l}0.41^{\mathrm{b}} \\
{[.026]}\end{array}$ & $\begin{array}{c}0.04 \\
{[.905]}\end{array}$ \\
\hline Radio $=3$ & $\begin{array}{c}0.49^{c} \\
{[.059]}\end{array}$ & $\begin{array}{l}-0.06 \\
{[.848]}\end{array}$ & $\begin{array}{c}0.01 \\
{[.940]}\end{array}$ & $\begin{array}{l}-0.06 \\
{[.890]}\end{array}$ & $\begin{array}{l}-0.26 \\
{[.318]}\end{array}$ & $\begin{array}{c}0.09 \\
{[.761]}\end{array}$ & $\begin{array}{c}0.11 \\
{[.501]}\end{array}$ & $\begin{array}{l}0^{0.68}{ }^{\mathrm{b}} \\
{[.030]}\end{array}$ & $\begin{array}{l}-0.47 \\
{[.135]}\end{array}$ & $\begin{array}{l}0^{0.44^{b}} \\
{[.017]}\end{array}$ & $\begin{array}{c}0.25 \\
{[.488]}\end{array}$ \\
\hline Radio $=4$ & $\begin{array}{c}0.42^{\mathrm{c}} \\
{[.094]}\end{array}$ & $\begin{array}{c}0.08 \\
{[.778]}\end{array}$ & $\begin{array}{c}-0.04 \\
{[.835]}\end{array}$ & $\begin{array}{c}-0.03 \\
{[.936]}\end{array}$ & $\begin{array}{c}-0.22 \\
{[.388]}\end{array}$ & $\begin{array}{c}-0.11 \\
{[.694]}\end{array}$ & $\begin{array}{c}0.02 \\
{[.899]}\end{array}$ & $\begin{array}{c}0.25 \\
{[.400]}\end{array}$ & $\begin{array}{c}-0.31 \\
{[.302]}\end{array}$ & $\begin{array}{c}0^{0.39^{b}} \\
{[.028]}\end{array}$ & $\begin{array}{c}0.11 \\
{[.747]}\end{array}$ \\
\hline Radio $=5$ & $\begin{array}{c}0.16 \\
{[.538]}\end{array}$ & $\begin{array}{c}0.24 \\
{[.442]}\end{array}$ & $\begin{array}{c}-0.11 \\
{[.579]}\end{array}$ & $\begin{array}{c}-0.18 \\
{[.645]}\end{array}$ & $\begin{array}{c}-0.07 \\
{[.787]}\end{array}$ & $\begin{array}{c}-0.26 \\
{[.420]}\end{array}$ & $\begin{array}{c}0.02 \\
{[.930]}\end{array}$ & $\begin{array}{c}0.42 \\
{[.190]}\end{array}$ & $\begin{array}{c}-0.34 \\
{[.297]}\end{array}$ & $\begin{array}{c}0.25 \\
{[.175]}\end{array}$ & $\begin{array}{c}0.03 \\
{[.940]}\end{array}$ \\
\hline Friends & $\begin{array}{l}-0.14^{\mathrm{a}} \\
{[.004]}\end{array}$ & $\begin{array}{l}-0.15^{\mathrm{a}} \\
{[.002]}\end{array}$ & $\begin{array}{l}-0.09^{\mathrm{a}} \\
{[.000]}\end{array}$ & $\begin{array}{l}-0.17^{\mathrm{a}} \\
{[.005]}\end{array}$ & $\begin{array}{l}-0.09^{\mathrm{c}} \\
{[.060]}\end{array}$ & $\begin{array}{l}-0.07 \\
{[.286]}\end{array}$ & $\begin{array}{l}-0.08^{\mathrm{c}} \\
{[.050]}\end{array}$ & $\begin{array}{l}-0.08 \\
{[.166]}\end{array}$ & $\begin{array}{l}-0.21^{a} \\
{[.004]}\end{array}$ & $\begin{array}{l}-0.06^{\mathrm{a}} \\
{[.000]}\end{array}$ & $\begin{array}{l}-0.14^{b} \\
{[.045]}\end{array}$ \\
\hline Strangers & $\begin{array}{c}0.06 \\
{[.300]}\end{array}$ & $\begin{array}{c}0.01 \\
{[.907]}\end{array}$ & $\begin{array}{c}0.12^{\mathrm{a}} \\
{[.000]}\end{array}$ & $\begin{array}{c}0.00 \\
{[.960]}\end{array}$ & $\begin{array}{c}0.03 \\
{[.528]}\end{array}$ & $\begin{array}{c}0.04 \\
{[.622]}\end{array}$ & $\begin{array}{c}\mathbf{0 . 0 8}^{\mathrm{c}} \\
{[.094]}\end{array}$ & $\begin{array}{c}0.11 \\
{[.125]}\end{array}$ & $\begin{array}{c}0.06 \\
{[.460]}\end{array}$ & $\begin{array}{l}-0.11^{a} \\
{[.000]}\end{array}$ & $\begin{array}{c}0.07 \\
{[.390]}\end{array}$ \\
\hline Experience & $\begin{array}{c}0.14^{\mathrm{a}} \\
{[.008]}\end{array}$ & $\begin{array}{c}0.20^{\mathrm{a}} \\
{[.000]}\end{array}$ & $\begin{array}{c}0.09^{\mathrm{a}} \\
{[.000]}\end{array}$ & $\begin{array}{c}0.23^{\mathrm{a}} \\
{[.000]}\end{array}$ & $\begin{array}{c}0.16^{\mathrm{a}} \\
{[.003]}\end{array}$ & $\begin{array}{c}0.29^{\mathrm{a}} \\
{[.000]}\end{array}$ & $\begin{array}{c}0.23^{\mathrm{a}} \\
{[.000]}\end{array}$ & $\begin{array}{l}0.24^{\mathrm{a}} \\
{[.000]}\end{array}$ & $\begin{array}{c}0.25^{\mathrm{a}} \\
{[.001]}\end{array}$ & $\begin{array}{c}0.15^{\mathrm{a}} \\
{[.000]}\end{array}$ & $\begin{array}{l}0.22^{\mathrm{a}} \\
{[.003]}\end{array}$ \\
\hline
\end{tabular}


Table 9. Continued

\begin{tabular}{|c|c|c|c|c|c|c|c|c|c|c|c|}
\hline \begin{tabular}{|l} 
Institutic \\
Parameter
\end{tabular} & $\begin{array}{c}\text { Central } \\
\text { Govt. }\end{array}$ & $\begin{array}{l}\text { Local } \\
\text { Govt. }\end{array}$ & $\begin{array}{l}\text { Juridic. } \\
\text { Instit. }\end{array}$ & $\begin{array}{c}\text { Inspec- } \\
\text { tions }\end{array}$ & Police & Army & $\begin{array}{l}\text { Educat. } \\
\text { Establ. }\end{array}$ & $\begin{array}{l}\text { Medic. } \\
\text { Establ. }\end{array}$ & $\begin{array}{c}\text { State } \\
\text { TV }\end{array}$ & $\begin{array}{l}\text { Privat. } \\
\text { Author. }\end{array}$ & Banks \\
\hline Town size 2 & $\begin{array}{c}0.08 \\
{[.504]}\end{array}$ & $\begin{array}{c}0.22^{\mathrm{c}} \\
{[.054]}\end{array}$ & $\begin{array}{c}0.18^{b} \\
{[.043]}\end{array}$ & $\begin{array}{c}0.06 \\
{[.594]} \\
\end{array}$ & $\begin{array}{c}0.12 \\
{[.273]}\end{array}$ & $\begin{array}{c}0.20^{\mathrm{c}} \\
{[.081]}\end{array}$ & $\begin{array}{c}0.22^{b} \\
{[.048]}\end{array}$ & $\begin{array}{c}0.20^{\mathrm{c}} \\
{[.091]} \\
\end{array}$ & $\begin{array}{c}0.65^{\mathrm{a}} \\
{[.000]}\end{array}$ & $\begin{array}{c}0.10 \\
{[.133]}\end{array}$ & $\begin{array}{c}0.11 \\
{[.389]}\end{array}$ \\
\hline Town size 3 & $\begin{array}{c}0.57^{\mathrm{a}} \\
{[.000]}\end{array}$ & $\begin{array}{c}0.72^{\mathrm{a}} \\
{[.000]}\end{array}$ & $\begin{array}{l}0.52^{\mathrm{a}} \\
{[.000]}\end{array}$ & $\begin{array}{c}0.54^{\mathrm{a}} \\
{[.000]}\end{array}$ & $\begin{array}{c}0.24^{b} \\
{[.016]}\end{array}$ & $\begin{array}{c}0.32^{\mathrm{a}} \\
{[.003]}\end{array}$ & $\begin{array}{c}0.41^{\mathrm{a}} \\
{[.000]}\end{array}$ & $\begin{array}{c}0.32^{\mathrm{a}} \\
{[.003]} \\
\end{array}$ & $\begin{array}{c}0.80^{\mathrm{a}} \\
{[.000]}\end{array}$ & $\begin{array}{c}0^{1.13}{ }^{b} \\
{[.020]}\end{array}$ & $\begin{array}{l}0.41^{\mathrm{a}} \\
{[.001]}\end{array}$ \\
\hline Town size 4 & $\begin{array}{c}-0.06 \\
{[.546]}\end{array}$ & $\begin{array}{c}0.32^{\mathrm{a}} \\
{[.001]}\end{array}$ & $\begin{array}{c}-0.03 \\
{[.691]}\end{array}$ & $\begin{array}{c}-0.12 \\
{[.235]}\end{array}$ & $\begin{array}{l}-0.22^{\mathrm{b}} \\
{[.020]}\end{array}$ & $\begin{array}{c}-0.01 \\
{[.912]}\end{array}$ & $\begin{array}{l}-0.19^{b} \\
{[.036]}\end{array}$ & $\begin{array}{c}-0.11 \\
{[.297]} \\
\end{array}$ & $\begin{array}{l}0.32^{\mathrm{a}} \\
{[.006]}\end{array}$ & $\begin{array}{l}-0.28^{\mathrm{a}} \\
{[.000]}\end{array}$ & $\begin{array}{l}-0.25^{b} \\
{[.025]}\end{array}$ \\
\hline Town size 5 & $\begin{array}{c}0.38^{\mathrm{a}} \\
{[.000]}\end{array}$ & $\begin{array}{c}0.62^{\mathrm{a}} \\
{[.000]}\end{array}$ & $\begin{array}{c}0.63^{\mathrm{a}} \\
{[.000]}\end{array}$ & $\begin{array}{l}0.61^{\mathrm{a}} \\
{[.000]}\end{array}$ & $\begin{array}{c}0.44^{\mathrm{a}} \\
{[.000]}\end{array}$ & $\begin{array}{c}0.28^{\mathrm{a}} \\
{[.004]}\end{array}$ & $\begin{array}{c}0.20^{b} \\
{[.016]}\end{array}$ & $\begin{array}{c}0.05 \\
{[.617]}\end{array}$ & $\begin{array}{c}1^{1.08}{ }^{a} \\
{[.000]}\end{array}$ & $\begin{array}{c}0.16^{\mathrm{a}} \\
{[.001]}\end{array}$ & $\begin{array}{c}0.28^{\mathrm{a}} \\
{[.007]}\end{array}$ \\
\hline Peasant & $\begin{array}{c}0.03 \\
{[.928]}\end{array}$ & $\begin{array}{c}0.23 \\
{[.436]}\end{array}$ & $\begin{array}{c}0.45^{b} \\
{[.043]}\end{array}$ & $\begin{array}{c}0.24 \\
{[.425]}\end{array}$ & $\begin{array}{c}0.26 \\
{[.338]}\end{array}$ & $\begin{array}{c}0.08 \\
{[.785]}\end{array}$ & $\begin{array}{c}-0.46 \\
{[.106]}\end{array}$ & $\begin{array}{c}-0.43 \\
{[.118]}\end{array}$ & $\begin{array}{c}-0.07 \\
{[.863]}\end{array}$ & $\begin{array}{c}-0.08 \\
{[.676]}\end{array}$ & $\begin{array}{c}-0.22 \\
{[.513]}\end{array}$ \\
\hline Worker & $\begin{array}{c}0.22 \\
{[.441]}\end{array}$ & $\begin{array}{c}0.50^{b} \\
{[.046]}\end{array}$ & $\begin{array}{l}0.46^{\mathrm{a}} \\
{[.001]}\end{array}$ & $\begin{array}{c}0.31 \\
{[.191]}\end{array}$ & $\begin{array}{c}0.60^{\mathrm{a}} \\
{[.009]}\end{array}$ & $\begin{array}{c}0.15 \\
{[.546]}\end{array}$ & $\begin{array}{c}0.17 \\
{[.447]}\end{array}$ & $\begin{array}{c}0.10 \\
{[.637]}\end{array}$ & $\begin{array}{l}-0.16 \\
{[.619]}\end{array}$ & $\begin{array}{c}0.76^{\mathrm{a}} \\
{[.000]}\end{array}$ & $\begin{array}{c}0.16 \\
{[.579]}\end{array}$ \\
\hline Clerk & $\begin{array}{c}-0.10 \\
{[.730]}\end{array}$ & $\begin{array}{c}0.32 \\
{[.220]}\end{array}$ & $\begin{array}{c}0.13 \\
{[.385]}\end{array}$ & $\begin{array}{c}0.07 \\
{[.782]}\end{array}$ & $\begin{array}{c}0.27 \\
{[.238]}\end{array}$ & $\begin{array}{c}-0.05 \\
{[.850]}\end{array}$ & $\begin{array}{c}0.21 \\
{[.368]}\end{array}$ & $\begin{array}{c}0.07 \\
{[.765]}\end{array}$ & $\begin{array}{c}-0.22 \\
{[.514]}\end{array}$ & $\begin{array}{c}0.70^{\mathrm{a}} \\
{[.000]}\end{array}$ & $\begin{array}{c}0.04 \\
{[.901]}\end{array}$ \\
\hline Specialist & $\begin{array}{c}-0.25 \\
{[.390]}\end{array}$ & $\begin{array}{c}0.27 \\
{[.295]}\end{array}$ & $\begin{array}{c}0.12 \\
{[.366]}\end{array}$ & $\begin{array}{c}0.18 \\
{[.467]}\end{array}$ & $\begin{array}{c}0.27 \\
{[.242]}\end{array}$ & $\begin{array}{c}0.07 \\
{[.802]}\end{array}$ & $\begin{array}{c}-0.16 \\
{[.502]}\end{array}$ & $\begin{array}{c}-0.05 \\
{[.819]}\end{array}$ & $\begin{array}{c}-0.42 \\
{[.219]}\end{array}$ & $\begin{array}{c}0.69^{\mathrm{a}} \\
{[.000]}\end{array}$ & $\begin{array}{c}-0.08 \\
{[.795]}\end{array}$ \\
\hline Businesman & $\begin{array}{c}0.12 \\
{[.702]}\end{array}$ & $\begin{array}{c}0.49^{c} \\
{[.098]}\end{array}$ & $\begin{array}{l}0.34^{b} \\
{[.029]}\end{array}$ & $\begin{array}{c}0.46 \\
{[.113]}\end{array}$ & $\begin{array}{c}0.33 \\
{[.203]}\end{array}$ & $\begin{array}{c}0.00 \\
{[.994]}\end{array}$ & $\begin{array}{c}-0.06 \\
{[.803]}\end{array}$ & $\begin{array}{c}-0.29 \\
{[.288]}\end{array}$ & $\begin{array}{c}-0.20 \\
{[.596]}\end{array}$ & $\begin{array}{c}0.39^{c} \\
{[.052]}\end{array}$ & $\begin{array}{c}0.00 \\
{[.998]}\end{array}$ \\
\hline Retired & $\begin{array}{c}-0.18 \\
{[.545]}\end{array}$ & $\begin{array}{c}0.44 \\
{[.106]}\end{array}$ & $\begin{array}{c}-0.02 \\
{[.921]}\end{array}$ & $\begin{array}{c}0.19 \\
{[.443]}\end{array}$ & $\begin{array}{c}0.40 \\
{[.100]}\end{array}$ & $\begin{array}{c}0.03 \\
{[.901]}\end{array}$ & $\begin{array}{c}-0.02 \\
{[.921]}\end{array}$ & $\begin{array}{c}-0.14 \\
{[.574]}\end{array}$ & $\begin{array}{c}-0.23 \\
{[.506]}\end{array}$ & $\begin{array}{c}\mathbf{0 . 8 3}^{\mathrm{a}} \\
{[.000]}\end{array}$ & $\begin{array}{c}-0.26 \\
{[.396]}\end{array}$ \\
\hline Student & $\begin{array}{c}-0.12 \\
{[.683]}\end{array}$ & $\begin{array}{c}0.12 \\
{[.660]}\end{array}$ & $\begin{array}{c}-0.20 \\
{[.166]}\end{array}$ & $\begin{array}{c}0.03 \\
{[.902]}\end{array}$ & $\begin{array}{c}0.32 \\
{[.195]}\end{array}$ & $\begin{array}{c}-0.06 \\
{[.819]}\end{array}$ & $\begin{array}{c}0.20 \\
{[.420]}\end{array}$ & $\begin{array}{c}-0.35 \\
{[.153]}\end{array}$ & $\begin{array}{c}-0.12 \\
{[.739]}\end{array}$ & $\begin{array}{c}0.06 \\
{[.741]}\end{array}$ & $\begin{array}{c}-0.06 \\
{[.846]}\end{array}$ \\
\hline Homemaker & $\begin{array}{c}-0.14 \\
{[.644]}\end{array}$ & $\begin{array}{c}0.30 \\
{[.263]}\end{array}$ & $\begin{array}{c}0.25 \\
{[.104]}\end{array}$ & $\begin{array}{c}-0.14 \\
{[.567]}\end{array}$ & $\begin{array}{c}0.26 \\
{[.282]}\end{array}$ & $\begin{array}{c}0.30 \\
{[.271]}\end{array}$ & $\begin{array}{c}0.30 \\
{[.224]}\end{array}$ & $\begin{array}{c}0.23 \\
{[.354]}\end{array}$ & $\begin{array}{c}-0.17 \\
{[.642]}\end{array}$ & $\begin{array}{c}0.59^{\mathrm{a}} \\
{[.001]}\end{array}$ & $\begin{array}{c}-0.06 \\
{[.838]}\end{array}$ \\
\hline Unemployed & $\begin{array}{c}0.24 \\
{[.403]}\end{array}$ & $\begin{array}{c}0.62^{b} \\
{[.018]}\end{array}$ & $\begin{array}{c}0.22^{\mathrm{c}} \\
{[.090]}\end{array}$ & $\begin{array}{c}0.49^{b} \\
{[.044]}\end{array}$ & $\begin{array}{c}0.55^{b} \\
{[.020]}\end{array}$ & $\begin{array}{c}0.09 \\
{[.733]}\end{array}$ & $\begin{array}{c}0.08 \\
{[.733]}\end{array}$ & $\begin{array}{c}-0.04 \\
{[.847]}\end{array}$ & $\begin{array}{c}-0.13 \\
{[.701]}\end{array}$ & $\begin{array}{c}0.47^{\mathrm{a}} \\
{[.009]}\end{array}$ & $\begin{array}{c}0.02 \\
{[.937]}\end{array}$ \\
\hline Age & $\begin{array}{c}0.01^{\mathrm{a}} \\
{[.000]}\end{array}$ & $\begin{array}{c}0.01 \\
{[.145]}\end{array}$ & $\begin{array}{c}0.02^{\mathrm{a}} \\
{[.000]}\end{array}$ & $\begin{array}{c}0.00 \\
{[.444]}\end{array}$ & $\begin{array}{c}0^{0.01}{ }^{b} \\
{[.043]}\end{array}$ & $\begin{array}{c}0.00 \\
{[.777]}\end{array}$ & $\begin{array}{c}0.01^{\mathrm{c}} \\
{[.071]}\end{array}$ & $\begin{array}{c}0.01^{\mathrm{a}} \\
{[.004]}\end{array}$ & $\begin{array}{c}0^{0.01}{ }^{\mathrm{a}} \\
{[.002]}\end{array}$ & $\begin{array}{c}0.00 \\
{[.133]}\end{array}$ & $\begin{array}{c}0.02^{\mathrm{a}} \\
{[.000]}\end{array}$ \\
\hline Gender & $\begin{array}{c}0.16^{b} \\
{[.039]}\end{array}$ & $\begin{array}{c}0.08 \\
{[.322]}\end{array}$ & $\begin{array}{c}0.12^{\mathrm{a}} \\
{[.007]}\end{array}$ & $\begin{array}{c}0.05 \\
{[.522]}\end{array}$ & $\begin{array}{c}0.06 \\
{[.446]}\end{array}$ & $\begin{array}{c}-0.02 \\
{[.818]}\end{array}$ & $\begin{array}{c}0.05 \\
{[.409]}\end{array}$ & $\begin{array}{c}-0.09 \\
{[.224]}\end{array}$ & $\begin{array}{c}0.00 \\
{[.974]}\end{array}$ & $\begin{array}{l}-0.11^{b} \\
{[.018]}\end{array}$ & $\begin{array}{c}-0.06 \\
{[.442]}\end{array}$ \\
\hline $\begin{array}{l}\text { Correction } \\
\text { variable }\end{array}$ & $\begin{array}{c}0.22 \\
{[.562]}\end{array}$ & $\begin{array}{c}0.51 \\
{[.206]}\end{array}$ & $\begin{array}{c}0.03 \\
{[.900]}\end{array}$ & $\begin{array}{c}-0.32 \\
{[.293]}\end{array}$ & $\begin{array}{c}0.32 \\
{[.316]}\end{array}$ & $\begin{array}{l}-0.83^{c} \\
{[.077]}\end{array}$ & $\begin{array}{c}0.01 \\
{[.984]}\end{array}$ & $\begin{array}{c}-0.54 \\
{[.269]}\end{array}$ & $\begin{array}{c}0.53 \\
{[.236]}\end{array}$ & $\begin{array}{c}0.59^{\mathrm{a}} \\
{[.000]}\end{array}$ & $\begin{array}{c}-0.33 \\
{[.343]}\end{array}$ \\
\hline
\end{tabular}




\section{A1.1 Correction equation specifications}

The correction equation relates the availability of the observations for all the variables present in the main equation to a set of explanatory variables. The biggest lack of observations in the main equations was due to the missing observations in the corruption perception variable, the frequency of visits to the institutions (see table 2.) and the willingness to give bribe variable. Thus, explanatory variables for the correction equation should be targeted to explain the lack of observations mostly for these three variables. As the explanatory variables I use individual characteristics of the respondents such as age, education and gender. Below I explain why I consider these characteristics to be important.

Arguably, the availability of observations in corruption perception variable depends on the age of the respondents. Very young and very old people are likely not to have a precise idea about corruption ${ }^{11}$. Young people usually do not care about corruption since they did not really had a chance to face it, and old people have usually a lot of problems other than corruption. Their health is getting worse; they have to care for their grandchildren. Old people are often sclerotic. They might not remember what and where they heard about corruption, whether they went to certain organizations during the last twelve months before the survey or not. Old and middle aged people are usually those who still remember the repression of opinions present under the communist regime, and, thus, they might be afraid to answer the questions about corruption. I would expect the association between the availability of observations and age to be bell shaped: both old and very young people seem to have less

\footnotetext{
${ }^{11}$ In fact it proves that he age squared is significant in only four out of eleven cases in correction equation fro corruption perception equation, and in only one case in correction equation for willingness to give bribe equation. Education is much more important factor.
} 
clear idea about corruption. The simplest way to model the bell shape relationship is to include both the age and age squared to the correction equation.

People with higher level of education are likely to think about social issues deeper than those with lower education. More educated people are likely have clearer idea on corruption then people with lower education, unless the latter do some kind business where they have to deal with the officials. It seems necessary to include education to the correction equation as well.

The availability of answers is likely to depend on the gender of the respondent. It is usually so that these are women in Ukraine who to take care of children, who keep the house clean, and who have to solve many practical problems in everyday life. Usually it is women who take children to the doctors, go to the school meetings, conduct payments for the utilities, arrange for the flat repairing, cook, clean and shop. Women, thus, are likely to meet corruption much more often then men and have to have much better formed perception about corruption in the society and the related issues. In addition they usually have a tendency to talk a lot to each other conveying rumors, and all the kinds of happenings. Thus, it is the women who are likely to have more information about corruption, as well as about a lot of other social things, than men.

Summing up what was said above the availability of the answers to the questions present in the main equation seems to depend on age (and squared age), education and gender. Correction equation takes the following form ${ }^{12}$ :

$$
\begin{aligned}
& D_{W G B}=\operatorname{Pr}\left(\alpha_{10} \text { Const }+\alpha_{11} A+\alpha_{12} A^{2}+\alpha_{13} E+\alpha_{14} X\right)+e_{3} \\
& D_{C P}=\operatorname{Pr}\left(\alpha_{20} \text { Const }+\alpha_{21} A+\alpha_{22} A^{2}+\alpha_{23} E+\alpha_{24} X\right)+e_{4}
\end{aligned}
$$

Where 
$\operatorname{Pr}-$ normal probability distribution

Dependent variable $\left(D_{W G B}\right)$ : dummy equal to 0 if no value is missing in all the variables present in the Willingness to Give Bribe equation, and 1 if at least one value is missing Dependent variable $\left(D_{C P}\right)$ : dummy equal to 0 if no value is missing in all the variables present in the Willingness to Give Bribe equation, and 1 if at least one value is missing Independent variables: age $(\mathrm{A})$, age square $\left(\mathrm{A}^{2}\right)$, education $(\mathrm{E})$, gender $(\mathrm{X})$.

I estimate correction equation according to probit methodology.

\section{A1.2 Identification of the main equation with correction equation variable}

There have been big discussions in the literature on whether it is possible to include all the explanatory variables that are present in the correction equation to the main equation. For example Saha et. al. (1997) and Morffatt, Peters (2000) include all of the variables that are in the correction equation to the main equation. Identification of the main equation in this case is assured by the non-linearity of the Mill's ratio.

On the other hand, Puhani (2000) argues that in this case the results are rather unrobust due to collinearity problems. According to him, Mill's ratio in its most commonly used part of it is quasi linear, and, therefore, collinearity problems are likely to prevail. Similarly, Little and Rubin (1987, p. 230) state that for the Heckman method to work it is necessary that some variables that are included to the correction equation are not included to the main equation.

In this paper I include education to the correction equation, while it is not present in the main equation. In the main equation the effect of education is accounted for by inclusion of age and occupation dummies.

\footnotetext{
${ }^{12}$ There are two correction equations of this form: one of them corrects corruption perception equation, the other
} 


\section{A1.3 Correction equations outcome}

Interpretation of the correction equations should take into account the extent to which the independent variables are able to explain the variation of the dependent one. If the explanatory capacity is poor, there is not much sense to speak about the significance of explanatory variables.

From the first sight the explanatory power of the equations seems to be quite strong. The percentage of correct predictions varies from $60 \%$ to $80 \%$ of observations. However when one considers the percentage of zeroes and ones in the whole sample, one might notice that the "naive" explanatory variable, i.e. the variable which would be equal to one if the percentage of ones in the dependent variable is greater than 50 or zero otherwise, would do predict well too. Take, for example, correction equation for the corruption perception equation for the central government (table 13.). The fraction of correct predictions from a complicated model of correction equation is 0.70 . The fraction of zero observations in the dependent variable is also 0.70 . Thus, if instead of using so many regressors I had just used one, which would be equal to zero for all the values of dependent variable, I would obtain the same fit.

So, before describing the results, it is necessary to compare the predictive power of the used regressors with the predictive power of naïve estimates. The detailed description of the test can be found in the appendix 4 . The results of the test are presented in the last two rows of the tables A1-1 and A1-2 of the current appendix. $\chi^{2}$ there and p-value are those of the test. In five out of eleven cases in both correction equations the complicated sets of explanatory variables did not give better prediction than a naïve predictor. Thus, the interpretations below should be taken with care.

- willingness to give bribe equation 
In both correction equations age seems not to be an important determinant of the availability of observations, while education is. People with full higher education are more likely to answer the questions in the main equations. This outcome is not surprising. Welleducated people are usually more thoughtful, and more likely to have an opinion. The surprising fact is that women are less likely to answer, contrary to what was expected. Women in Ukraine are usually those who have to care about all the little things of everyday life. These are usually women who visit school meeting, take children to the doctors, clean the flats, conduct payments for the utilities, cook and shop. Thus, they are more likely to face everyday corruption. Moreover, they are thought by the general population to be more prone to convey rumors and the things that happen in the private life of the others, so they are likely to be more informed about corruption. However, it seems that either it is not the case, or for some reason they are less likely to speak about such matters. On the other hand, men usually more often watch television and read newspapers since they usually have much more time for such activities. Thus, they really might have clearer perception of corruption and related issues than women. 
Table A1-1

Correction equations for corruption perception equations (equation A1-2)

\begin{tabular}{|c|c|c|c|c|c|c|c|c|c|c|c|}
\hline Parameter & $\begin{array}{r}\text { Central } \\
\text { Govt. }\end{array}$ & $\begin{array}{l}\text { Local } \\
\text { Govt. }\end{array}$ & $\begin{array}{l}\text { Juridic. } \\
\text { Instit. }\end{array}$ & $\begin{array}{c}\text { Inspec- } \\
\text { tions }\end{array}$ & Police & Army & $\begin{array}{l}\text { Educat. } \\
\text { Establ. }\end{array}$ & $\begin{array}{l}\text { Medic. } \\
\text { Establ. }\end{array}$ & $\begin{array}{r}\text { State } \\
\text { TV }\end{array}$ & $\begin{array}{l}\text { Privat. } \\
\text { Author. }\end{array}$ & Banks \\
\hline Constant & $\begin{array}{c}-0.25 \\
{[.350]}\end{array}$ & $\begin{array}{l}-0.71^{b} \\
{[.010]}\end{array}$ & $\begin{array}{l}-\mathbf{- 0 . 4 8}{ }^{\mathrm{c}} \\
{[.073]}\end{array}$ & $\begin{array}{c}-0.15 \\
{[.555]}\end{array}$ & $\begin{array}{c}-0.14 \\
{[.585]}\end{array}$ & $\begin{array}{l}-\mathbf{- 0 . 6 4} 4^{b} \\
{[.014]}\end{array}$ & $\begin{array}{l}-\mathbf{0 . 8 4} 4^{\mathrm{a}} \\
{[.004]^{2}}\end{array}$ & $\begin{array}{l}-\mathbf{- 0 . 6 8}{ }^{\mathrm{b}} \\
{[.017]}\end{array}$ & $\begin{array}{c}0.15 \\
{[.562]}\end{array}$ & $\begin{array}{c}-0.15 \\
{[.558]}\end{array}$ & $\begin{array}{c}-0.33 \\
{[.200]}\end{array}$ \\
\hline Age & $\begin{array}{l}-0.01 \\
{[.420]}\end{array}$ & $\begin{array}{c}-0.01 \\
{[.395]}\end{array}$ & $\begin{array}{c}-0.01 \\
{[.540]}\end{array}$ & $\begin{array}{c}-0.01 \\
{[.410]}\end{array}$ & $\begin{array}{c}-0.01 \\
{[.438]}\end{array}$ & $\begin{array}{c}0.00 \\
{[.786]}\end{array}$ & $\begin{array}{l}-0.01 \\
{[.312]}\end{array}$ & $\begin{array}{c}-0.02 \\
{[.122]}\end{array}$ & $\begin{array}{c}0.00 \\
{[.856]}\end{array}$ & \begin{tabular}{|c|}
0.00 \\
{$[.979]$} \\
\end{tabular} & $\begin{array}{c}0.01 \\
{[.301]}\end{array}$ \\
\hline Age square & $\begin{array}{c}0.00 \\
{[.197]}\end{array}$ & $\begin{array}{c}0.00 \\
{[.101]}\end{array}$ & $\begin{array}{c}0.00 \\
{[.138]}\end{array}$ & $\begin{array}{c}0.00^{\mathrm{c}} \\
{[.053]}\end{array}$ & $\begin{array}{c}.0 .00^{b} \\
{[.048]}\end{array}$ & $\begin{array}{c}0.00 \\
{[.217]}\end{array}$ & $\begin{array}{c}0.00^{b} \\
{[.017]}\end{array}$ & $\begin{array}{c}0^{0.00^{b}} \\
{[.021]}\end{array}$ & $\begin{array}{c}0.00 \\
{[.563]}\end{array}$ & $\begin{array}{c}0.00 \\
{[.698]}\end{array}$ & $\begin{array}{c}0.00 \\
{[.766]}\end{array}$ \\
\hline Education 2 & $\begin{array}{l}-\mathbf{0 . 3 3}{ }^{\mathrm{c}} \\
{[.060]}\end{array}$ & $\begin{array}{c}-0.20 \\
{[.256]}\end{array}$ & $\begin{array}{c}-0.28 \\
{[.108]}\end{array}$ & $\begin{array}{c}-0.25 \\
{[.170]}\end{array}$ & $\begin{array}{l}-0.24 \\
{[.181]}\end{array}$ & $\begin{array}{l}-0.19 \\
{[.271]}\end{array}$ & $\begin{array}{l}-0.14 \\
{[.414]}\end{array}$ & $\begin{array}{c}-0.12 \\
{[.481]}\end{array}$ & $\begin{array}{l}-0.13 \\
{[.499]}\end{array}$ & $\begin{array}{l}-0.11 \\
{[.548]}\end{array}$ & $\begin{array}{c}-0.14 \\
{[.423]}\end{array}$ \\
\hline Education 3 & & $\begin{array}{c}-0.19 \\
{[.269]}\end{array}$ & $\begin{array}{c}-0.27 \\
{[.110]}\end{array}$ & & $\begin{array}{l}-0.38^{\mathrm{b}} \\
{[.029]}\end{array}$ & & $\begin{array}{l}-0.29^{c} \\
{[.089]}\end{array}$ & $\begin{array}{c}-0.27 \\
{[.110]}\end{array}$ & & & \\
\hline Education 4 & $\begin{array}{l}-0.68^{\mathrm{a}} \\
{[.003]}\end{array}$ & $\begin{array}{c}-0.34 \\
{[.137]}\end{array}$ & $\begin{array}{c}-0.13 \\
{[.571]}\end{array}$ & $\begin{array}{l}-0.06 \\
{[.796]}\end{array}$ & $\begin{array}{l}-0.10 \\
{[.655]}\end{array}$ & $\begin{array}{l}-0.26 \\
{[.249]}\end{array}$ & $\begin{array}{l}-0.26 \\
{[.271]}\end{array}$ & $\begin{array}{l}-0.52^{b} \\
{[.038]}\end{array}$ & $\begin{array}{l}-0.09 \\
{[.707]}\end{array}$ & $\begin{array}{l}-0.43^{c} \\
{[.053]}\end{array}$ & $\begin{array}{l}-0.36 \\
{[.105]}\end{array}$ \\
\hline Education 5 & & & & & & & $\begin{array}{l}-\mathbf{- 0 . 4 0 ^ { \mathrm { b } }} \\
{[.016]}\end{array}$ & & & & \\
\hline Education 6 & $\begin{array}{l}-0.61^{\mathrm{a}} \\
{[.002]}\end{array}$ & $\begin{array}{l}-0.53^{\mathrm{a}} \\
{[.008]}\end{array}$ & $\begin{array}{l}-0.35^{\mathrm{c}} \\
{[.073]}\end{array}$ & $\begin{array}{l}-0.49^{b} \\
{[.013]}\end{array}$ & $\begin{array}{ll}-0.43^{b} \\
{[.027]} \\
\end{array}$ & $\begin{array}{l}-0.39^{b} \\
{[.042]}\end{array}$ & $\begin{array}{l}-\mathbf{- 0 . 4 4}{ }^{\mathrm{b}} \\
{[.030]}\end{array}$ & $\begin{array}{l}-0.49^{\mathrm{b}} \\
{[.017]}\end{array}$ & $\begin{array}{l}-0.32 \\
{[.107]}\end{array}$ & $\begin{array}{l}-0.59^{\mathrm{a}} \\
{[.002]}\end{array}$ & $\begin{array}{l}-0.38^{b} \\
{[.045]}\end{array}$ \\
\hline Education 7 & & & & $\begin{array}{l}-0.72^{\mathrm{a}} \\
{[.000]}\end{array}$ & $\begin{array}{l}-0.74^{\mathrm{a}} \\
{[.000]}\end{array}$ & & $\begin{array}{l}-\mathbf{- 0 . 6 1} 1^{\mathrm{a}} \\
{[.000]}\end{array}$ & $\begin{array}{l}-0.60^{\mathrm{a}} \\
{[.000]}\end{array}$ & $\begin{array}{l}-0.44^{\mathrm{a}} \\
{[.013]}\end{array}$ & & \\
\hline Education 8 & $\begin{array}{l}-0.76^{\mathrm{a}} \\
{[.001]}\end{array}$ & $\begin{array}{l}-0.49^{b} \\
{[.043]}\end{array}$ & $\begin{array}{l}-0.50^{\mathrm{b}} \\
{[.033]}\end{array}$ & $\begin{array}{l}-0.72^{\mathrm{a}} \\
{[.002]}\end{array}$ & $\begin{array}{l}-0.71^{\mathrm{a}} \\
{[.003]}\end{array}$ & $\begin{array}{l}-0.34 \\
{[.134]}\end{array}$ & $\begin{array}{l}-\mathbf{0 . 6 2} \mathbf{b}^{\mathbf{b}} \\
{[.017]}\end{array}$ & $\begin{array}{l}-0.52^{\mathrm{b}} \\
{[.038]}\end{array}$ & $\begin{array}{l}-\mathbf{C . 4 3}^{\mathrm{c}} \\
{[.067]}\end{array}$ & $\begin{array}{l}-0.49^{\mathbf{b}} \\
{[.030]} \\
\end{array}$ & $\begin{array}{c}-0.34 \\
{[.131]}\end{array}$ \\
\hline Education 9 & $\begin{array}{l}-0.67^{\mathrm{a}} \\
{[.000]}\end{array}$ & $\begin{array}{l}-0.50^{\mathrm{a}} \\
{[.003]}\end{array}$ & $\begin{array}{l}-0.53^{\mathrm{a}} \\
{[.001]}\end{array}$ & $\begin{array}{l}-0.65^{\mathrm{a}} \\
{[.000]}\end{array}$ & $\begin{array}{l}-0.67^{\mathrm{a}} \\
{[.000]}\end{array}$ & $\begin{array}{l}-0.51^{\mathrm{a}} \\
{[.002]}\end{array}$ & $\begin{array}{l}-0.59^{\mathrm{a}} \\
{[.001]}\end{array}$ & $\begin{array}{l}-0.47^{\mathrm{a}} \\
{[.006]}\end{array}$ & $\begin{array}{l}-0.52^{\mathrm{a}} \\
{[.004]}\end{array}$ & $\begin{array}{l}-0.81^{\mathrm{a}} \\
{[.000]}\end{array}$ & $\begin{array}{l}-0.69^{\mathrm{a}} \\
{[.000]}\end{array}$ \\
\hline Gender & $\begin{array}{l}0.21^{\mathrm{a}} \\
{[.001]}\end{array}$ & $\begin{array}{c}0.23^{\mathrm{a}} \\
{[.000]}\end{array}$ & $\begin{array}{c}\mathbf{0 . 1 3}^{\mathrm{b}} \\
{[.037]}\end{array}$ & $\begin{array}{l}0.16^{\mathrm{a}} \\
{[.008]}\end{array}$ & $\begin{array}{c}0.16^{\mathrm{a}} \\
{[.006]}\end{array}$ & $\begin{array}{c}0.30^{\mathrm{a}} \\
{[.000]}\end{array}$ & $\begin{array}{c}0_{0.16}^{b} \\
{[.016]}\end{array}$ & $\begin{array}{c}0.19^{\mathrm{a}} \\
{[.005]}\end{array}$ & $\begin{array}{l}\mathbf{0 . 1 3}^{\mathrm{b}} \\
{[.019]}\end{array}$ & $\begin{array}{l}0.17^{\mathrm{a}} \\
{[.003]}\end{array}$ & $\begin{array}{l}0.14^{\mathrm{b}} \\
{[.016]}\end{array}$ \\
\hline Number of observations & 2097 & 2097 & 2097 & 2097 & 2097 & 2097 & 2097 & 2097 & 2097 & 2097 & 2097 \\
\hline $\mathrm{R}^{2}$ & 0.04 & 0.05 & 0.05 & 0.07 & 0.07 & 0.05 & 0.08 & 0.05 & 0.03 & 0.05 & 0.04 \\
\hline $\begin{array}{l}\text { Fraction of Correct } \\
\text { Predictions }\end{array}$ & 0.70 & 0.77 & 0.73 & 0.65 & 0.64 & 0.65 & 0.80 & 0.81 & 0.60 & 0.64 & 0.60 \\
\hline mean for dep. var. & 0.30 & 0.24 & 0.27 & 0.39 & 0.40 & 0.37 & 0.20 & 0.19 & 0.60 & 0.39 & 0.44 \\
\hline $\begin{array}{l}\chi^{2} \\
\text { P-value }\end{array}$ & $\begin{array}{l}2.31^{13} \\
{[0.12]}\end{array}$ & $\begin{array}{c}1.77 \\
{[0.18]}\end{array}$ & $\begin{array}{c}1.80 \\
{[0.17]}\end{array}$ & $\begin{array}{c}3.02^{\mathrm{c}} \\
{[0.08]}\end{array}$ & $\begin{array}{l}0.12 \\
0.73\end{array}$ & $\begin{array}{l}\text { 8.11 }^{\mathrm{a}} \\
{[0.00]}\end{array}$ & $\begin{array}{l}4.24^{\mathrm{b}} \\
{[0.04]}\end{array}$ & $\begin{array}{c}0.25 \\
{[0.62]}\end{array}$ & $\begin{array}{l}13.28^{\mathrm{a}} \\
{[0.00]}\end{array}$ & $\begin{array}{c}159.67^{\mathrm{a}} \\
{[0.00]}\end{array}$ & $\begin{array}{l}7^{76.44^{\mathrm{a}}} \\
{[0.00]}\end{array}$ \\
\hline
\end{tabular}

P-values are in parenthesis

a - significant on $1 \%$ level

b - significant on $5 \%$ level

c - significant on $10 \%$ level

Dependent variable is equal to one if at least one of the variables present in the main equation contains missing observation and zero otherwise.

\footnotetext{
${ }^{13} \mathrm{H}_{0}: \mathrm{p}_{12}=\mathrm{p}_{21}$, i.e. probits are not better estimates than naive estimates.
} 
Table A1-2

Correction equations for willingness to give bribe equation (equation A1-1)

\begin{tabular}{|c|c|c|c|c|c|c|c|c|c|c|c|}
\hline Institution & $\begin{array}{c}\text { Central } \\
\text { Govt. }\end{array}$ & $\begin{array}{l}\text { Local } \\
\text { Govt. }\end{array}$ & $\begin{array}{l}\text { Juridic. } \\
\text { Instit. }\end{array}$ & $\begin{array}{c}\text { Inspec- } \\
\text { tions }\end{array}$ & Police & Army & $\begin{array}{l}\text { Educat. } \\
\text { Establ. }\end{array}$ & $\begin{array}{l}\text { Medic. } \\
\text { Establ. }\end{array}$ & $\begin{array}{c}\text { State } \\
\text { TV }\end{array}$ & $\begin{array}{l}\text { Privat. } \\
\text { Author. }\end{array}$ & Banks \\
\hline Constant & $\begin{array}{l}-0.44^{\mathrm{c}} \\
{[.099]}\end{array}$ & $\begin{array}{l}-0.75^{\mathrm{a}} \\
{[.006]}\end{array}$ & $\begin{array}{l}-0.60^{b} \\
{[.025]}\end{array}$ & $\begin{array}{l}-0.59^{b} \\
{[.033]}\end{array}$ & $\begin{array}{l}-1.02^{a} \\
{[.000]}\end{array}$ & $\begin{array}{l}-0.73^{a} \\
{[.006]}\end{array}$ & $\begin{array}{l}-0.91^{\mathrm{a}} \\
{[.002]}\end{array}$ & $\begin{array}{l}-0.79^{a} \\
{[.005]}\end{array}$ & $\begin{array}{c}-0.04 \\
{[.877]}\end{array}$ & $\begin{array}{c}-0.24 \\
{[.357]}\end{array}$ & $\begin{array}{c}-0.31 \\
{[.224]}\end{array}$ \\
\hline Age & $\begin{array}{c}0.00 \\
{[.939]}\end{array}$ & $\begin{array}{c}0.00 \\
{[.620]}\end{array}$ & $\begin{array}{c}0.00 \\
{[.851]}\end{array}$ & $\begin{array}{c}0.00 \\
{[.664]}\end{array}$ & $\begin{array}{c}0.00 \\
{[.866]}\end{array}$ & $\begin{array}{c}0.00 \\
{[.617]}\end{array}$ & $\begin{array}{c}0.00 \\
{[.966]}\end{array}$ & $\begin{array}{c}-0.01 \\
{[.588]}\end{array}$ & $\begin{array}{c}0.01 \\
{[.509]}\end{array}$ & $\begin{array}{c}0.01 \\
{[.570]}\end{array}$ & $\begin{array}{c}0.01 \\
{[.228]}\end{array}$ \\
\hline Age square & $\begin{array}{c}0.00 \\
{[.425]}\end{array}$ & $\begin{array}{c}0.00 \\
{[.122]}\end{array}$ & $\begin{array}{c}0.00 \\
{[.373]}\end{array}$ & $\begin{array}{c}0.00^{c} \\
{[.059]}\end{array}$ & $\begin{array}{c}0.00 \\
{[.278]}\end{array}$ & $\begin{array}{c}0.00 \\
{[.496]}\end{array}$ & $\begin{array}{c}0.00 \\
{[.165]}\end{array}$ & $\begin{array}{c}0.00 \\
{[.109]}\end{array}$ & $\begin{array}{c}0.00 \\
{[.880]}\end{array}$ & $\begin{array}{c}0.00 \\
{[.938]}\end{array}$ & $\begin{array}{c}0.00 \\
{[.789]}\end{array}$ \\
\hline Education 2 & $\begin{array}{l}-0.32^{c} \\
{[.066]}\end{array}$ & $\begin{array}{l}-0.31^{c} \\
{[.079]}\end{array}$ & $\begin{array}{l}-0.37^{b} \\
{[.036]}\end{array}$ & $\begin{array}{l}-0.35^{c} \\
{[.052]}\end{array}$ & $\begin{array}{c}-0.24 \\
{[.161]}\end{array}$ & $\begin{array}{c}-0.23 \\
{[.201]}\end{array}$ & $\begin{array}{l}-0.30^{c} \\
{[.088]}\end{array}$ & $\begin{array}{l}-0.28 \\
{[.107]}\end{array}$ & $\begin{array}{l}-0.19 \\
{[.305]}\end{array}$ & $\begin{array}{c}-0.16 \\
{[.362]}\end{array}$ & $\begin{array}{c}-0.26 \\
{[.156]}\end{array}$ \\
\hline Education 3 & $\begin{array}{l}-0.51^{\mathrm{a}} \\
{[.002]}\end{array}$ & $\begin{array}{l}-0.30^{c} \\
{[.072]}\end{array}$ & $\begin{array}{l}-0.39^{b} \\
{[.022]}\end{array}$ & $\begin{array}{l}-0.47^{\mathrm{a}} \\
{[.006]}\end{array}$ & $\begin{array}{l}-0.35^{b} \\
{[.038]}\end{array}$ & $\begin{array}{c}-0.40^{b} \\
{[.019]}\end{array}$ & $\begin{array}{l}-0.46^{a} \\
{[.007]}\end{array}$ & $\begin{array}{l}-0.44^{\mathrm{a}} \\
{[.009]}\end{array}$ & $\begin{array}{c}-0.27 \\
{[.116]}\end{array}$ & $\begin{array}{l}-0.39^{b} \\
{[.021]}\end{array}$ & $\begin{array}{l}-0.33^{c} \\
{[.056]}\end{array}$ \\
\hline Education 4 & $\begin{array}{l}-0.41^{\mathrm{c}} \\
{[.064]}\end{array}$ & $\begin{array}{c}-0.22 \\
{[.338]}\end{array}$ & $\begin{array}{c}-0.11 \\
{[.629]}\end{array}$ & $\begin{array}{c}-0.27 \\
{[.225]}\end{array}$ & $\begin{array}{l}-0.52^{b} \\
{[.027]}\end{array}$ & $\begin{array}{c}-0.23 \\
{[.292]}\end{array}$ & $\begin{array}{c}-0.27 \\
{[.235]}\end{array}$ & $\begin{array}{l}-0.38^{c} \\
{[.099]}\end{array}$ & $\begin{array}{c}-0.04 \\
{[.851]}\end{array}$ & $\begin{array}{c}-0.34 \\
{[.124]}\end{array}$ & $\begin{array}{c}-0.32 \\
{[.152]}\end{array}$ \\
\hline Education 5 & $\begin{array}{l}-0.60^{a} \\
{[.000]}\end{array}$ & $\begin{array}{l}-0.51^{\mathrm{a}} \\
{[.002]}\end{array}$ & $\begin{array}{l}-0.45^{\mathrm{a}} \\
{[.006]}\end{array}$ & $\begin{array}{l}-0.54^{\mathrm{a}} \\
{[.001]}\end{array}$ & $\begin{array}{l}-0.55^{\mathrm{a}} \\
{[.001]}\end{array}$ & $\begin{array}{l}-0.33^{b} \\
{[.043]}\end{array}$ & $\begin{array}{l}-0.56^{\mathrm{a}} \\
{[.001]}\end{array}$ & $\begin{array}{l}-0.58^{a} \\
{[.000]}\end{array}$ & $\begin{array}{l}-0.28^{c} \\
{[.100]}\end{array}$ & $\begin{array}{l}-0.51^{\mathrm{a}} \\
{[.002]}\end{array}$ & $\begin{array}{l}-0.38^{b} \\
{[.024]}\end{array}$ \\
\hline Education 6 & $\begin{array}{l}-0.57^{\mathrm{a}} \\
{[.003]}\end{array}$ & $\begin{array}{l}-0.52^{\mathrm{a}} \\
{[.008]}\end{array}$ & $\begin{array}{l}-0.41^{b} \\
{[.034]}\end{array}$ & $\begin{array}{l}-0.60^{\mathrm{a}} \\
{[.003]}\end{array}$ & $\begin{array}{l}-0.48^{b} \\
{[.015]}\end{array}$ & $\begin{array}{l}-0.39^{b} \\
{[.046]}\end{array}$ & $\begin{array}{l}-0.58^{\mathrm{a}} \\
{[.004]}\end{array}$ & $\begin{array}{l}-0.56^{\mathrm{a}} \\
{[.005]}\end{array}$ & $\begin{array}{c}-0.28 \\
{[.153]}\end{array}$ & $\begin{array}{l}-0.58^{a} \\
{[.003]}\end{array}$ & $\begin{array}{l}-0.44^{b} \\
{[.024]}\end{array}$ \\
\hline Education 7 & $\begin{array}{l}-0.74^{\mathrm{a}} \\
{[.000]}\end{array}$ & $\begin{array}{l}-0.66^{\mathrm{a}} \\
{[.000]}\end{array}$ & $\begin{array}{l}-0.71^{\mathrm{a}} \\
{[.000]}\end{array}$ & $\begin{array}{l}-0.85^{\mathrm{a}} \\
{[.000]}\end{array}$ & $\begin{array}{l}-0.80^{a} \\
{[.000]}\end{array}$ & $\begin{array}{l}-0.54^{\mathrm{a}} \\
{[.001]}\end{array}$ & $\begin{array}{l}-0.75^{\mathrm{a}} \\
{[.000]}\end{array}$ & $\begin{array}{l}-0.73^{a} \\
{[.000]}\end{array}$ & $\begin{array}{l}-0.48^{a} \\
{[.004]}\end{array}$ & $\begin{array}{l}-0.79^{a} \\
{[.000]}\end{array}$ & $\begin{array}{l}-0.67^{\mathrm{a}} \\
{[.000]}\end{array}$ \\
\hline Education 8 & $\begin{array}{l}-0.75^{a} \\
{[.002]}\end{array}$ & $\begin{array}{l}-0.59^{b} \\
{[.015]}\end{array}$ & $\begin{array}{l}-0.72^{\mathrm{a}} \\
{[.003]}\end{array}$ & $\begin{array}{l}-0.77^{\mathrm{a}} \\
{[.002]}\end{array}$ & $\begin{array}{l}-\mathbf{- 0 . 6 8}{ }^{\mathrm{a}} \\
{[.007]}\end{array}$ & $\begin{array}{l}-0.38^{c} \\
{[.096]}\end{array}$ & $\begin{array}{l}-0.74^{\mathrm{a}} \\
{[.004]}\end{array}$ & $\begin{array}{l}-0.59^{b} \\
{[.016]}\end{array}$ & $\begin{array}{c}-0.28 \\
{[.213]}\end{array}$ & $\begin{array}{l}-0.60^{a} \\
{[.009]}\end{array}$ & $\begin{array}{l}-0.41^{\mathrm{c}} \\
{[.071]}\end{array}$ \\
\hline Education 9 & $\begin{array}{l}-0.65^{\mathrm{a}} \\
{[.000]}\end{array}$ & $\begin{array}{l}-0.61^{\mathrm{a}} \\
{[.000]}\end{array}$ & $\begin{array}{l}-0.61^{a} \\
{[.000]}\end{array}$ & $\begin{array}{l}-0.84^{a} \\
{[.000]}\end{array}$ & $\begin{array}{l}-0.75^{\mathrm{a}} \\
{[.000]}\end{array}$ & $\begin{array}{l}-0.57^{\mathrm{a}} \\
{[.001]}\end{array}$ & $\begin{array}{l}-0.78^{a} \\
{[.000]}\end{array}$ & $\begin{array}{l}-0.66^{a} \\
{[.000]}\end{array}$ & $\begin{array}{c}-0.59^{a} \\
{[.001]}\end{array}$ & $\begin{array}{r}\mathbf{- 0 . 8 9} \\
{[.000]} \\
\end{array}$ & $\begin{array}{c}-0.76^{\mathrm{a}} \\
{[.000]}\end{array}$ \\
\hline Gender & $\begin{array}{c}0.22^{\mathrm{a}} \\
{[.000]}\end{array}$ & $\begin{array}{c}0.25^{\mathrm{a}} \\
{[.000]}\end{array}$ & $\begin{array}{c}0.15^{b} \\
{[.013]}\end{array}$ & $\begin{array}{c}0.20^{\mathrm{a}} \\
{[.001]}\end{array}$ & $\begin{array}{c}0.29^{\mathrm{a}} \\
{[.000]}\end{array}$ & $\begin{array}{c}0.28^{\mathrm{a}} \\
{[.000]}\end{array}$ & $\begin{array}{c}0.20^{\mathrm{a}} \\
{[.003]}\end{array}$ & $\begin{array}{c}0.24^{\mathrm{a}} \\
{[.000]}\end{array}$ & $\begin{array}{c}0.09 \\
{[.133]}\end{array}$ & $\begin{array}{c}0.19^{\mathrm{a}} \\
{[.001]}\end{array}$ & $\begin{array}{c}0.14^{b} \\
{[.017]}\end{array}$ \\
\hline Number of observations & 2097 & 2097 & 2097 & 2097 & 2097 & 2097 & 2097 & 2097 & 2097 & 2097 & 2097 \\
\hline $\mathrm{R}^{2}$ & 0.046 & 0.06 & 0.05 & 0.06 & 0.06 & 0.06 & 0.09 & 0.08 & 0.03 & 0.06 & 0.05 \\
\hline $\begin{array}{l}\text { Fraction of Correct } \\
\text { Predictions }\end{array}$ & 0.70 & 0.75 & 0.71 & 0.68 & 0.68 & 0.65 & 0.78 & 0.76 & 0.57 & 0.64 & 0.60 \\
\hline Mean of dep. var. & 0.32 & 0.26 & 0.30 & 0.34 & 0.35 & 0.38 & 0.22 & 0.25 & 0.49 & 0.39 & 0.44 \\
\hline $\begin{array}{l}\chi^{2} \\
\text { P-value }\end{array}$ & $\begin{array}{l}3.31^{\mathrm{c}} \\
{[0.07]}\end{array}$ & $\begin{array}{c}0.29 \\
{[0.58]}\end{array}$ & $\begin{array}{c}1.38 \\
{[0.23]}\end{array}$ & $\begin{array}{c}8.68^{\mathrm{a}} \\
{[0.00]}\end{array}$ & $\begin{array}{c}0.62 \\
{[0.42]}\end{array}$ & $\begin{array}{l}13.56^{\mathrm{a}} \\
{[0.00]}\end{array}$ & $\begin{array}{c}2.51 \\
{[0.11]}\end{array}$ & $\begin{array}{c}1.51 \\
{[0.21]}\end{array}$ & $\begin{array}{l}37.29^{\mathrm{a}} \\
{[0.00]}\end{array}$ & $\begin{array}{c}157.13^{\mathrm{a}} \\
{[0.00]}\end{array}$ & $\begin{array}{l}74.37^{\mathrm{a}} \\
{[0.00]}\end{array}$ \\
\hline
\end{tabular}

$\mathrm{P}$-values are in parenthesis

a - significant on $1 \%$ level

b - significant on $5 \%$ level

c - significant on $10 \%$ level

Dependent variable is equal to one if at least one of the variables present in the main equation contains missing observation and zero otherwise. 


\section{Appendix 2}

\section{A2.1 Method of estimation}

Since the data are mostly of categorical nature the linear regressions might not be the best choice. The most widely used approach in this case is to use logit or probit estimations. Both of the techniques usually provide similar results, but I prefer to use probit it will allow me better comparison of the equation-by-equation estimates with the simultaneous equations estimates (it is very difficult to run simultaneous ordered logits since bivariate probability distribution approximation function is difficult to obtain). Probit approach models the probability of the categorical variable falling into a certain category using normal distribution, which is easier to approximate for the bivariate case.

\section{A2.2 Some technical details of joint probits programming and estimation}

Let $Y_{1}$ and $Y_{2}$ be the dependent variables for the equations one and two

Let $Q_{1}$ be unobserved variable equal to

$Q_{1}=X_{1} B_{1}+U_{1}$

where

$X_{1}$ is the vector of independent variables in the equation one

$B_{1}$ is the vector of coefficients in the equation one

$U_{l}$ is the vector of disturbances in equation one

and 


$$
\begin{array}{cl}
Y_{1}=1 \text { for } \quad Q_{1} \leq 0 & \left(\begin{array}{c}
\left.U_{1} \leq-X_{1} B_{1}\right) \\
2 \text { for } 0<Q_{1} \leq A_{1}
\end{array}\right. \\
\begin{array}{l}
\text { for } A_{1}<Q_{1} \leq A_{2} \\
\text { f for } A_{2}<Q_{1} \leq A_{3}
\end{array} & \left(\begin{array}{r}
\left.-X_{1} B_{1}<U_{1} \leq A_{1}-X_{1} B_{1}\right) \\
\text { 5 for } \left.A_{3}<Q_{1}<U_{1} \leq A_{2}-X_{1} B_{1}\right)
\end{array}\right. \\
\text { f } \left.X_{1} B_{1}<U_{1} \leq A_{3}-X_{1} B_{1}\right)
\end{array}
$$

Let $Q_{2}$ be unobserved variable such that

$$
Q_{2}=X_{2} B_{2}+U_{2}
$$

where $X_{2}$ is the vector of independent variables in the equation two $B_{2}$ is the vector of coefficients in the equation two $U_{2}$ is the vector of disturbances in equation two and

$$
\begin{array}{cc}
Y_{2}=1 \text { for } \quad Q_{2} \leq 0 & \left(\begin{array}{c}
\left.U_{2} \leq-X_{2} B_{2}\right) \\
2 \text { for } 0<Q_{2} \leq C_{1}
\end{array}\right. \\
3 \text { for } C_{1}<Q_{2} \leq C_{2} & \left(\begin{array}{r}
\left.-X_{2} B_{2}<U_{2} \leq C_{1}-X_{2} B_{2}\right) \\
4 \text { for } C_{2}<Q_{2} \leq C_{3}
\end{array}\right. \\
\left.5 \text { for } C_{3}<X_{2} B_{2}<U_{2} \leq C_{2}-X_{2} B_{2}\right) \\
\text { ( } \left.C_{2}-X_{2} B_{2}<U_{2} \leq C_{3}-X_{2} B_{2}\right) \\
\left.C_{3}-X_{2} B_{2}<U_{2}\right)
\end{array}
$$

I use the approximation for the bivariate cumulative normal distribution from the book of Abramovitz and Stegun, (Handbook of Mathematical Functions, formula 26.3.29).

bivariate probability $\left(Y_{1}, Y_{2}\right)=\operatorname{cnorm}\left(X_{1} B_{1}\right) * \operatorname{cnorm}\left(X_{2} B_{2}\right)+\operatorname{norm}\left(X_{1} B_{1}\right) * \operatorname{norm}\left(X_{2} B_{2}\right) *(\rho+$ 
$\left.\rho^{2} * X_{1} B_{1} * X_{2} B_{2} / 2+\rho^{3} *\left(X_{1} B_{1}^{2}-1\right) *\left(X_{2} B_{2}^{2}-1\right) / 6\right) ;$

where cnorm is cumulative normal distribution

norm is normal density function

For this approximation in the Taylor expansions for small correlation coefficient $(\rho)$, the average absolute error for $\rho=0.9$ is 0.00887 , and it is much smaller for smaller $\rho$.

I construct the likelihood function and conduct maximization. For the starting values I use the outcomes of the equation-by-equation estimates. For the correlation coefficient $\rho$ I tried all possible starting values from 0.9 to -0.9 with step 0.1 . 


\section{Appendix 3}

The detailed description of the survey questions, which served as a basis for the variables used in the papers

The following appendix provide the description of the variables used relating them to the actual questions of the questionnaire. I start each section with the original question of the questionnaire that relates to the variable I use. In the footnote I provide the original Ukrainian wording of the question. Then I describe possible answers from which the respondents had to choose and state the type of the variable that comes out.

\section{A3.1 Corruption perception}

To what extend is corruption spread in the following organizations (for the list of the organizations see the table 2)? ${ }^{14}$ The answer to this question represents corruption perception of the respondent in the corresponding institution. Thus, I call this variable "corruption perception". This is categorical variable that varies from one to five according to the following scheme

I. an institution is not corrupt at all

II. it is more likely that it is not corrupt than corrupt

III. one can face corruptness of officials in approximately as many cases as noncorruptness

IV. an institution is likely to be corrupt

V. an institution is heavily corrupt. 


\section{A3.2 Frequency of visits to the organizations}

How many times did you visit the organizations (see the table 2.) during the twelve months before the survey? ${ }^{15}$ The answers to this question provide me with frequency of visits variable, which is categorical and varies from one to four. The categories are:

1 - never visited,

2 - visited one or two times,

3 - visited more than two but less then 10 times,

4 - visited more than ten times.

\section{A3.3 Sources of information about corruption the respondents used}

From which sources did you get the information about corruption during the last twelve months $?^{16}$ Suggested sources are press, TV, radio, friends, strangers, and personal experience.

\section{A3.4 Trust to the mass media variable}

Do you think that the information in the mass media about corruption truthful? ${ }^{17}$ This is categorical variable ranging from one to five. One corresponds to the answer that the information is very truthful, two - rather truthful, three - sometimes truthful sometimes not, four - rather untruthful, five - totally untruthful

\footnotetext{
${ }^{14}$ The original wording in Ukrainian: Як Ви вважаєте, якою мірою хабарництво, продажність поширені серед посадових осіб в органах та організаціях, які я називатиму?

15 The original wording in Ukrainian: Зараз я називатиму органи та організації, а Ви, будь ласка, скажіть, користуючись карткою, скільки приблизно разів за останній рік (останні 12 місяців) Ви ЗВЕРТАЛИСЯ до кожного з них.

163 яких джерел Ви отримували відомості про хабарництво, продажність посадових осіб впродовж останнього року (останніх 12 місяців)?
} 


\section{A3.5 Perceived willingness of the government to fight corruption}

Do you agree that the government does not do anything to fight corruption? ${ }^{18}$ This is categorical variable that varies from one to five (1 - agree, 5 - disagree)

\section{A3.6 Perceived willingness of the population to give bribes}

Do you agree that in order to solve the matter with the public official it is not necessary to give a bribe $?^{19}$ This is categorical variable that varies from one to five (1 - agree, 5 disagree)

There are also some occupation and town size variables. The wordings of questions for them are quite obvious, so I do not describe them in this section. For a brief look at the variables used in the econometric analysis see table 3.

\footnotetext{
17 Як Ви вважаєте, наскільки є достовірною інформація про хабарництво, продажність посадових осіб, яка з'являється на радіо, телебаченні, в пресі?

${ }^{18}$ А зараз я зачитаю Вам кілька тверджень, а Ви, будь ласка, скажіть про кожне з них якою мірою Ви погоджуєтесь або не погоджуєтесь 3 ним: Влада не вживає ніяких заходів для боротьби з хабарництвом

${ }^{19}$ А зараз я зачитаю Вам кілька тверджень, а Ви, будь ласка, скажіть про кожне з них якою мірою Ви погоджуєтесь або не погоджуєтесь 3 ним:

Для успішного вирішення питань $з$ посадовими особами зовсім необов'язково давати хабаря
} 


\section{Appendix 4}

\section{Testing the significance of prediction accuracy in discrete choice models}

The test was suggested by Jaromir Antoch and Jan Hanousek in their paper "A specification test for discrete choice models". The idea is to compare the prediction accuracy of the model in question and a naïve predictor.A naïve predictor is a predictor equal to one for all the values of dependent variable if the number of ones in the dependent variable is more than $50 \%$ of the sample and zero otherwise.

Let $\mathrm{n}_{1}$ be the number of observations which method one predicts correctly and method two predicts incorrectly. Let $\mathrm{n}_{2}$ be the number of observations which method one predicts incorrectly and method two predicts correctly. Then the following statistics has $\chi^{2}$ distribution with one degree of freedom.

$$
\chi^{2}=\left(n_{1}-n_{2}\right)^{2} /\left(n_{1}+n_{2}\right)
$$

The actual values for this statistics are presented in appendix 1 in the last but one row of the tables A1-1 and A1-2. The last row contains he P-values. 